\title{
MOMIR H. POLENAKOVIC - FOUNDER OF THE NEPHROLOGY ASSOCIATIONS IN THE REPUBLIC OF MACEDONIA
}

OFFICIAL ADDRESS OF PROF. GOCE SPASOVSKI, PRESIDENT OF THE MACEDONIAN SOCIETY OF NEPHROLOGY, DIALYSIS, TRANSPLANTATION AND ARTIFICIAL ORGANS (MSNDTAO) AND PROF. OLIVERA STOJCEVA TANEVA, VICE DEAN OF THE MEDICAL FACULTY IN SKOPJE AND SECRETARY GENERAL OF THE MSNDTAO

\section{Goce Spasovski and Olivera Stojceva-Taneva}

Medical Faculty, Ss. Cyril and Methodius University, Skopje, R. Macedonia

Corresponding Author: Goce Spasovski, Department of Nephrology, Medical Faculty Skopje, Vodnjanska 17, Skopje, R. Macedonia
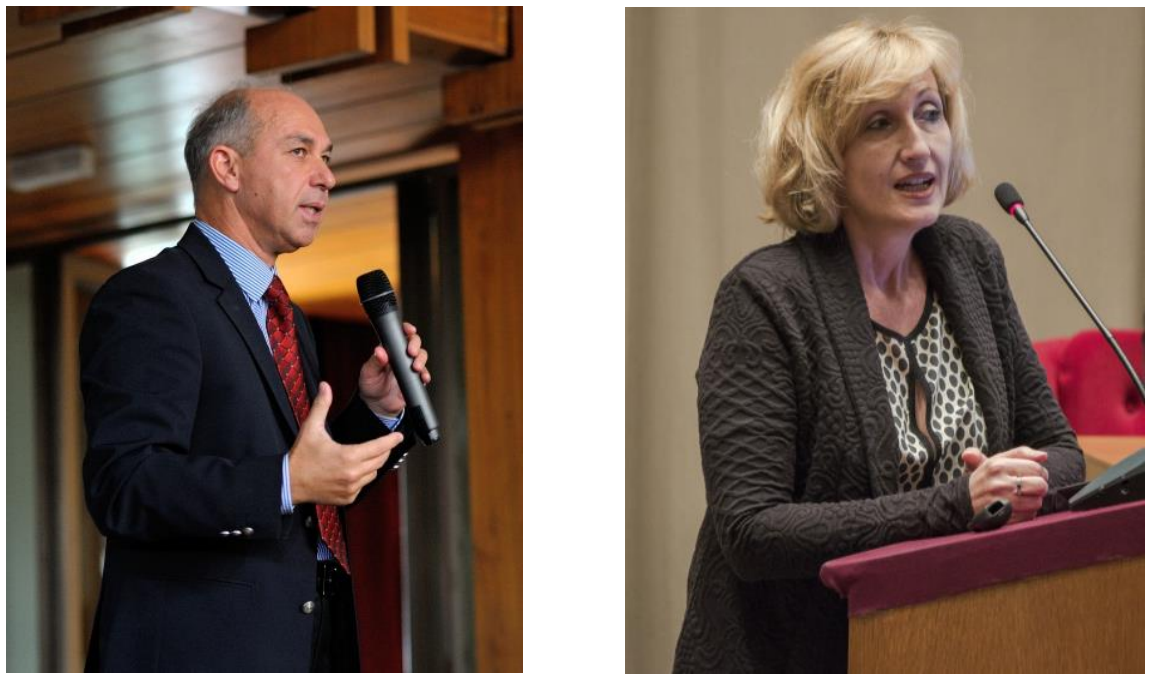

\begin{abstract}
Acad. Momir Polenakovic has devoted his life and work in the diagnosis and treatment of kidney patients, as well as in research of kidney disease. The great experience he has acquired in the work with kidney patients, and after the visit to the most renowned nephrology centers in Europe and the world, he has transferred it to his colleagues through the work in the medical and nephrology associations. The work of the associations was in fact a successful education of young doctors and specialists. Among his most distinguished positions, we can mention: President of the Macedonian Medical Association, founder and President of the MSNDTAO, President of the Yugoslav Society of Nephrology, founder and President of BANTAO, as well as member of the Boards of ESAO and ERA-EDTA. He has received a lot of recognitions for his work achievements.
\end{abstract}

Key words: medical association, nephrology association

Since his student period Acad. M. Polenakovic was involved in the establishment of student relations between the Student Association of the Medical Faculty in Skopje and other student associations of medical faculties in Europe.
In the period of 1958-63 he was a member and Head of the International Cooperation Department of the Student Association of the Medical Faculty in Skopje. During that time he organized an exchange of a number of students 
from the Republic of Macedonia with western European countries. He, himself visited Berlin for two months in 1961 and Poland (Warsaw, Lublin and Gdansk) in 1962, making a good connection with the students of the medical faculties in those cities. In the period 1967-1975 he spent several months in London, at the Guy's Hospital renal unit working with Prof. J.S. Cameron and at the Hammersmith Hospital, where he met distinguished UK nephrologists.

In 1970, Acad. Momir Polenakovic together with Prof. Hrisoho founded the Macedonian Nephrology Society of the Macedonian Medical Association, and he was elected a Secretary of the Society. Later, he was elected a President of the Society and was involved in the creation of the Yugoslav Nephrology Association established in 1975 in Nis, Serbia.

As a specialist in internal medicine and subspecialist in nephrology he communicated with the colleagues from other centers of for- mer Yugoslavia and France, Italy, Germany, Austria and other European countries creating a nephrology network.

In 1972 he spent a year in Chicago, at the Northwestern University, where he met a number of famous American nephrologists. He was invited at that time to visit and to give lectures at the University of California, Los Angeles (UCLA), the University of San Diego - Scripps Clinic, the Harvard Medical School and the National Institute of Health (NIH).

In 1977 he was one of the organizers of the First Scientific Meeting of Yugoslav Nephrologists in Struga with international participation. M. Polenakovic and his colleagues gathered the world renowned nephrologists, among them: J.S. Cameron (UK), P. Ivanovich (USA), M. Burg (USA), JL. Funck-Brentano (France), R. Kluthe (Germany), A. Puhlev (Bulgaria) along with the leading nephrologists from former Yugoslavia.

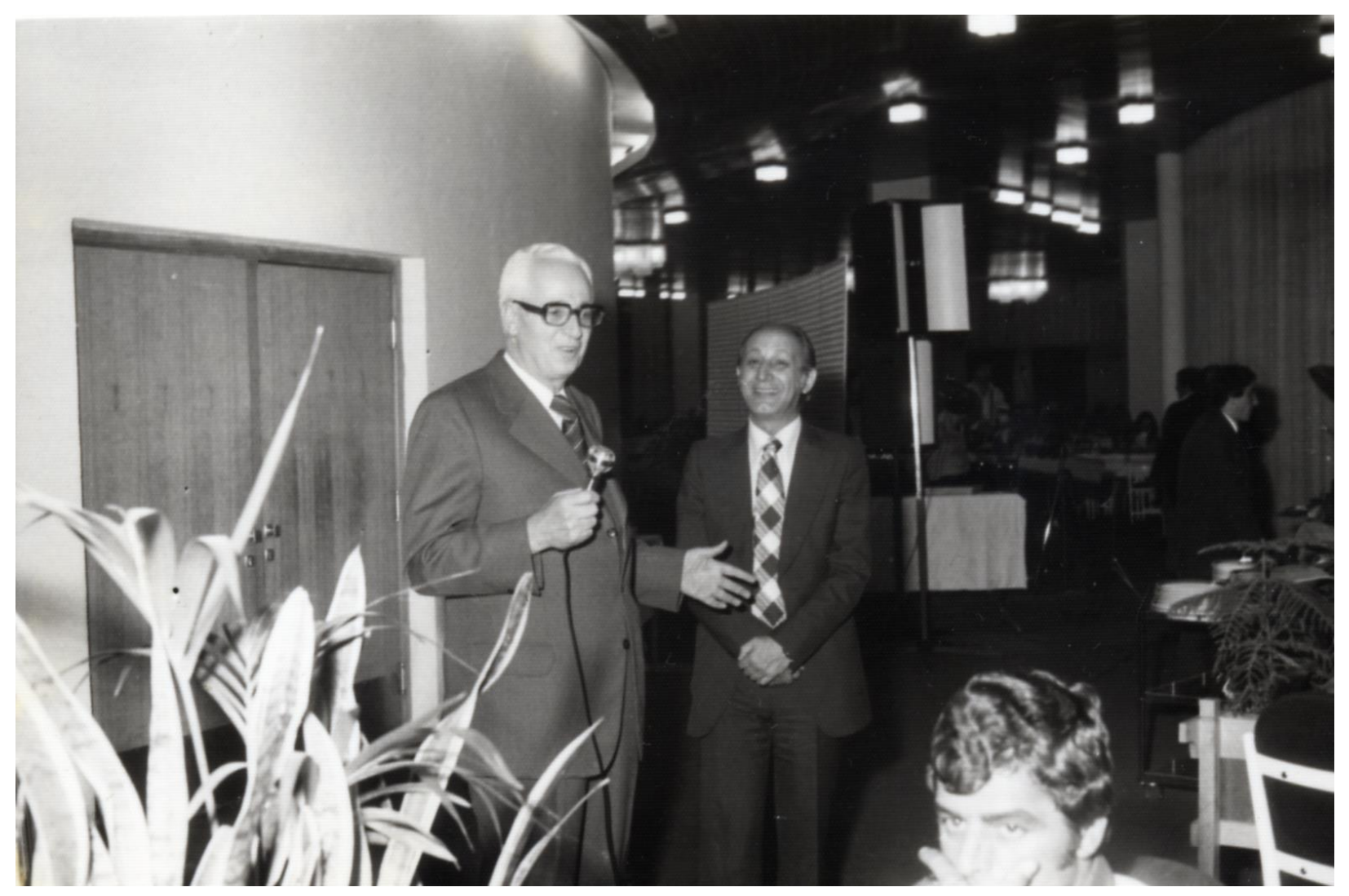

Fig. 1 - V. Danilovic (Belgrade) and D. Hrisoho (Skopje),

First Scientific Meeting of Yugoslav Nephrologists in Struga with international participation, 1977 


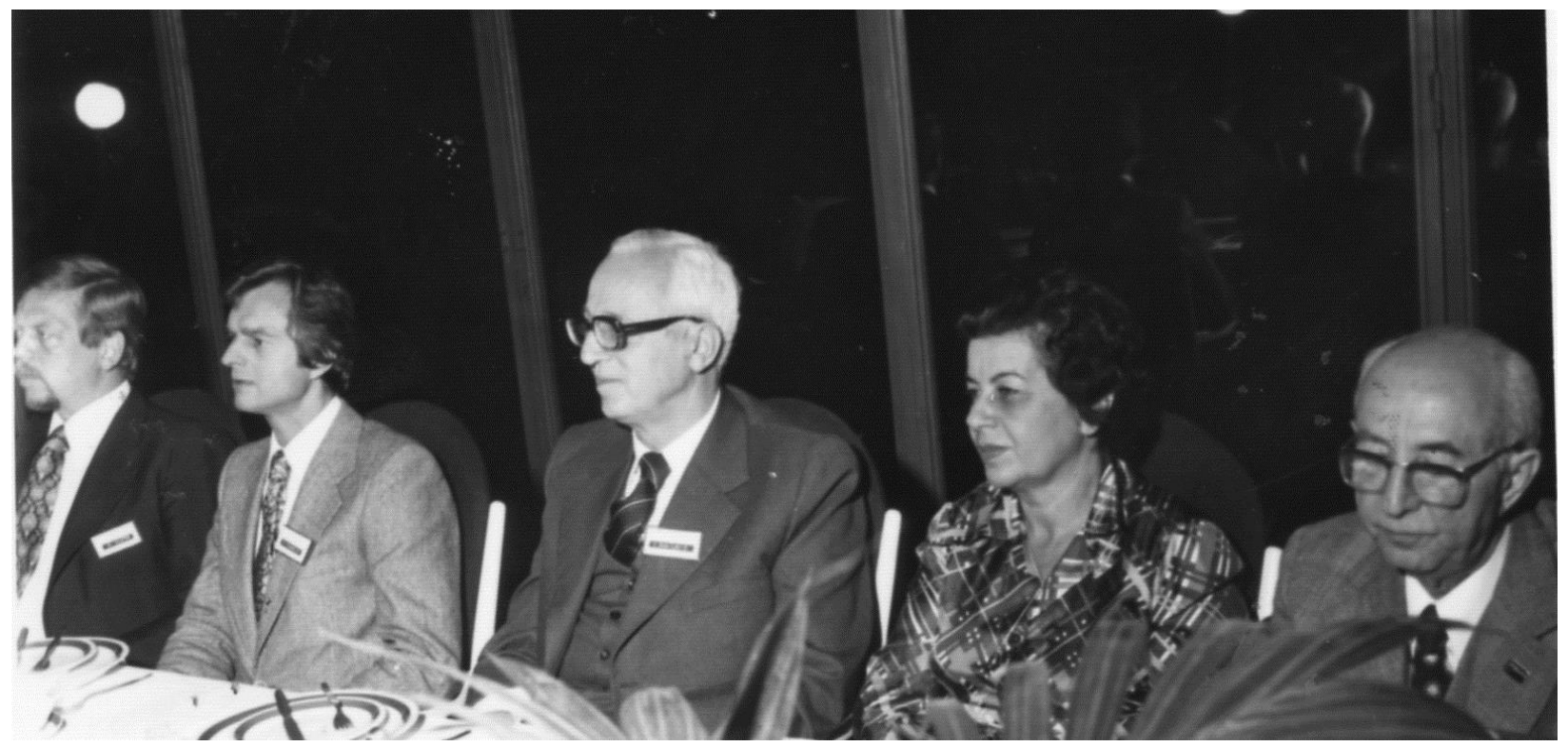

Fig. 2 - From left to right: R. Kluthe (Germany), P. Ivanovich (USA), V. Danilovic (Serbia), V. Calic (Serbia), A. Puhlev (Bulgaria)

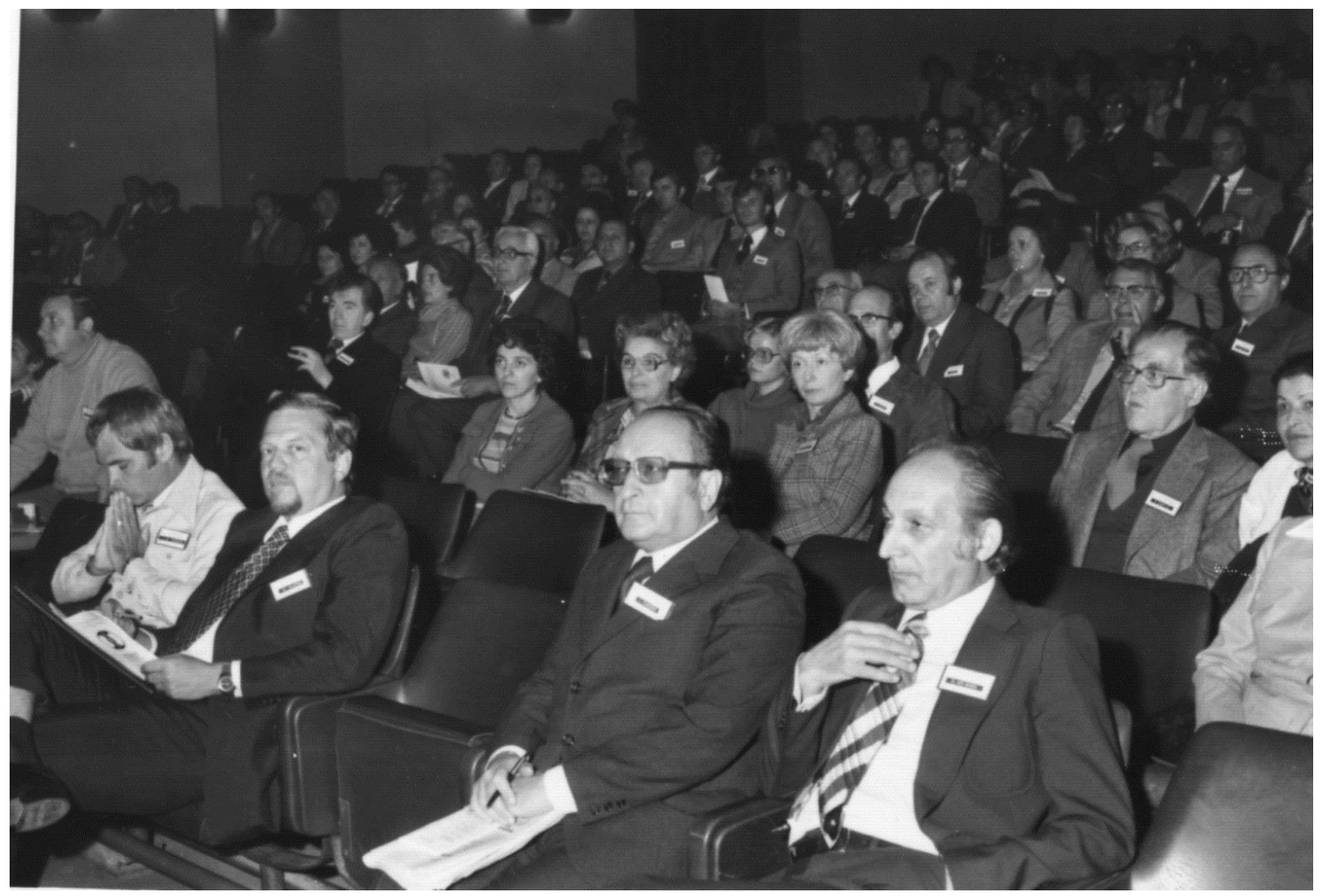

Fig. 3 - From left to right: J.S. Cameron (UK), R. Kluthe (Germany), I. Tazdzer (Republic of Macedonia), D. Hrisoho (Republic of Macedonia) 


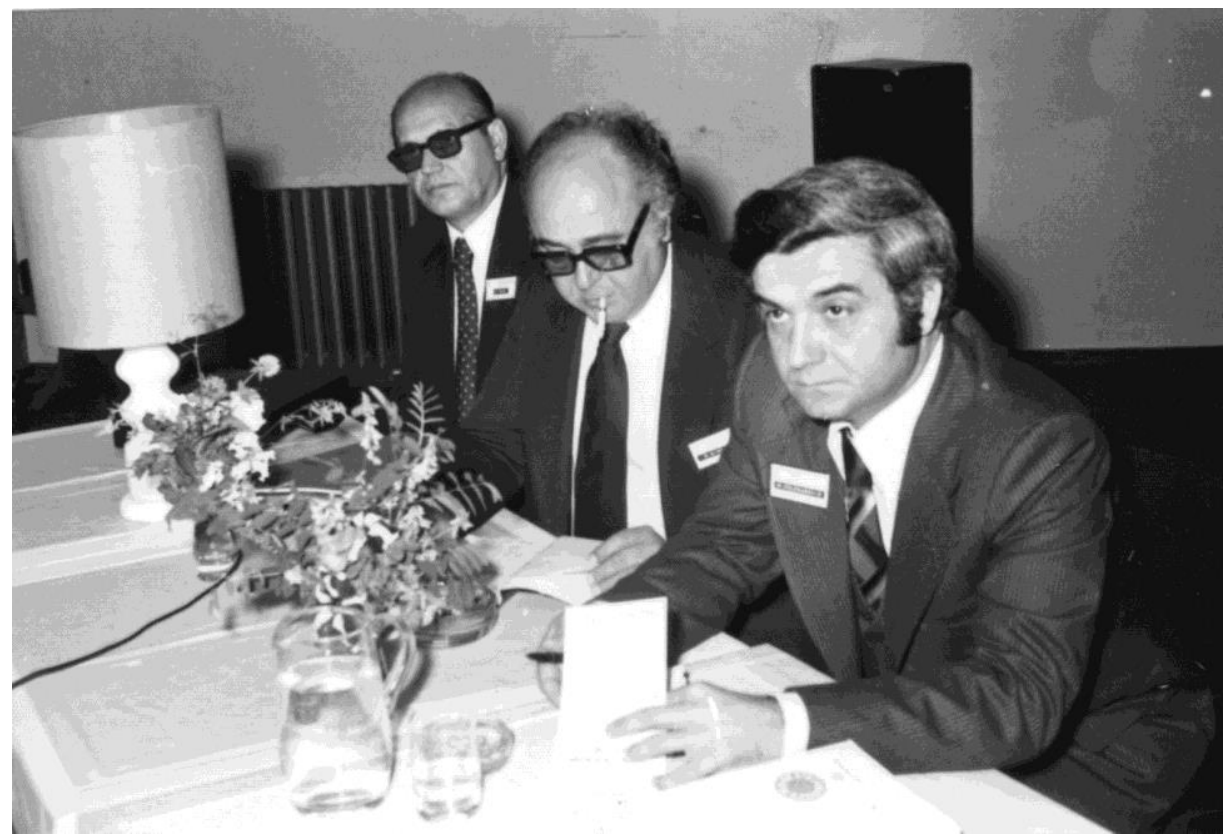

Fig. 4 - From left to right: S. Susa (Serbia), M. Sindzic (Serbia), M. Polenakovic (Republic of Macedonia)

The papers presented at the meeting were published in the Proceedings of the Meeting.

The First Scientific Meeting of Yugoslav Nephrologists in Struga with international participation was very important for the development of nephrology in former Yugoslavia, especially in Skopje and the Republic of Macedonia. The meeting was an entrance of Yugoslav nephrology to Europe and the world.
Professor Polenakovic was very active also in the Republic of Macedonia, participating and organizing the national congresses and meetings of the Macedonian Medical Association. His activities were recognized and in the period 1984-1986 he was elected a President of the Macedonian Medical Association.

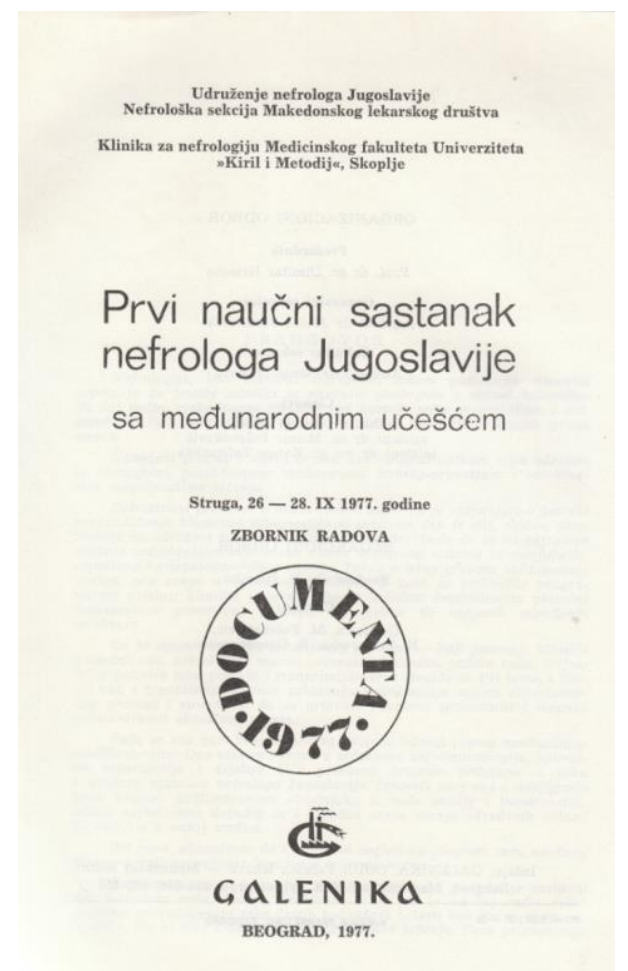

Fig. 5 - Proceedings of the First Scientific Meeting of Yugoslav Nephrologists in Struga with international participation 
Furthermore, he supported the development of immunology at the Medical Faculty in Skopje and in the Republic of Macedonia and as recognition of his activities and participation

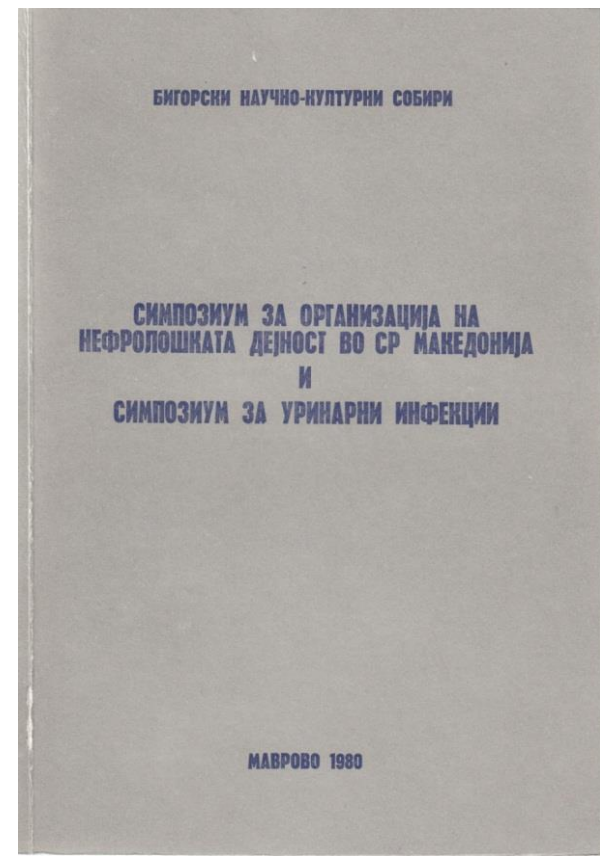

Fig. 6 - Proceedings of the Bigorski Meeting (left), Mavrovo, 1980, and Proceedings from the Meeting on noninvasive diagnosis of renal disease and renal osteodystrophy, Ohrid 23 and 24 April 1987

In the period 1985-1989 he was elected a President of the Yugoslav Society of Nephrology. The fourth and last congress of the Yugoslav Society of Nephrology was held in Skopje in 1989. The papers from the congress were published in the journal Macedonian Me- in several meetings of immunology he was elected a President of the Macedonian Society for Basic, Clinical Immunology and Allergology in the period 1992-1996.

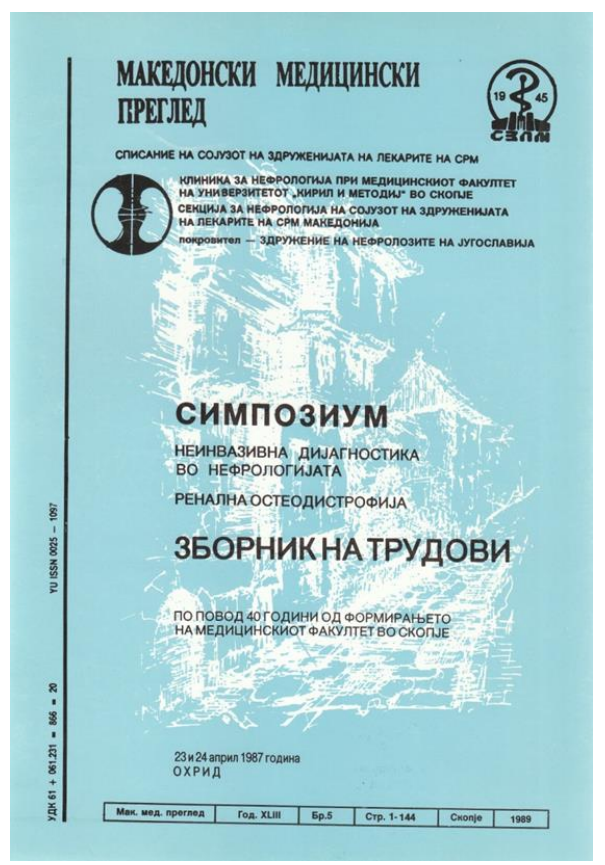

dical Review. The Congress was a great success with participation of renowned experts from Europe and the USA, such as: S. Massry (USA), Horst Klinkmann (Germany), F. Kokot (Poland), A. Davidson (UK), P. Lesavre (France), et al.

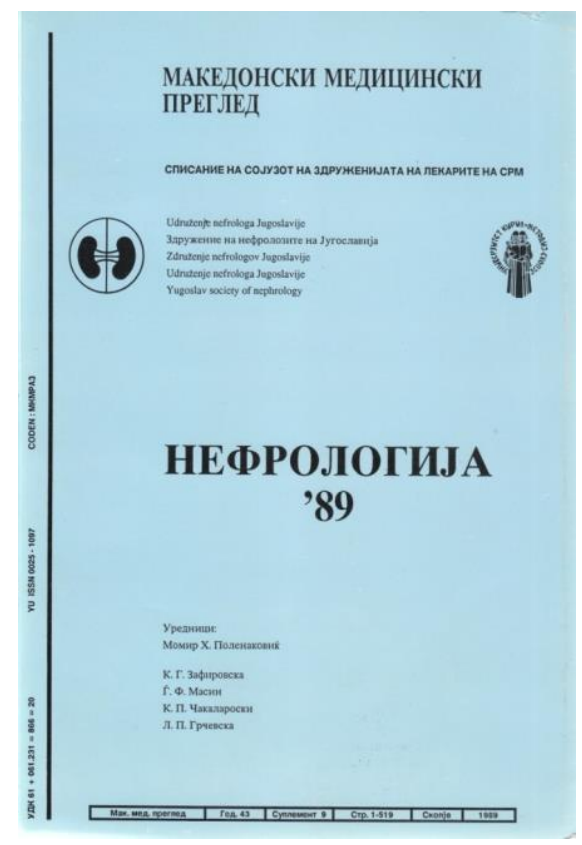

Fig. 7 - Proceedings of the fourth and last congress of the Yugoslav Society of Nephrology 
The activities of M. Polenakovic were acknowledged with his election for Council Member of the ERA-EDTA (ex-officio) in the period 1989-1991.

The nephrology in former Yugoslavia was well developed and was acknowledged by the ERA-EDTA. Having in mind the achievements of the nephrologists and their activities, ERA-EDTA devoted its XXVIII Congress to
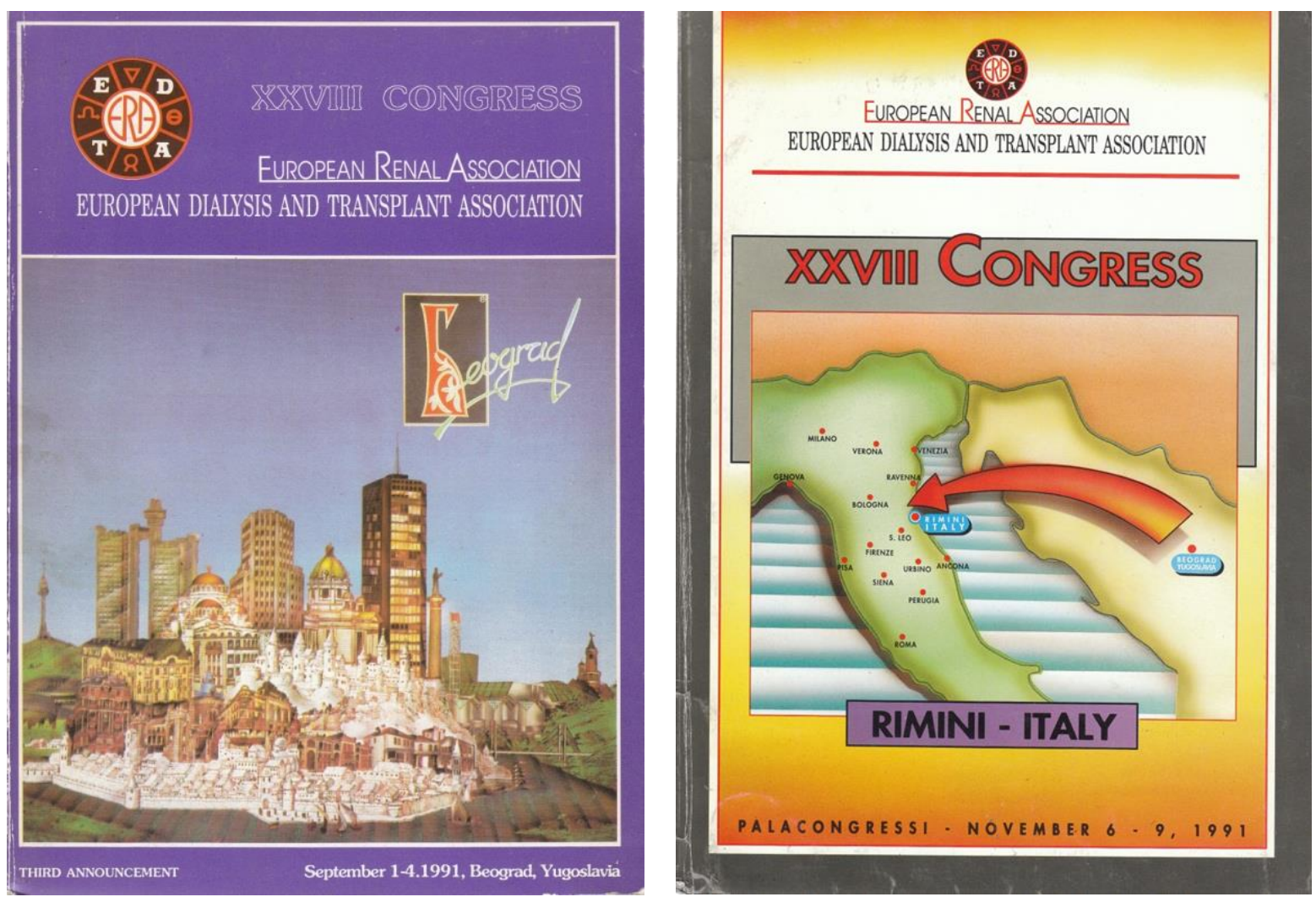

the colleagues from the Yugoslav Society of Nephrology. All was prepared for the Congress to be held from 1-4 September 1991 in Belgrade. President of the Congress was V. Petronjic and Secretary General was M. Polenakovic. Unfortunately, due to the bloody war, $\mathrm{Yu}$ goslavia was broken apart and the Congress was moved to Rimini in Italy, 6-9 November 1991.

Fig. 8 - Announcements of the Congress in Belgrade and in Rimini 


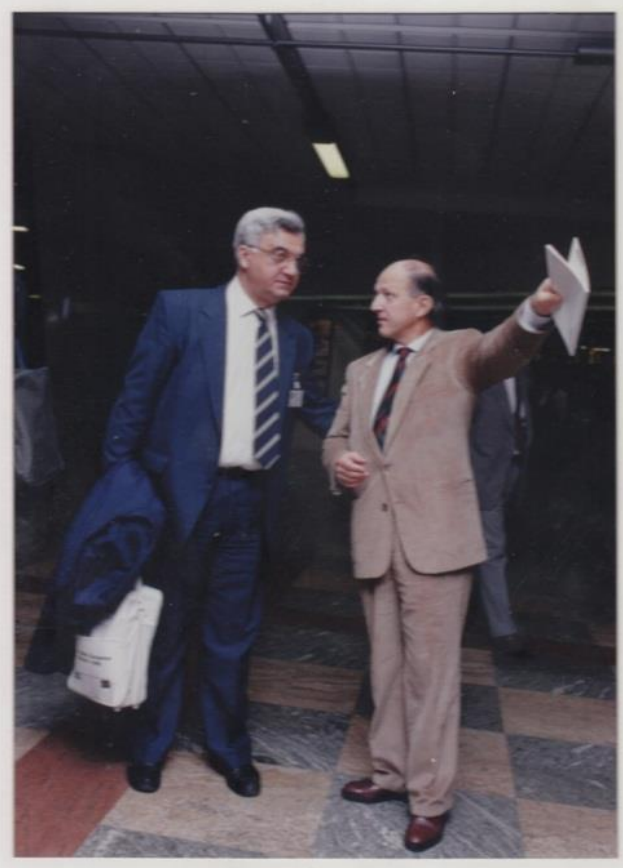

XXVIIIth Congress of the European Renal Association BUROPBAN DIALYSIS AND TRANSPLANT ASSOCIATION RIMINI - TALY - NOVEMBRE 6/9, 1991 - PALACONGRESSI

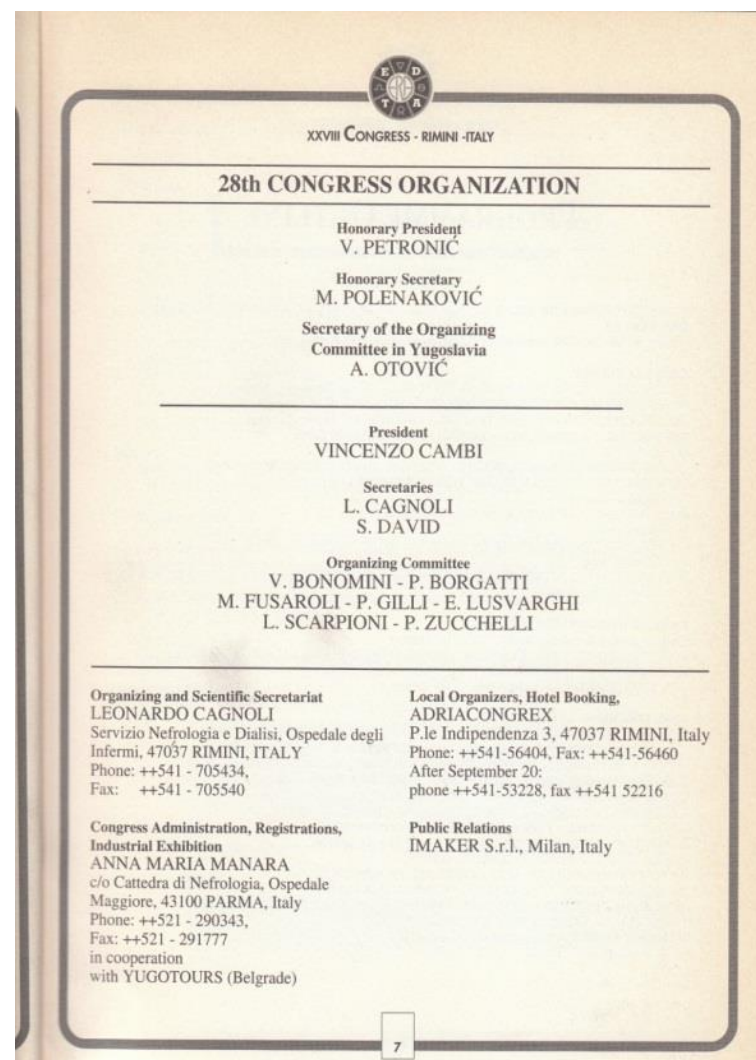

Fig. 9 - M. Polenakovic and V. Cambi (left)

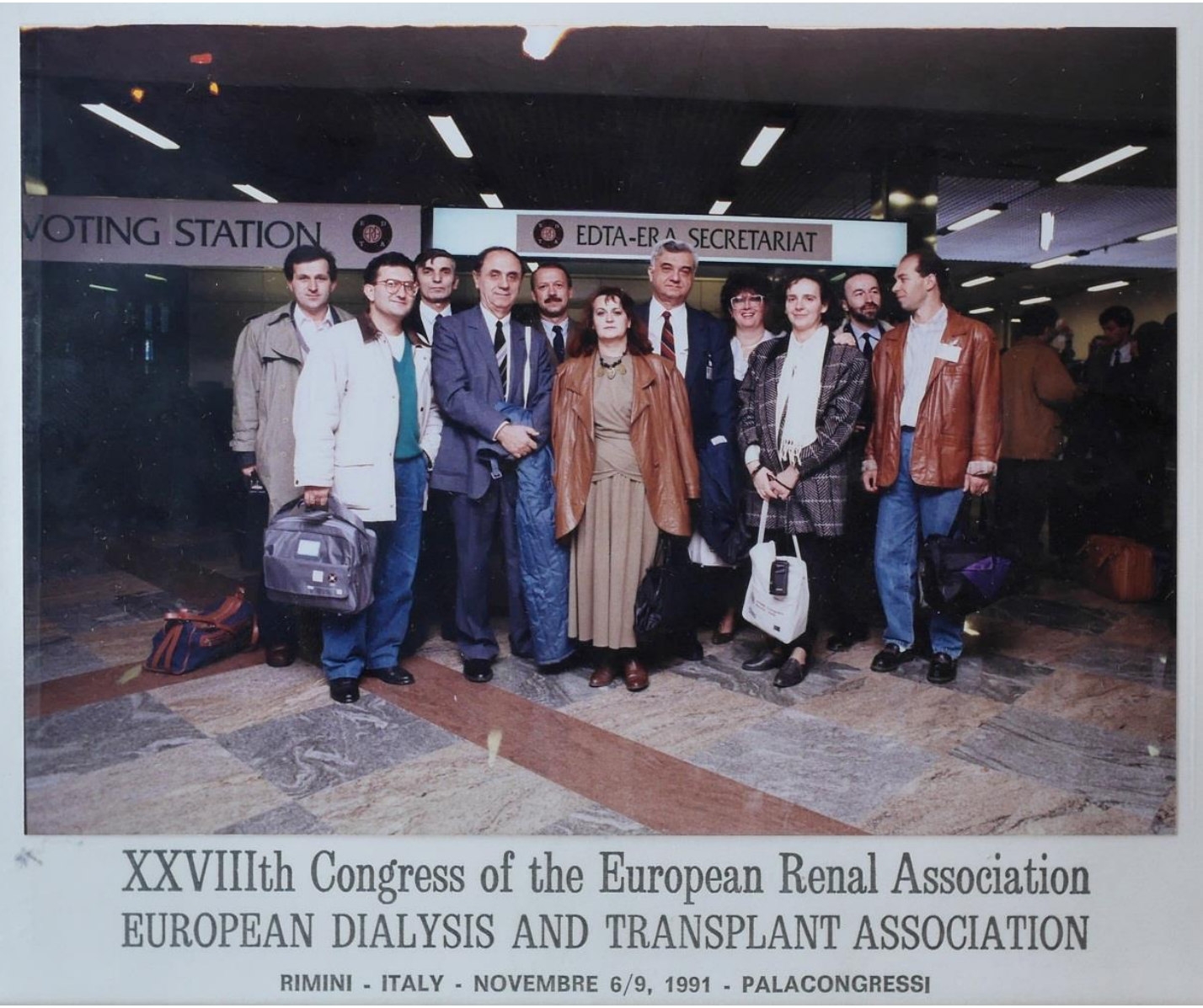

Fig. 10-Macedonian participants at the Congress in Rimini 
The war in former Yugoslavia negatively affected the development of nephrology and also the connections among the nephrologists from the Balkans. However, there was willingness for further mutual collaboration between the nephrologists from the Balkans.

So, in Skopje, in 1991, the nephrologists from Macedonia (M. Polenakovic), Bulgaria (D. Nenov), Serbia (A. Radmilovic) and Turkey (K. Onen) launched an idea to establish a new association between the Balkan countries - Balkan Society of Nephrology.

The Macedonian Society of Nephrology, Dialysis, Transplantation and Artificial Organs (MSNDTAO) was established in 1992 and M. Polenakovic was President of the Society in the period 1992-2011, and later on a lifetime honorary President. The Society was established with intention to gather specialists in different medical areas and non-medical areas (biology, engineering, chemistry, mathematics etc.) and to point out the work on the artificial organs. In addition, the idea was to make a connection with the European Society for Artificial Organs, as well as extending the existing relations with the ERA-EDTA.

In the meantime, M. Polenakovic as renowned nephrologist from the Balkans was invited to the group of world nephrologists that visited Pope Jean Paul II in Vatican in 1990. The aim of the visit was to ask the Pope to give a blessing to the organ transplantation. After the visit, an increase of transplantation was noted among the Catholic population, especially in South America. 


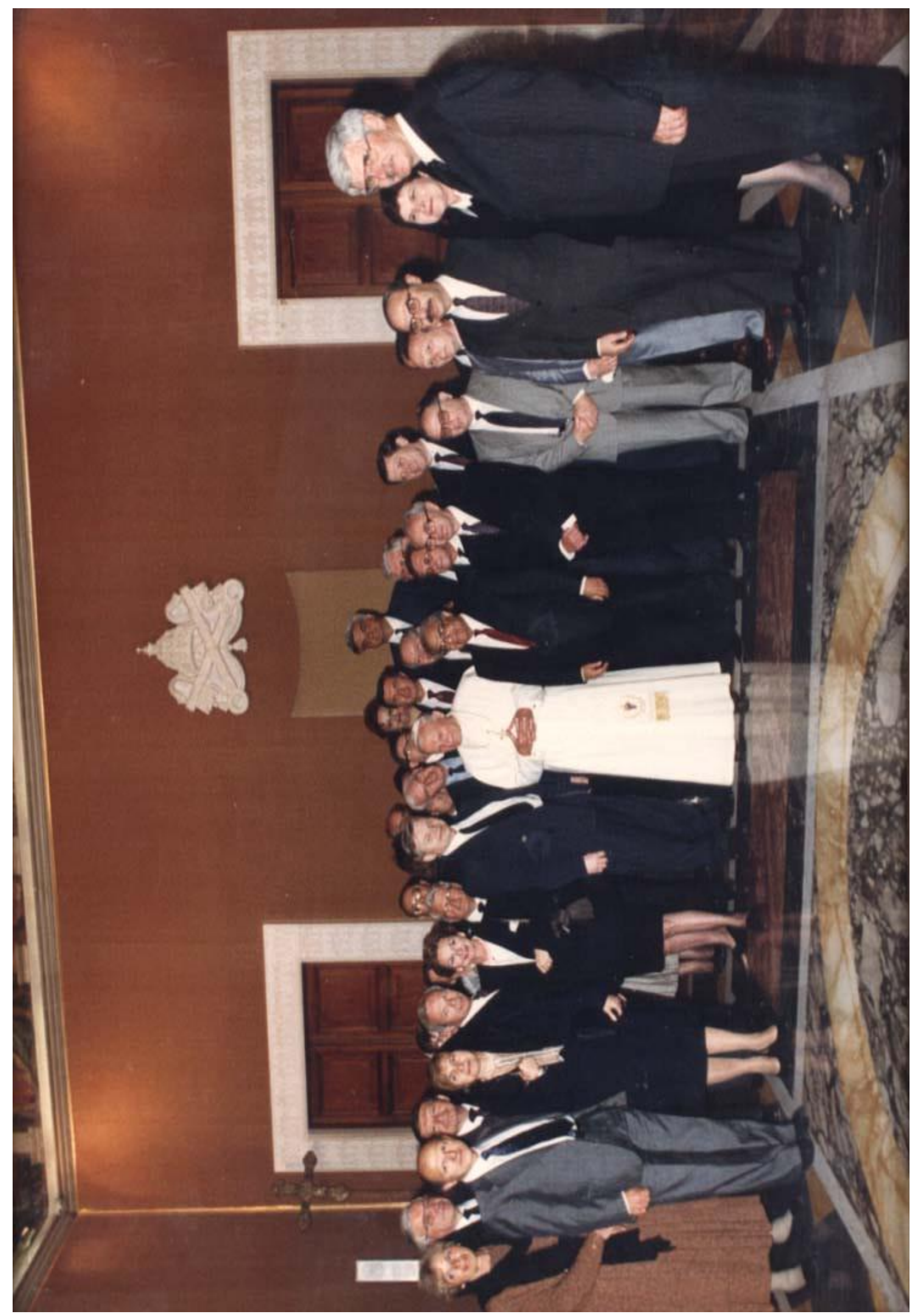

Fig. 11 - Visit to the Holy Father, Vatican (1990) 


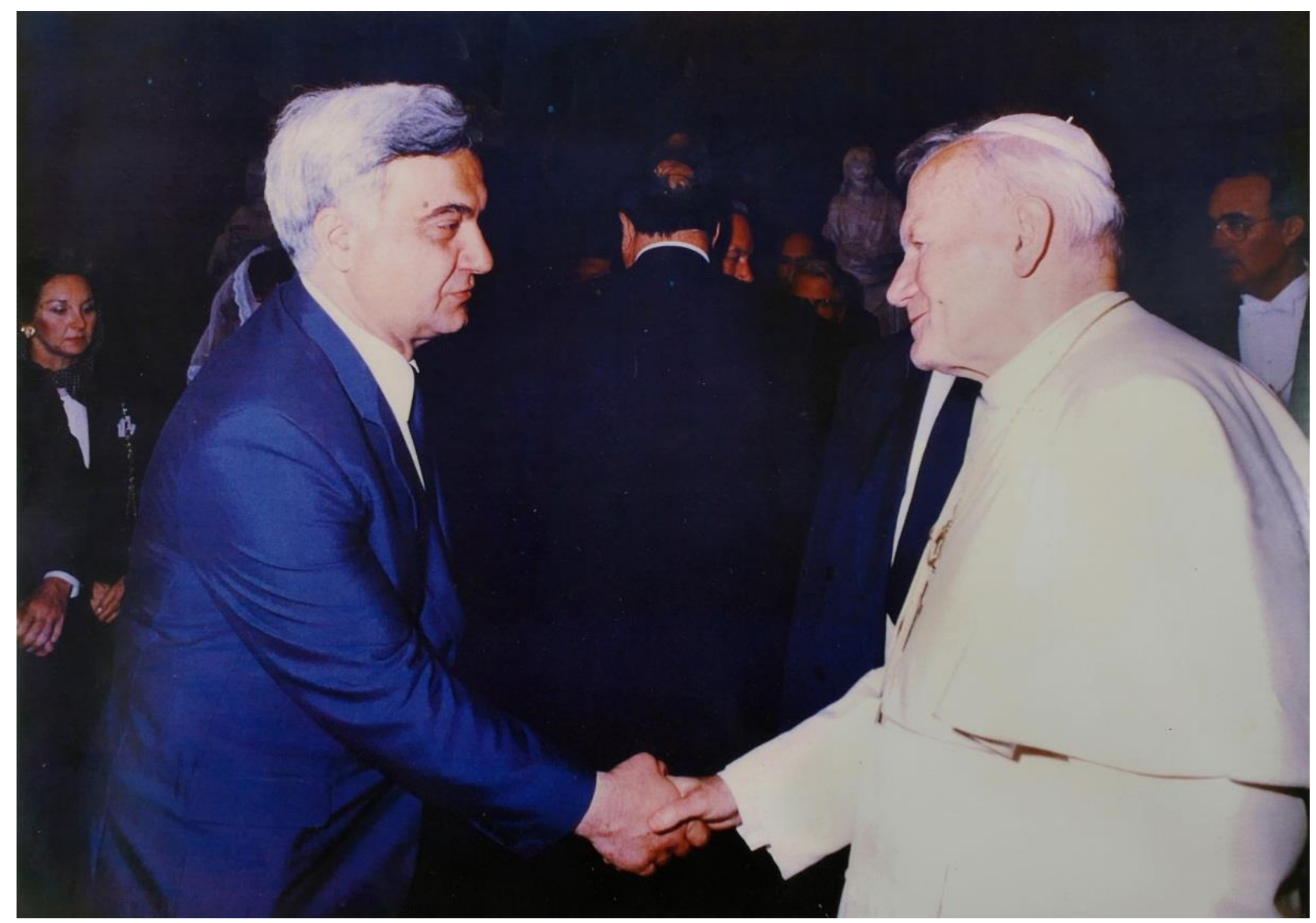

Fig. 12 - M. Polenakovic and the Holy Father, Vatican (1990)

In 1993, the First Congress of the MSNDTAO was held in Ohrid under the Presidency of M. Polenakovic. During the Congress an idea to create BANTAO Association (Balkan Cities Association of Nephrology, Dialysis, Transplantation and Artificial Organs) was also launched. The establishment of BANTAO was a great success of the Macedonian and Balkan nephrologists, as well as personally of M. Polenakovic.

The war in Yugoslavia created hatred among people, between the newly established countries, and there were problems with the re- cognition of the names of the new countries, and so, the nephrologists decided to apply the ancient principle of using the names of the cities, instead of the countries, as the founders of the Association.

Beside nephrologists from the Balkan cities, our international and well recognized colleagues and friends Prof. H. Klinkmann, Prof. J. Vienken, Prof. E. J. Dorhout Mees, Prof. D. Falkenhagen and Prof. P. Ivanovich helped us in creation of a platform for the Association. 


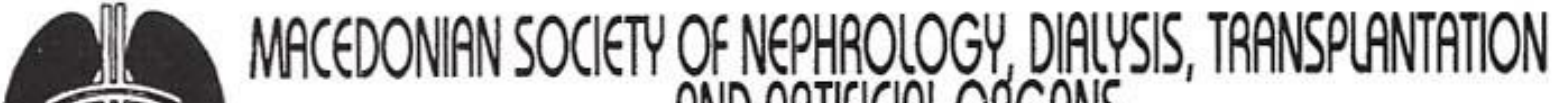 AND ARTIFCCALL ORGANS}

President,

Society of Nephrology

$9 \cdot 10 \cdot 1993$

Dear Colleague:

In 1991 during a special meeting in Skopje, Macedonia, several representatives of the various societies of Nephrology and Artifical Organs started an initiative to found a Balkan Society of Nephrology and Artifical Organs. This initiative was expressed in a letter to your society dated May 17, 1991. This, initiative has grown with time and at the recent First Congress of the Macedonian Society of Nephrology, Dialysis, Transplantation and Artificial Organs, a task force was formed by representatives of different societies from the Balkan area to make this project a reality. It was clear for the participants that the founding of such a society would have clear impact on several aspects of the practice and research in Nephrology and artificial organs in the Balkan by first increasing the international visibility and potential collaborative work as well as recognition by international organizations. Secondly, such a society would facilitate exchange of experience and knowledge between the experts in our area. In addition it would be a very positive symbolic act showing that collaborative work for the betterment of life is possible and desirable in our area and that coming together will bave better fruits on the human and cultural levels. It will also send a very clear signal to the outside world that the Balkans can be a place of collaboration and mutual understanding. Several international bodies such as the International Society of Artificial Organs and the International Faculty of Artificial Organs have signalled their interest and support in the formation of such a society.

The task force would like to invite your society and you personally to participate in the planning meeting and possibly the founding meeting to be held in Sofia, Bulgaria on the 15 th of January 1994. For further information please contact the chairman of the Task force Prof Dr Momir Polenakovic, President of the Macedonian Society of Nephrology, Dialysis, Transplantation, and Artificial Organs.

We look forward to your active participation in this important task,

Sincercly,

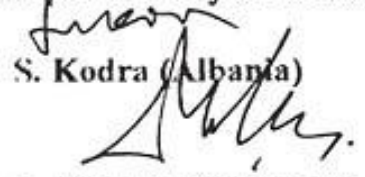

Z. Kirjakov (Bulgaria)

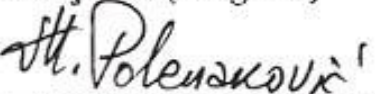

II. Polenakoyic (Ylacedonia)

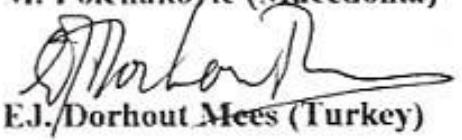

A.Radmilovic (Yugestavia)

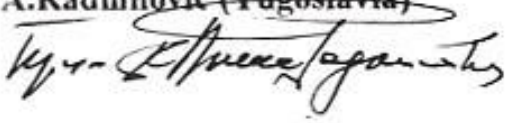

D. Nenor (Bulgaria)

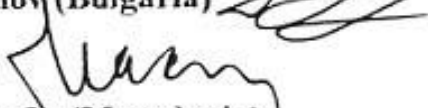

Gj. Masth (Macedonia)<smiles>CC(C)CC(C)C(C)(C)C(C)(C)C(C)(C)C</smiles>

$$
\text { thon caus }
$$

Lj. Djukanovic (Ýugoslavia)

$$
\text { Las.cprame }
$$

S. Strahinjic (Yugoslavia)

Fig. 13 - Letter of intention for establishing the BANTAO 


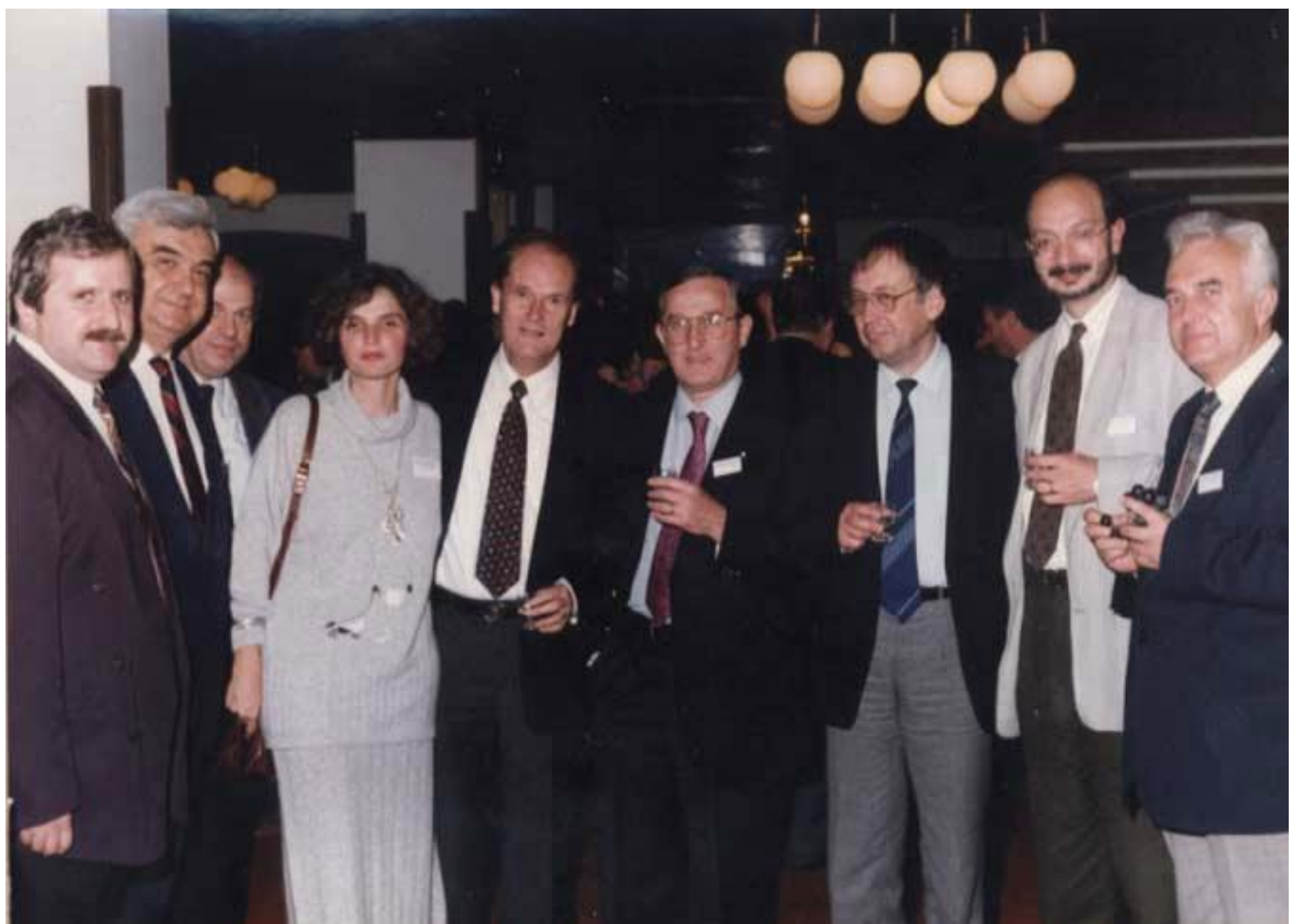

Fig. 14 - Some of the Participants of the I Congress of the MSDNTAO and Founders of BANTAO

So far eleven BANTAO congresses were held, and the $12^{\text {th }}$ will be organized in Opatija, Croatia in 2015.

The establishment of the BANTAO has been accepted very positively among the nephrology community in Europe. Our well known colleague Prof. Fernando Valderrabano, from Spain, has published a congress report from the First BANTAO Congress: "Nephrologists of the Balkan countries meet across political frontiers and war fronts - an example to politicians!" In his report he wrote: "This is an extraordinary initiative of nephrologists working in cities throughout the Balkan countries who have been able to create a scientific association and to organize its first congress, despite the boundaries of war, the rupture of international relations and other serious political problems which emerged in the Balkan coun- tries after the disappearance of the former Republic of Yugoslavia"... "The main goal of BANTAO is to promote scientific and technical cooperation in the field of renal diseases and artificial organs between the Balkan cities"... "BANTAO wants to work closely with other international societies, especially with EDTA-ERA"... "BANTAO represents an extraordinary initiative and should receive both scientific and economic support from the EDTAERA"... "The exceptional effort of collaboration shown by our Balkan colleagues, who have been able to carry out scientific activities in extremely adverse human conditions, is an example to the European nephrological community, which should not hesitate to offer all possible help to this new association". [NDT (1996) 11: 740] 


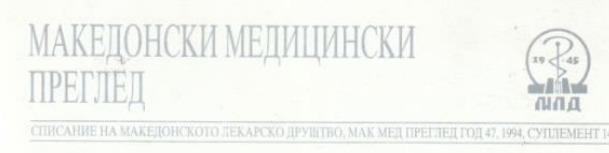

МАКЕДОНСКО ЗДРУЖЕНИЕ 3А НЕФРОПОГИА,

ДИАПИЗА, ТРคНССПЯНТТАЦИА И ВЕШТАЧКИ ОРГАНИ

\section{НЕФРОЛОГИЈА}

93

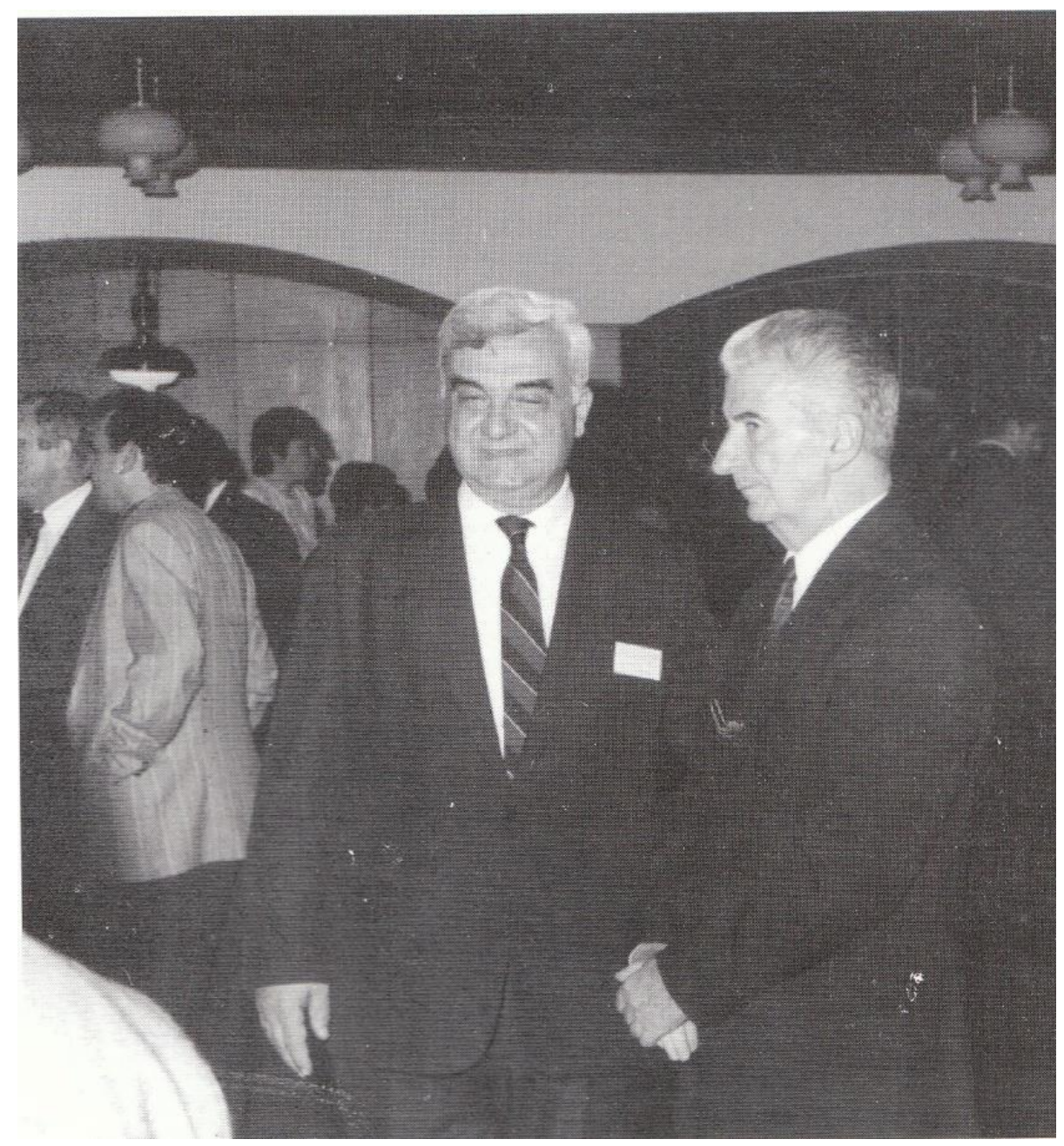

Fig. 15 - Proceedings of the I Congress of the MSNDTAO - 1993 and M. Polenakovic with K. Gligorov, President of the Republic of Macedonia in that period 
МАКЕДОНСКО ЗДРУЖЕНИЕ ЗА НЕФРОЛОГИЈА, ДИЈАЛИЗА, ТРАНСПЛЛАНТАЦИЈА И ВЕШТАЧКИ ОРГАНИ MACEDONIAN SOCIETY OF NEPHROLOGY, DIALYSIS, TRANSPLANTATION AND ARTIFICIAL ORGANS

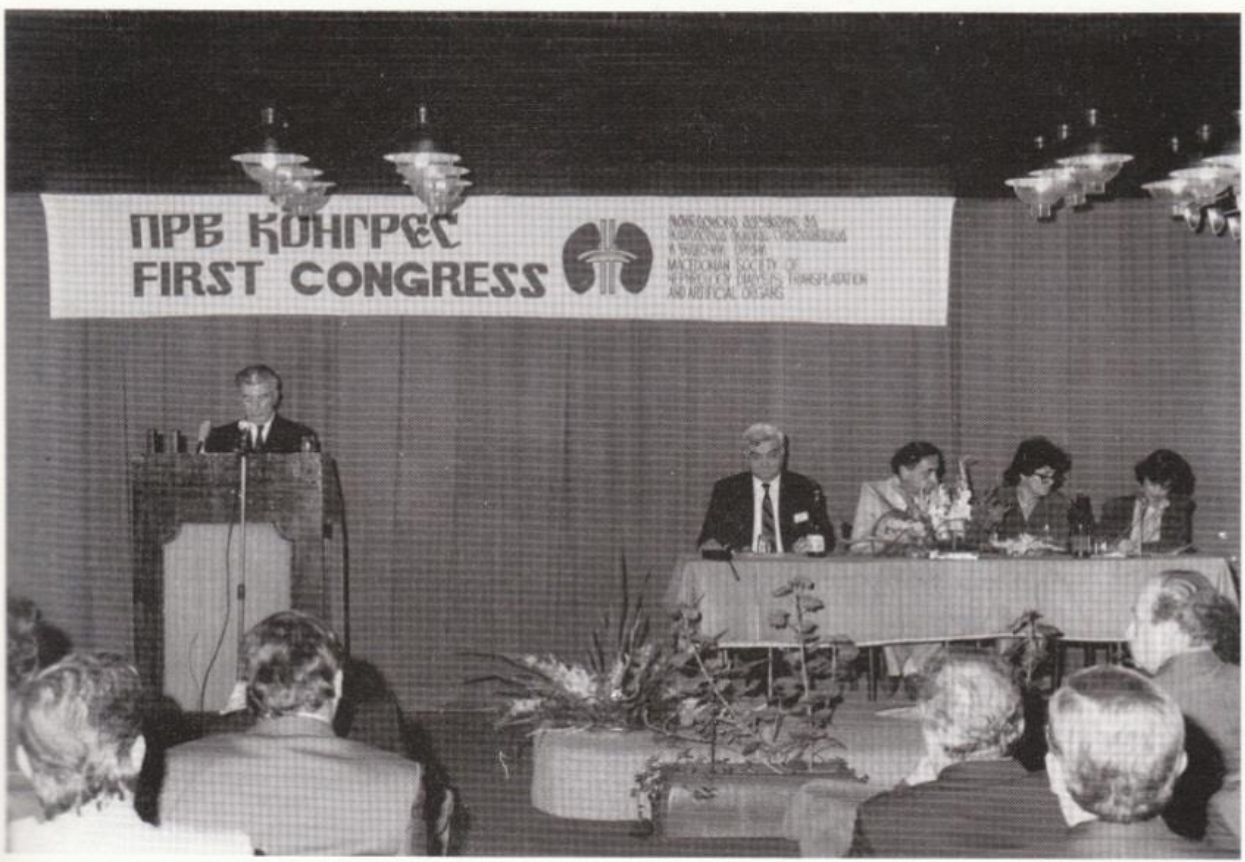

Прв конгрес на

Македонското здружение за

нефрологија, дијализа,

трансплантација и

вештачки органи

Покровител:

\section{Г-дин Киро Глигоров}

Претседател на

Република Македонија
First Congress of the

Macedonian Society of

Nephrology, Dialysis,

Transplantation and

Artificial Organs

Patron:

\section{Mr. Kiro Gligorov}

President of the

Republic of Macedonia

Fig. 16-I Congress of the MSNDTAO - 1993

Selected papers of the Congress were published in the Proceedings of the Congress. Among them, for the first time in the Republic of Macedonia was published the Doctrine in Nephrological Health Care in the Republic of Macedonia. It was a significant contribution for better diagnosis and treatment of renal disease in the Republic of Macedonia.

The second congress of BANTAO was held in Ohrid in 1997 under the Presidency of M. Polenakovic with the participation of renowned international nephrologists from former Yugoslaviacountries. 


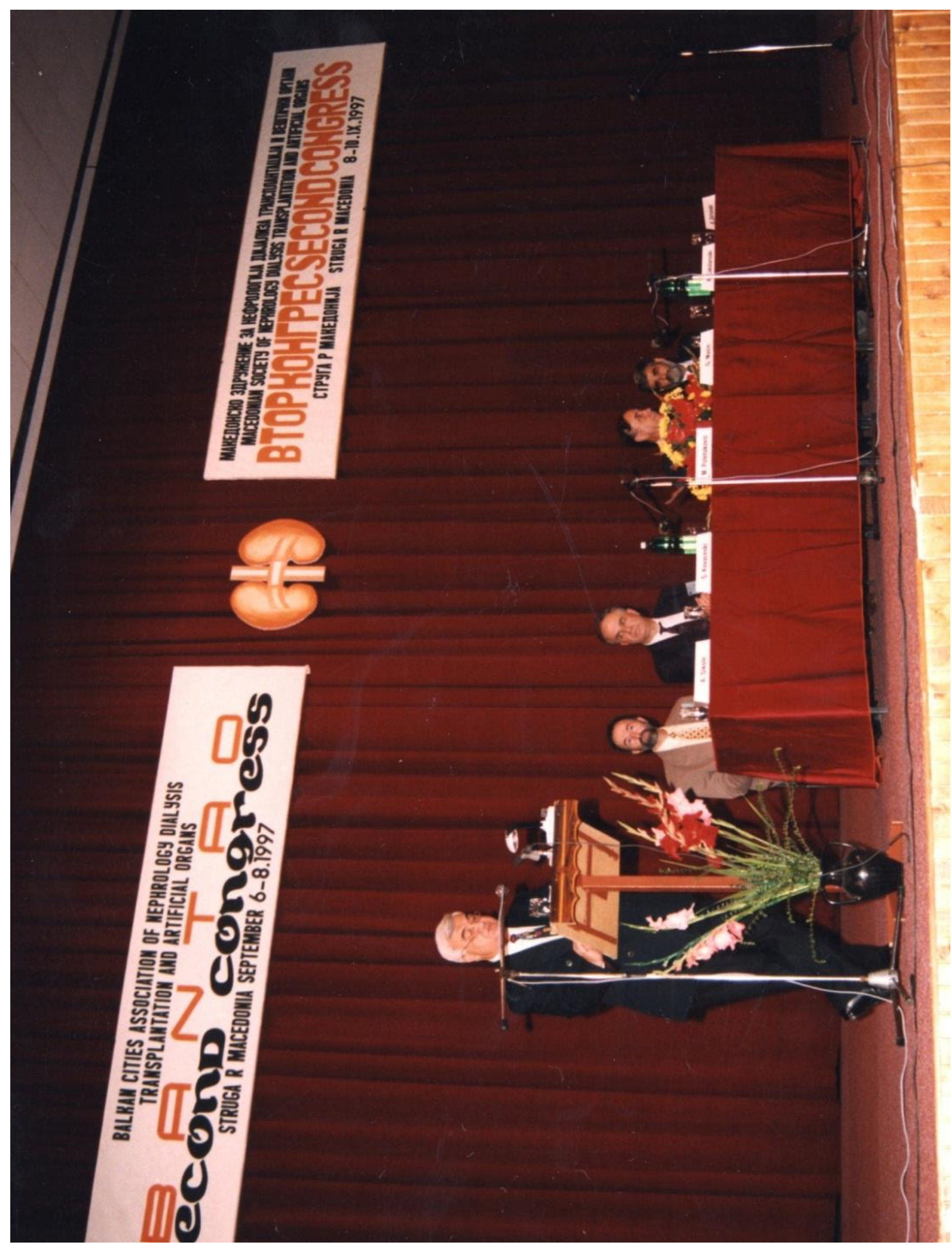

Fig. 17 - Participants at the Second congress of BANTAO, from left to right: M. Polenakovic, A. Sikole, S. Kovacevski, G. Masin and K. Cakalarovski 


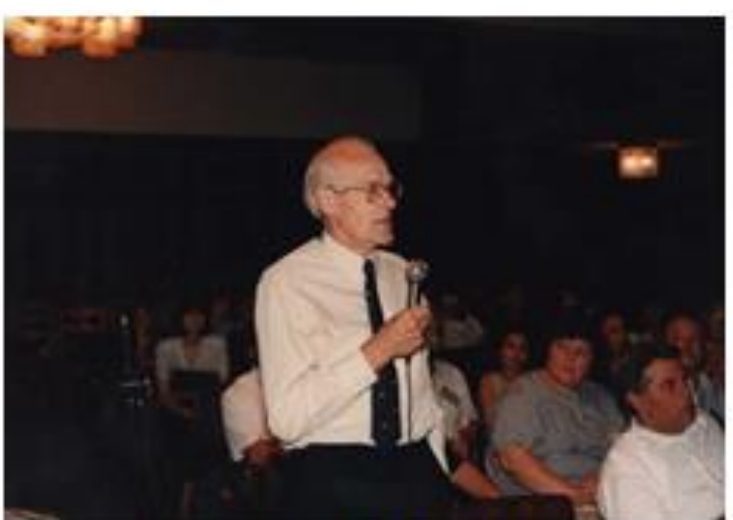

E. J. Dorhout Mess (Izmir)

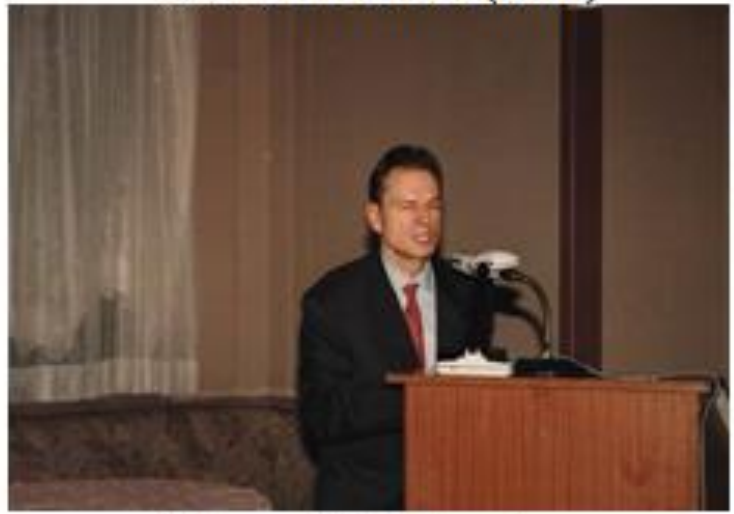

P. Iranovich (Chicago)

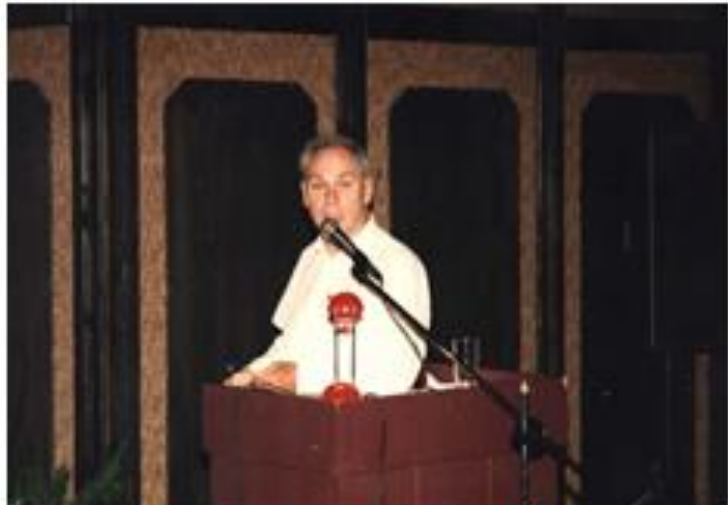

J. S. Cameron (London)

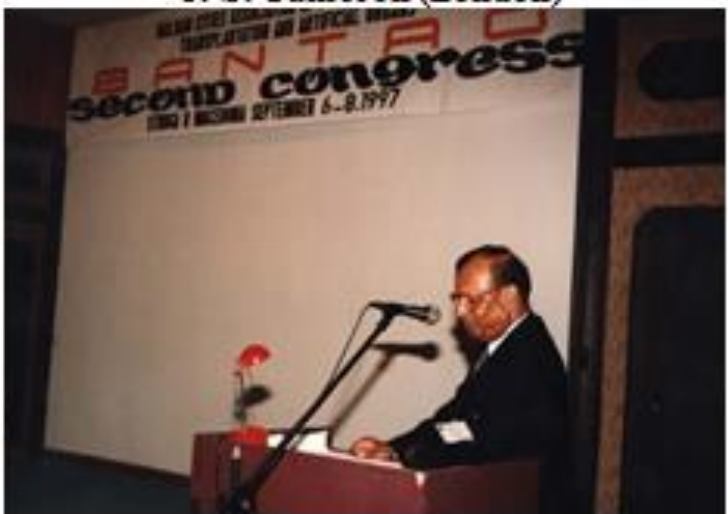

A. Mandal (Davton)

Fig. 18 - Participants at the Second congress of BANTAO

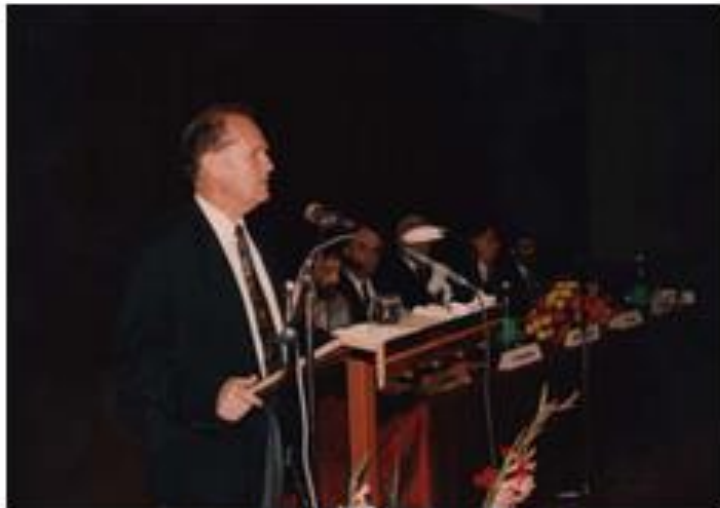

H. Klinkmann (Rostock)

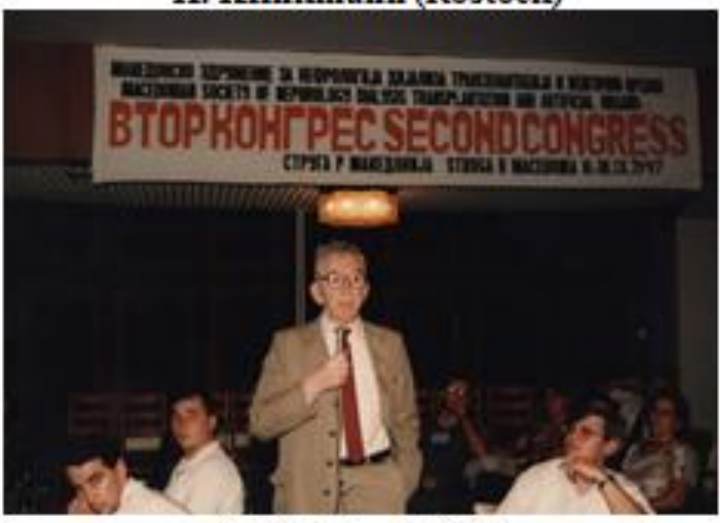

S. Strahinjic (Nis)

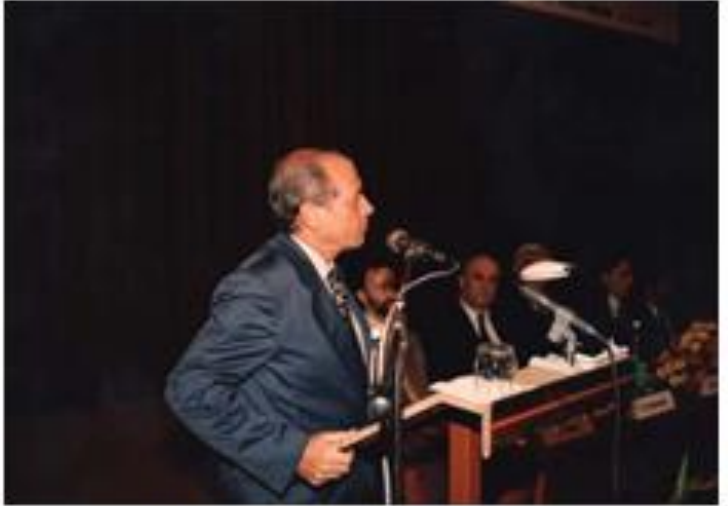

P. Schena (Bari)

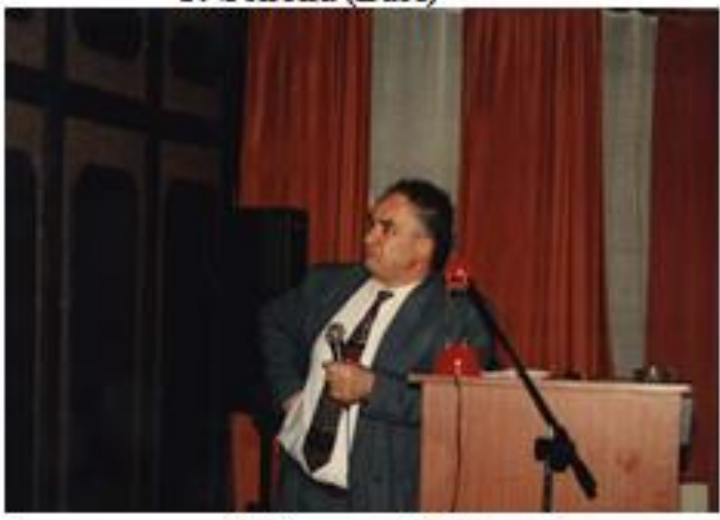

S. Kovaceski (Struga)

Fig. 19 - Participants at the Second congress of BANTAO 


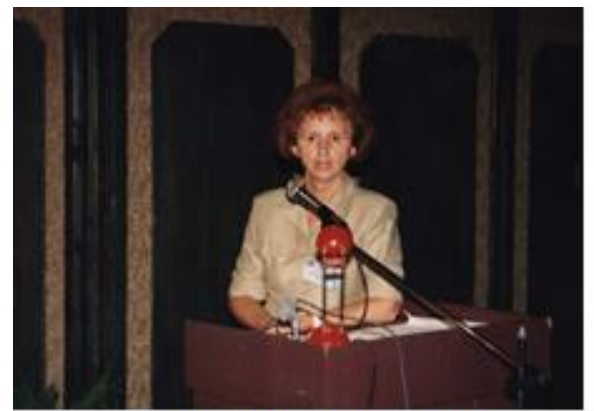

Lj. Djukanovic (Belgrade)

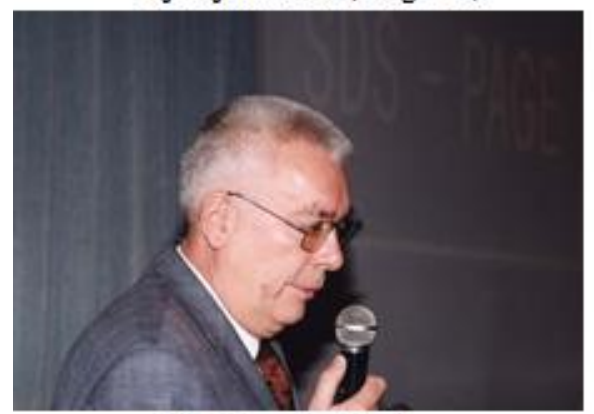

H. Maan (Aachen)

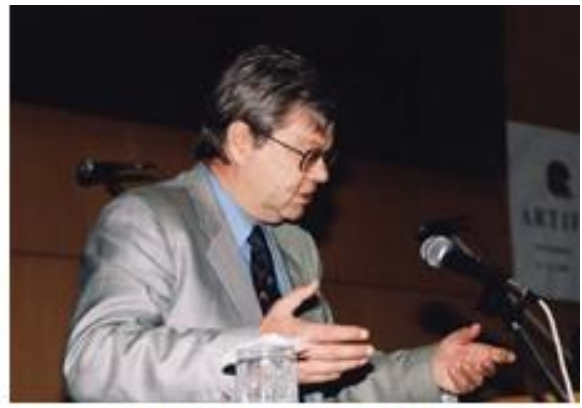

D. Falkenhagen (Krems)

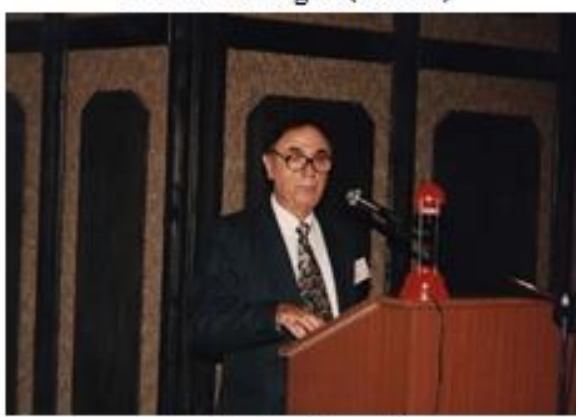

G. Masin (Skopie)

Fig. 20 - Participants at the Second congress of BANTAO

The Seventh BANTAO congress was held in 2005 in Ohrid under the Presidency of M. Polenakovic with the participation of renowned international nephrologists from former Yugoslavia countries and other nephrologists from the Balkans. President of the congress was M. Polenakovic and Secretary General was G. Spasovski. At this 7th BANTAO Congress Goce Spasovski has organized for the first time a CME Course organized by ERAEDTA and ISN/COMGAN entitled Frontiers in Nephrology, with seven distinguished speakers from ERA-EDTA. In addition, the European Uuremic Toxinscity group (EUTox), under the umbrella of ESAO has contributed to the congress with a round table entitled: An update on uremic toxicity.

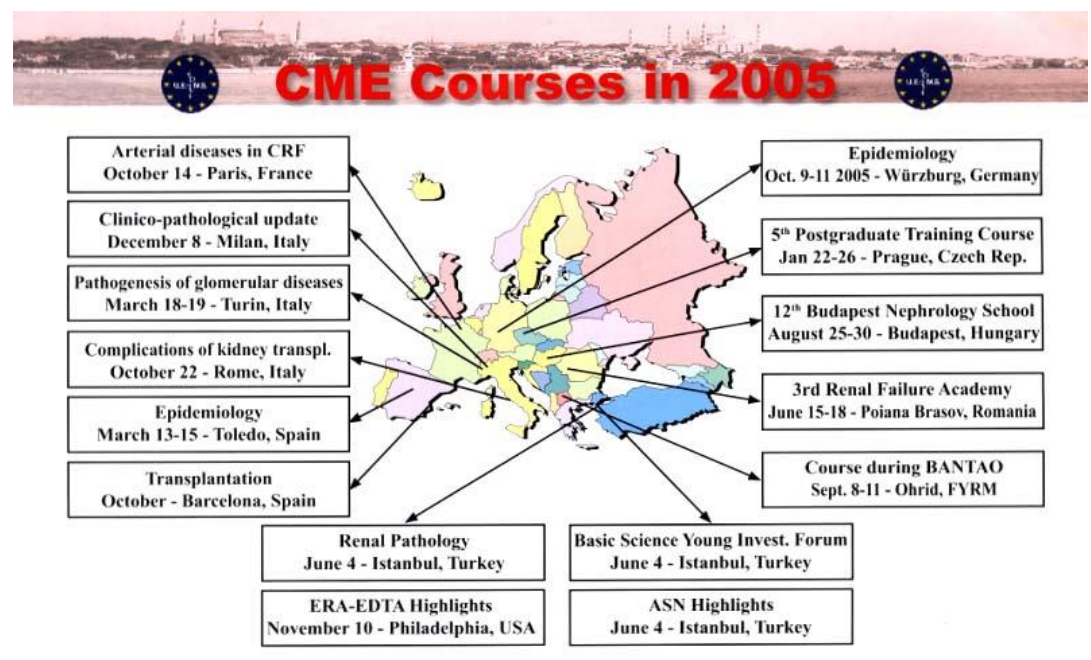

Fig. 20-CME courses in 2006

The congress was focused on several topics, as for example: How to improve the Balkan renal registry; Prevention in nephrology;
Prevention of progression of renal disease; Understanding renal fibrosis; and Kidney transplantation in the Balkan Peninsula. 


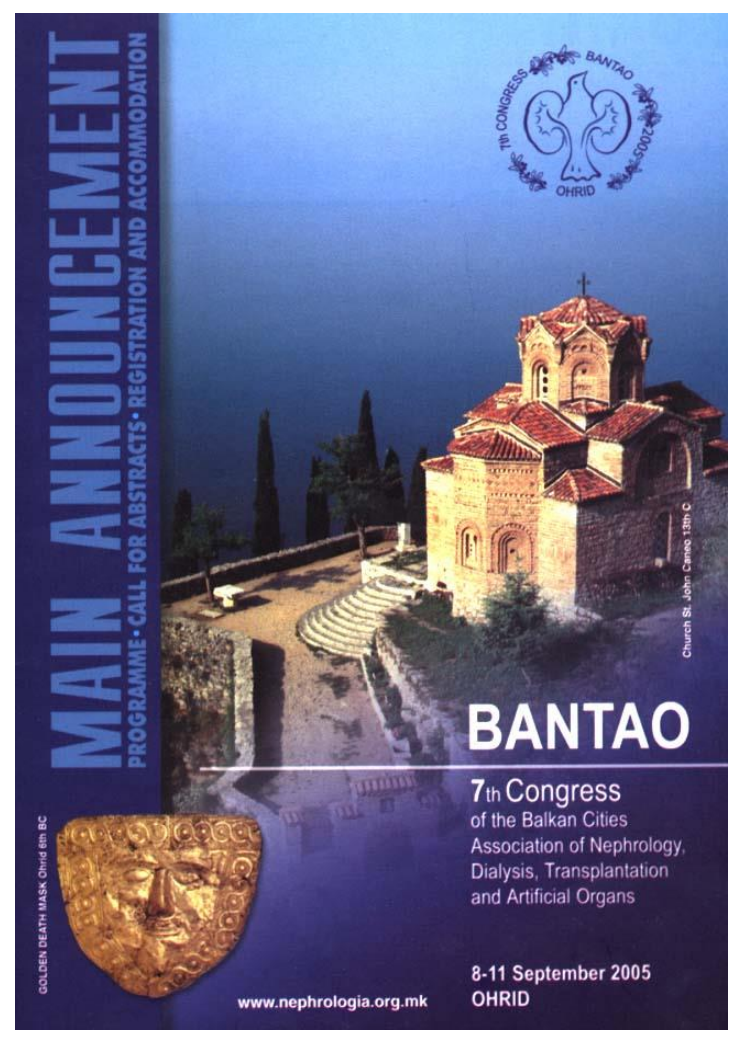

BANTAO Journal

Proceedings of the 7th BANTAO Congress September 8-11, 2005, Ohrid

\section{Editors of this issue}

Goce Spasovski

Momir Polenakovic $\quad$ Skopje

\section{Editorial Board}

Ali Basci

Junus Erdem

Momir Polenakovic

Katica Zafirovska

Charalambos Stathakis

John Boletis

Veselin Nenov

Daniela Monova

Ljubica Djukanovic

Vladislav Stefanovic

Alketa Korosh

Adrian Covic

Rado Kveder

Petar Kes

Halima Resic

Izmir

Ankar:

Skopje

Skopje

Athens

Athens

Varna

Sofia

Belgrade

Nis

Tirana

Ljubljana

Ljubljan
Zagreb

Sarajevo

Fig. 21 - VII BANTAO Congress, Ohrid, 2005

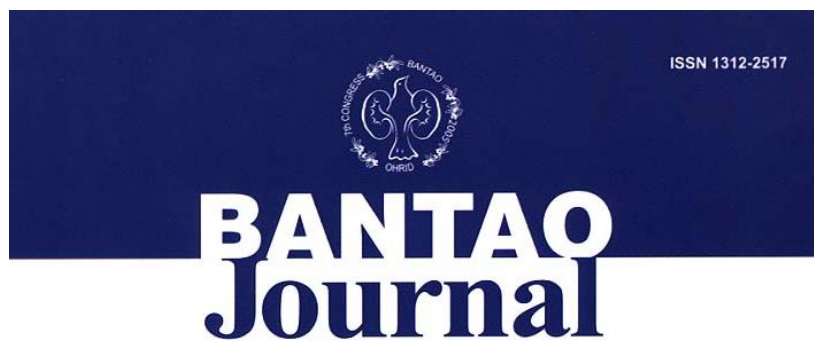

Official Publication of the Balkan Cities Association of Nephrology,

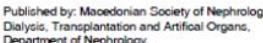

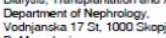

\section{ABSTRACT BOOK}

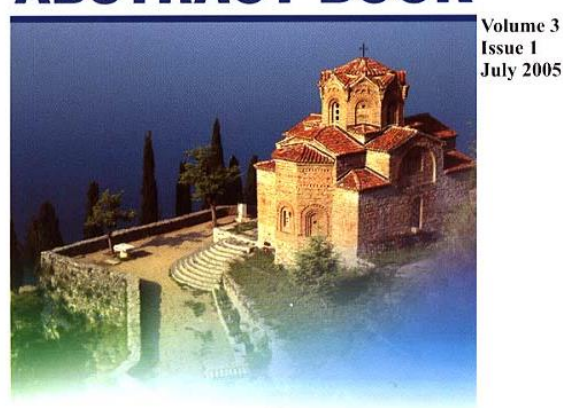

7.th BANTAO Congress of the Balkan Cities

Association of Nephrology, Dialysis,

Transplantation and Artificial Organs,

September 8-11, 2005, Ohrid 


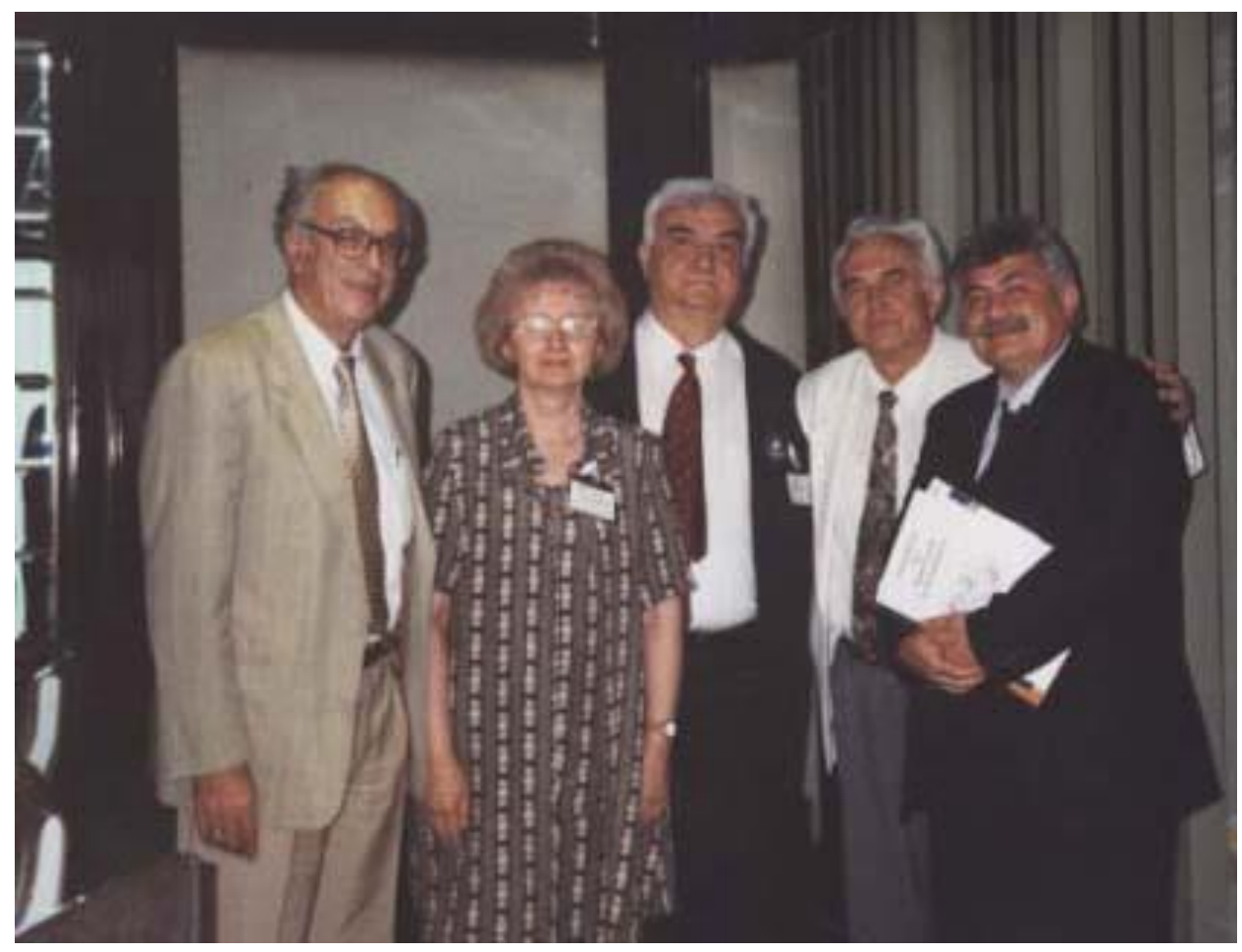

Fig. 23 - Participants at the VII BANTAO Congress: (from left to right) H. Stathakis (Athens), Lj. Dukanovic (Belgrade), M. Polenakovic (Skopje), D. Nenov (Varna) and A. Basci (Izmir)

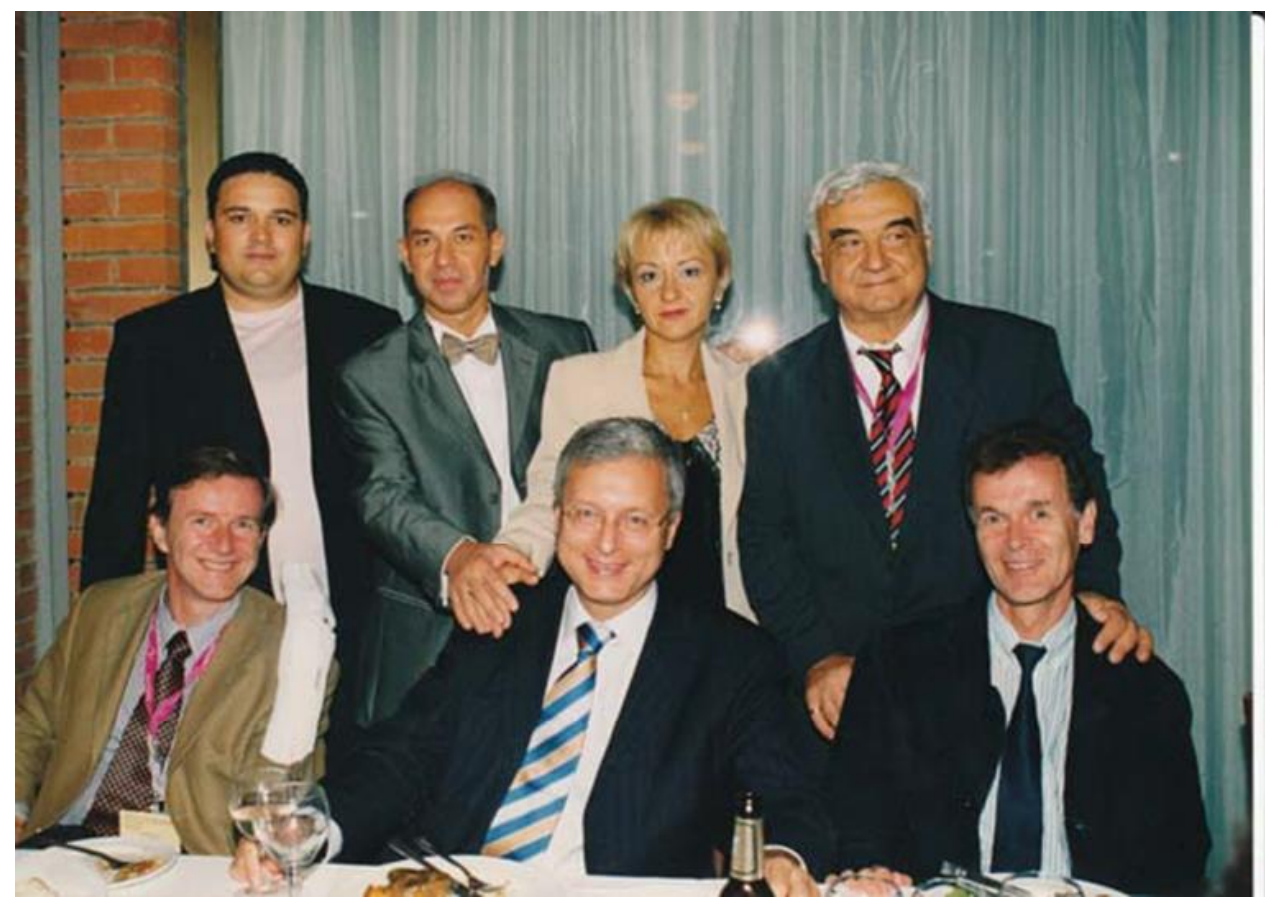

Fig. 24 - Participants at the VII BANTAO Congress: (standing from left to right) O. Malenko (Ohrid), G. Spasovski (Skopje), J. Masin Spasovska (Skopje), M. Polenakovic (Skopje), (sitting from left to right) J. Floege (Aachen), A. Wiecek (Katowice) and J. Mann (Munich)

In the meantime Prof. Polenakovic has also participated in the work of the European Society of Artificial Organs (ESAO) where he was Governor in the period 1996-2004. He was also active in the work of the European
Renal Association (ERA-EDTA). In the period 1993-2003 he was a Key-man of the Commission for Acute renal failure of the International Society of Nephrology. 


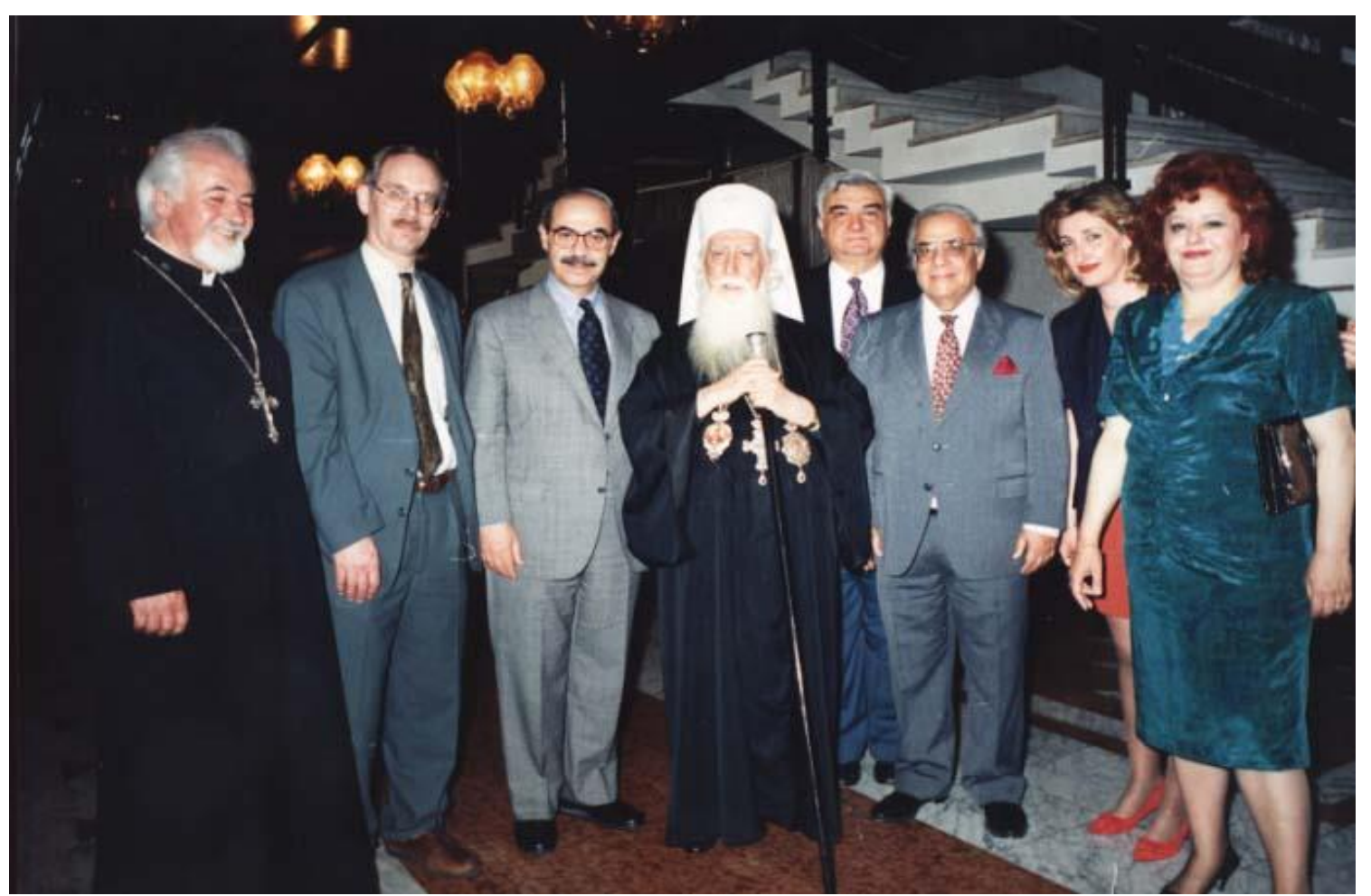

Fig. 25 - Participants at the International Conference Renal Aspects of Disaster Relief, May 24-26, 1996 - Second from left K. Solez (Canada), G. Eknoyan (USA), Archbishop Mihail (Republic of Macedonia), M. Polenakovic (Republic of Macedonia), H. Massry (USA), O. Stojceva (Republic of Macedonia) and B. Polenakovic (Republic of Macedonia)

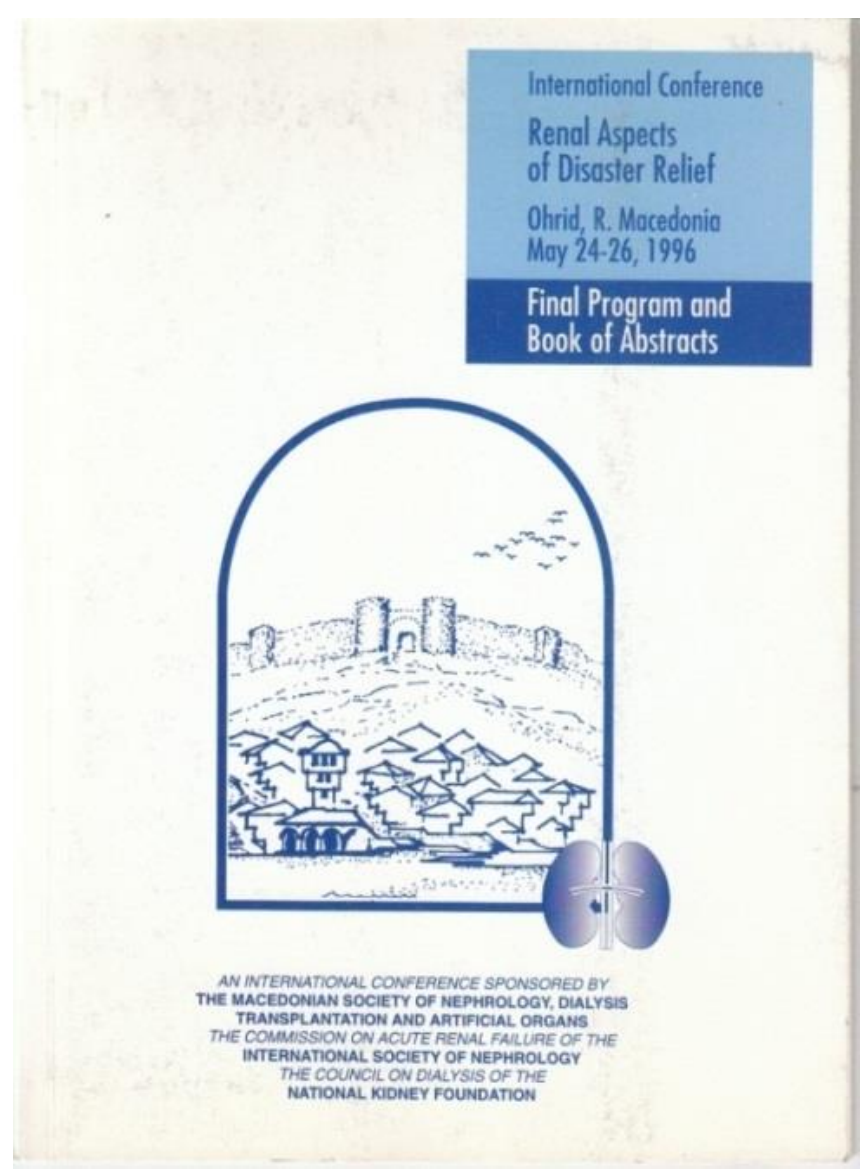

Fig. 26 - Proceedings of the International Conference Renal Aspects of Disaster Relief, May 24-26, 1996 


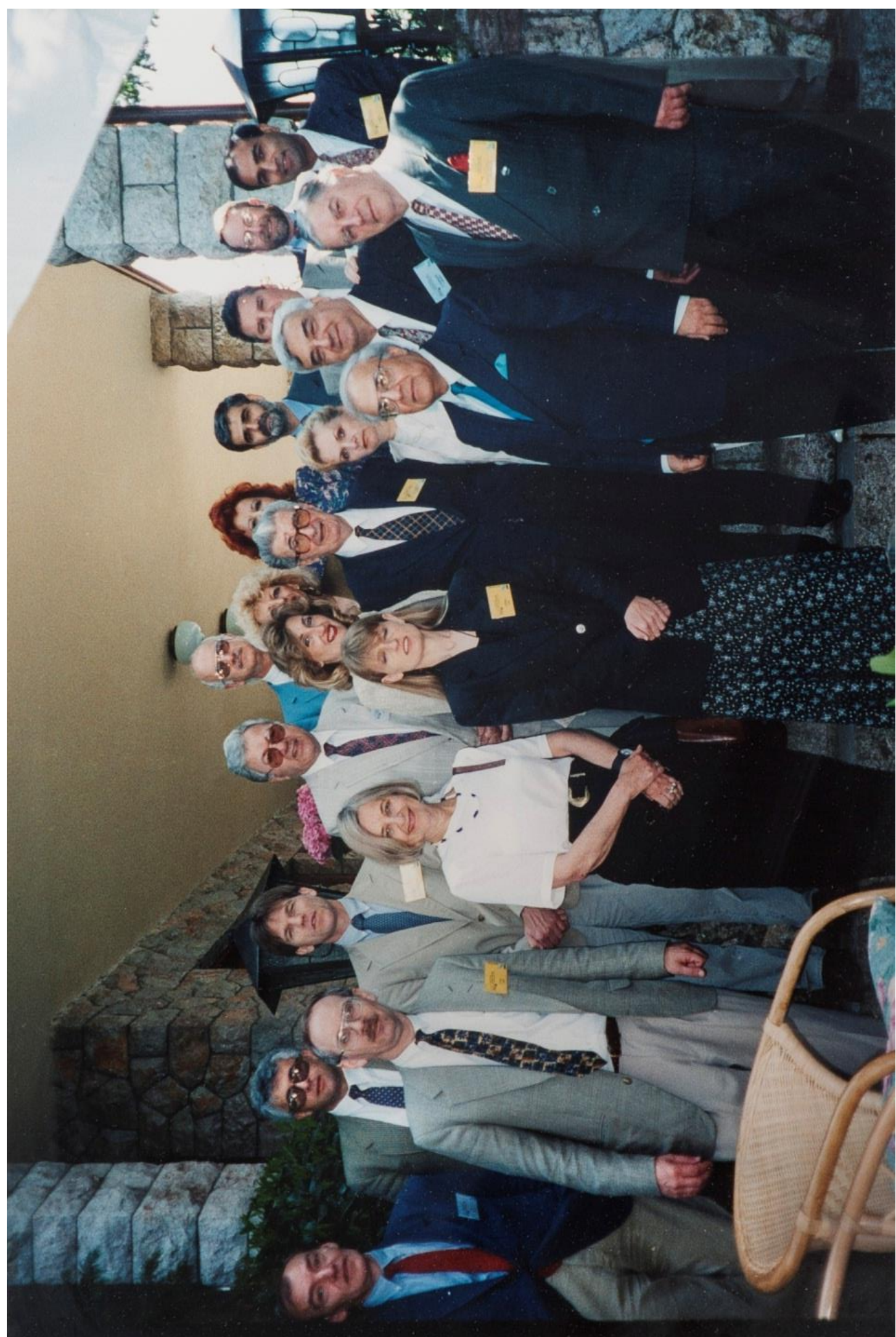

Fig. 27 - Participants at the Conference with K. Gligorov, President of the Republic of Macedonia

M. Polenakovic participated in the Transplantation and Artificial Organs and organization of all (4) congresses of the was the editor of the Proceedings of the Macedonian Society of Nephrology, Dialysis, congresses. 

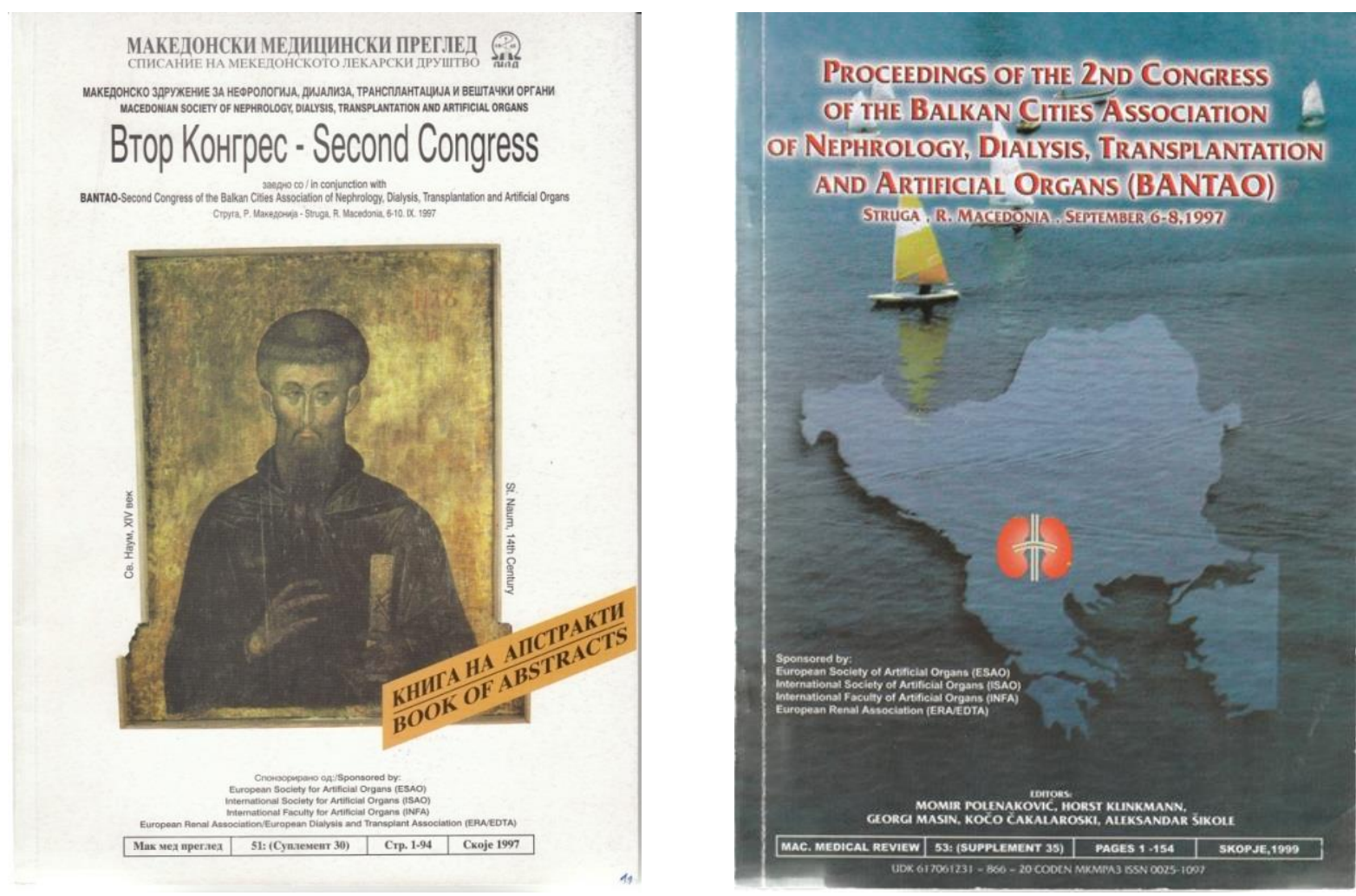

Fig. 28 - Proceedings of the Second MSNDTAO Congress, Struga 1997
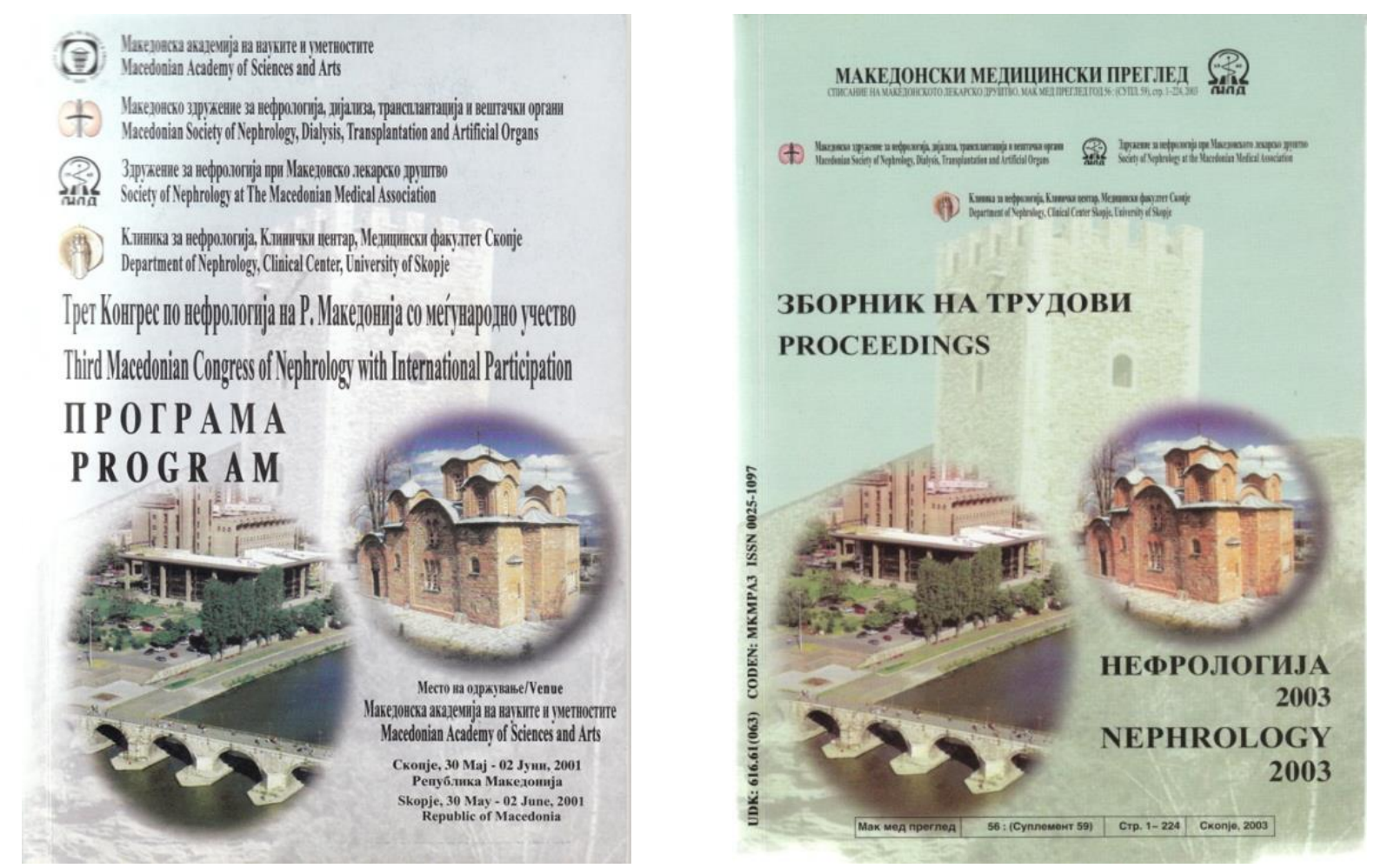

Fig. 29 - Proceedings of the Third MSNDTAO Congress, Skopje 2001

In November 2000, the Symposium Artificial Organs 2000 was held in the Macedonian Academy of Sciences and Arts. Within the me- eting papers of Macedonian and foreign authors were presented and afterwards published in the Journal of Artificial Organs. 


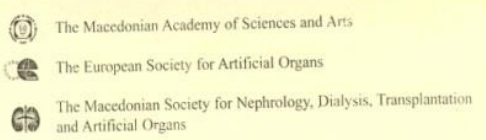

ABSTRACT BOOK

\section{ARTIFICIAL ORGANS 2000}

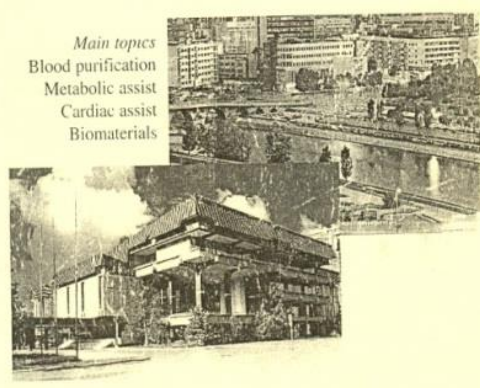

Notember 25-26, 2000

Macedonian A cademy of Sciences and Arts, Skopje, Republic of Macedonta

\section{Artificial Organs 2000}

Satellite Symposium

European Society for Artificial Organs (ESAO)

Skopje, Republic of Macedonia

November $25-26,2000$

Special issue of:

The International Journal of Artificial Organs

Fig. 30 - Abstract book and Special Issue of the Journal of Artificial Organs

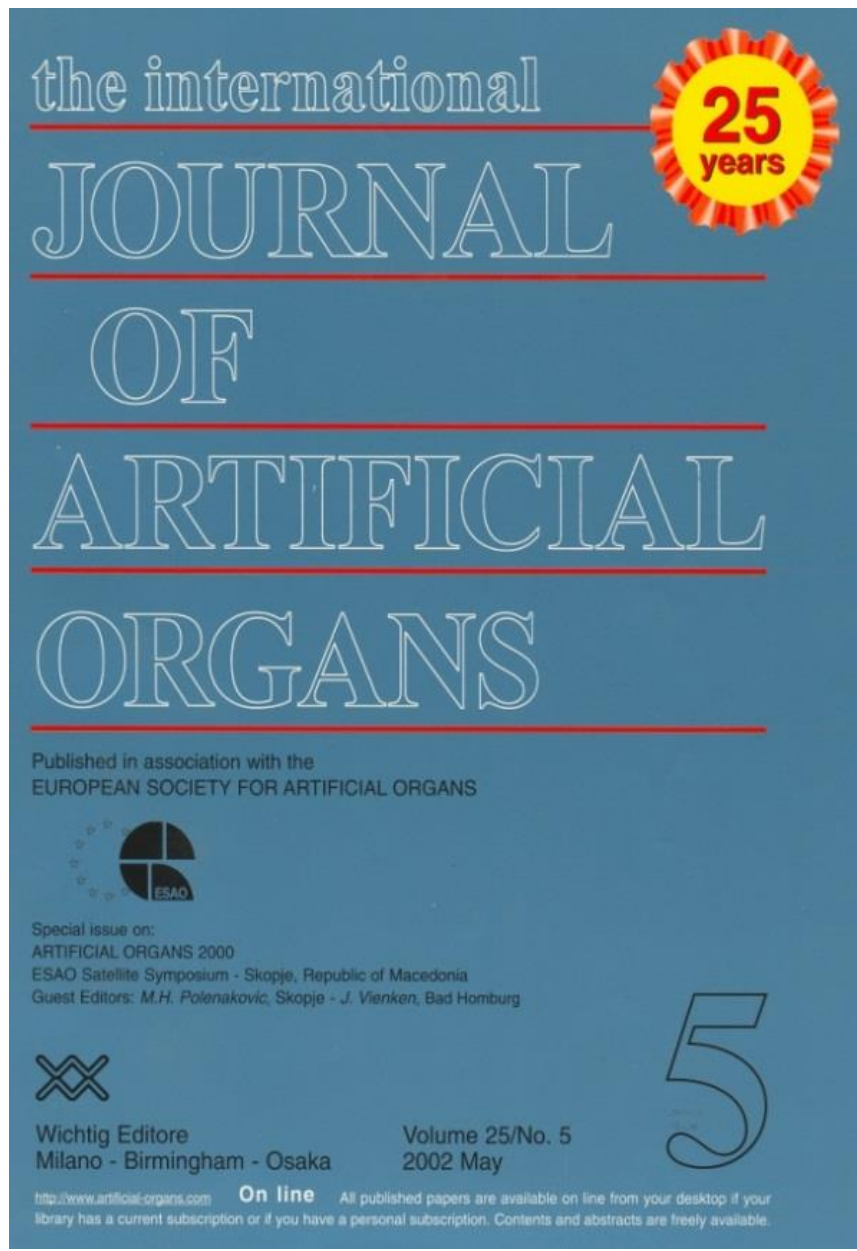

Fig. 31 - Special Issue of the Journal of Artificial Organs

Momir Polenakovic Skopje, Republic of Macedonia Joerg Vienken Bad Homburg, Germany 


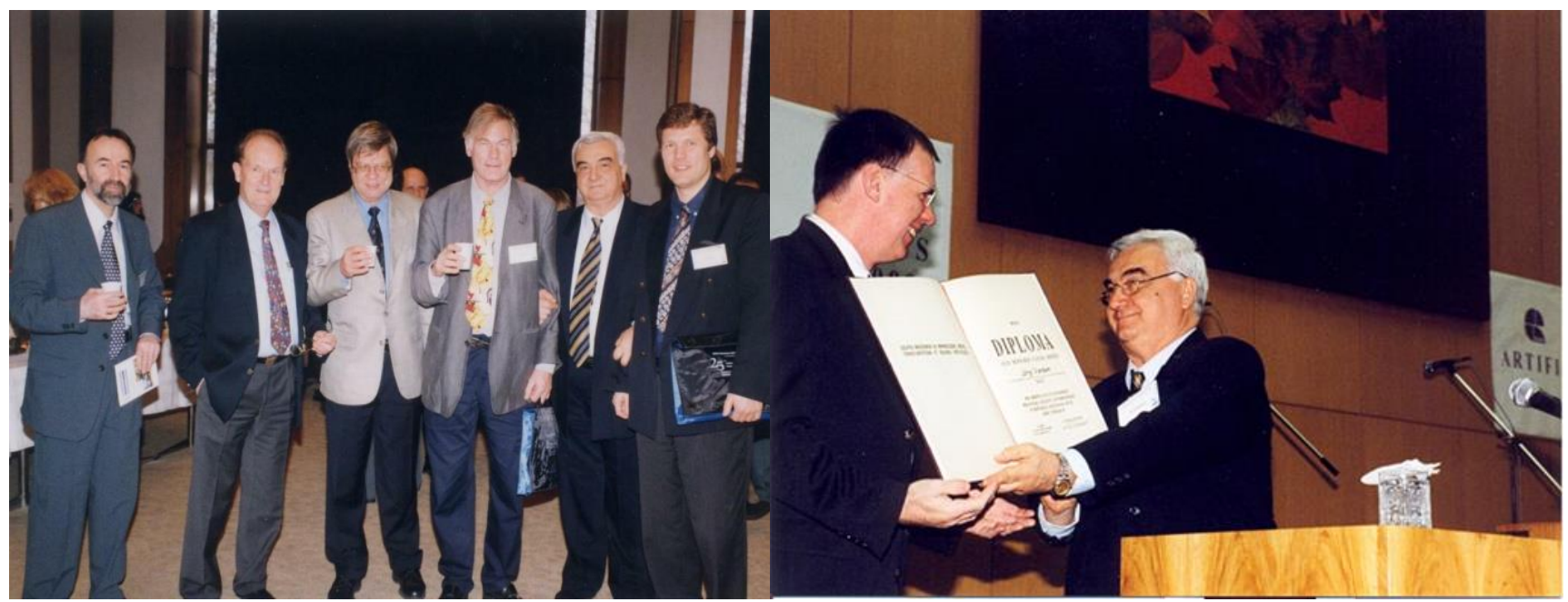

Fig. 32 - Participants at the Symposium for Artificial Organs 2000
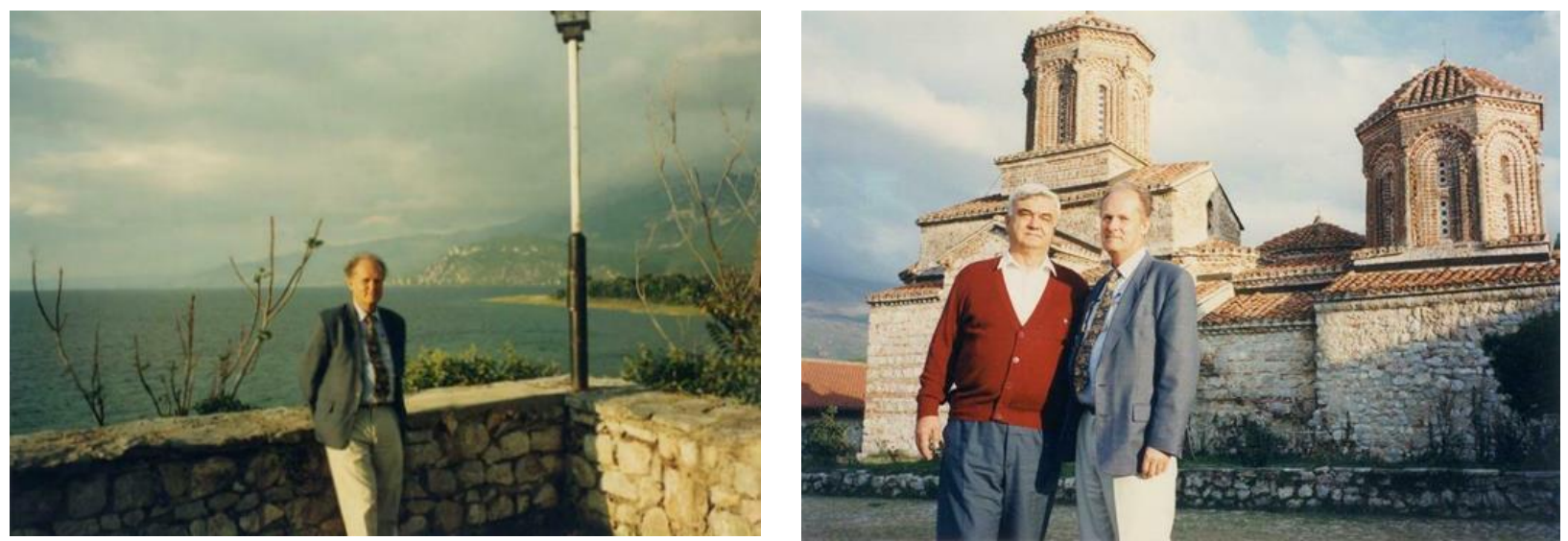

Fig. 33 - H. Klinkmann and M. Polenakovic

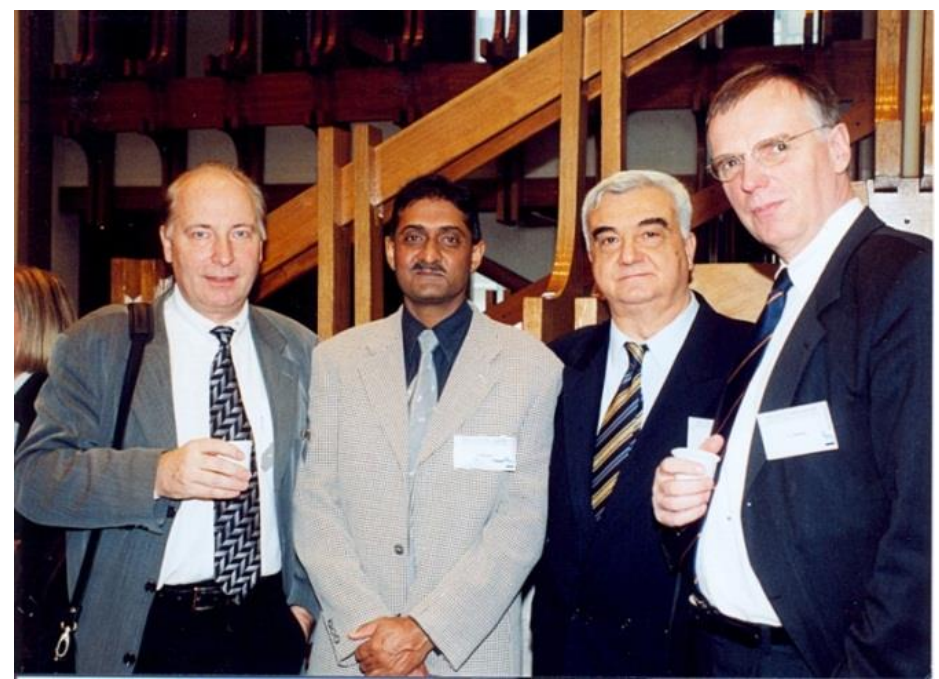

Fig. 34 - Participants at the Symposium for Artificial Organs 2000

M. Polenakovic actively participated in the work of the ERA-EDTA supported CME courses organized in the Republic of Macedonia by G. Spasovski. M. Polenakovic initiated and organized the MacedonianCroatian nephrology meetings, and the last, $7^{\text {th }}$ meeting, was held in 2014 in Skopje. 


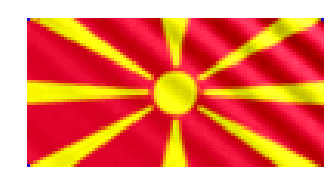

\title{
The incidence of biopsy-proven primary glomerulonephritis in R. Macedonia-long-term follow-up
}

\author{
M. Polenakovic, L. Grcevska, S. Dzikova \\ Department of Nephrology \\ Clinical Centre, Medical Faculty, \\ Skopje - R. Macedonia
}

\section{ПРВИ ХРВА ТСКО-МАКЕДОНСКИ НЕФ Р ОЛОШКИ ДЕНОВИ, СПЛИТ, 12-14 МА J 2006}

Fig. 35 - First Macedonian-Croatian nephrology meeting, Split 2006

\section{Simpozij NEFROLOŠKO UČILIŠTE - 7.12.2013, Zagreb, Hrvatska VI Druženje nefrologa Hrvatske i Makedonije}

Akademik Momir H. Polenaković, Skopje Lekari iz Hrvatske u početnom radu Medicinskog fakulteta u Skoplju,

R. Makedonija 


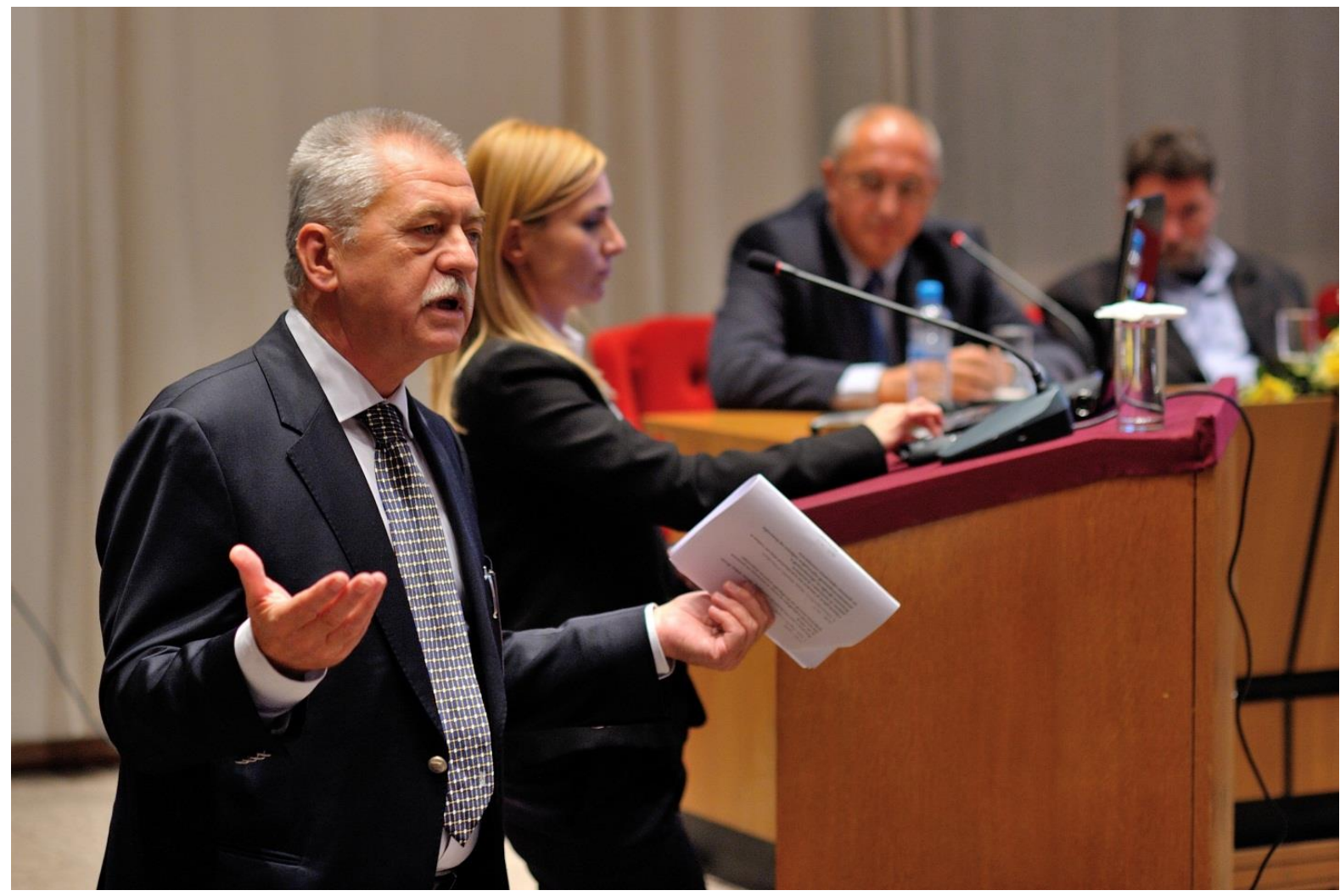

Fig. 37 -P. Kes, Zagreb - Seventh Macedonian-Croatian nephrology meeting, Skopje, 2014

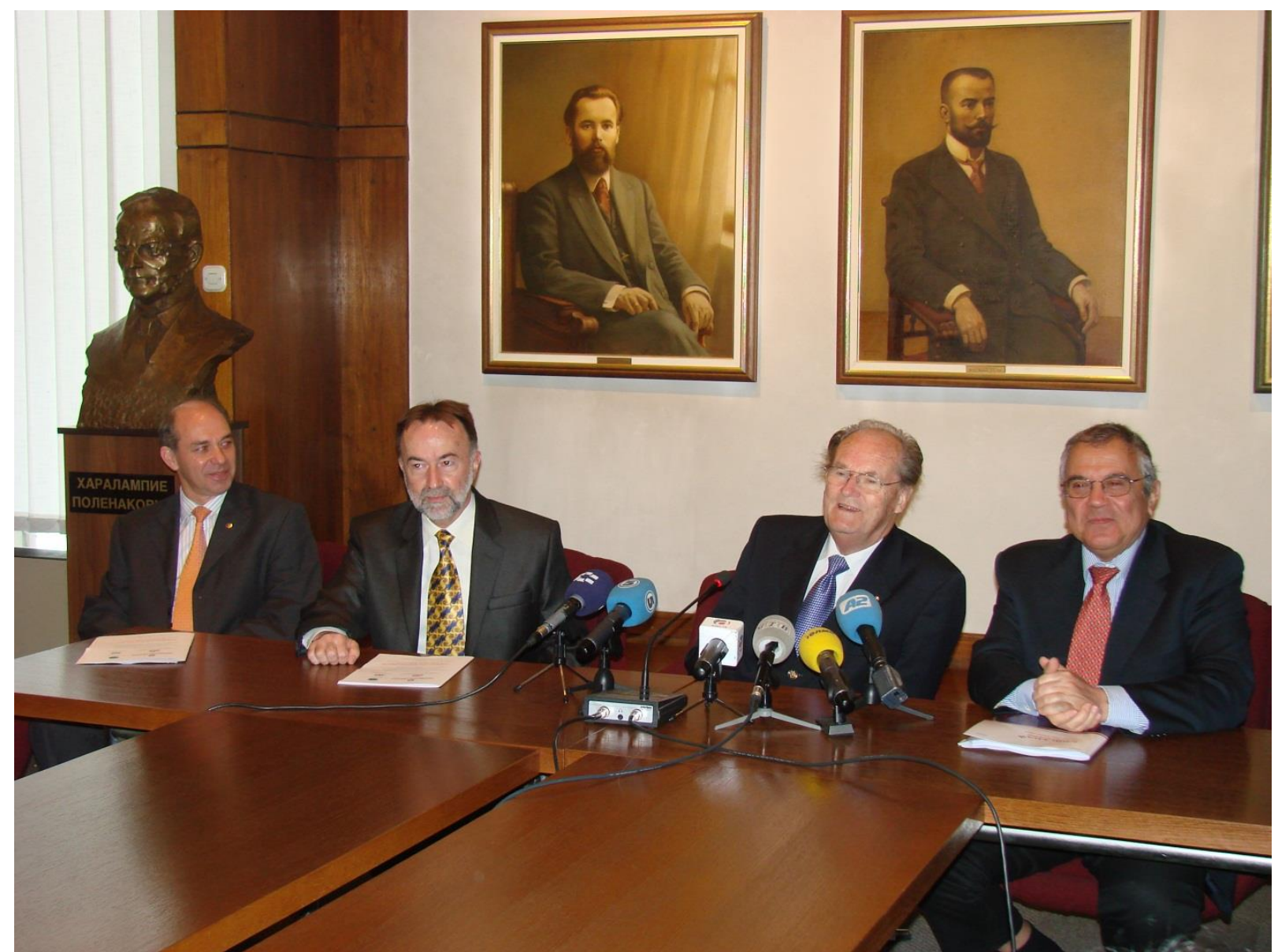

Fig. 38 - Scientific Symposium, Skopje, 2009; From left to right: G. Spasovski (Skopje), A. Sikole (Skopje), H. Klinkmann (Rostock), G. London (Paris) 
A great success was also the organization of the ESAO Congress in 2010 at the Macedonian Academy of Sciences and Arts.

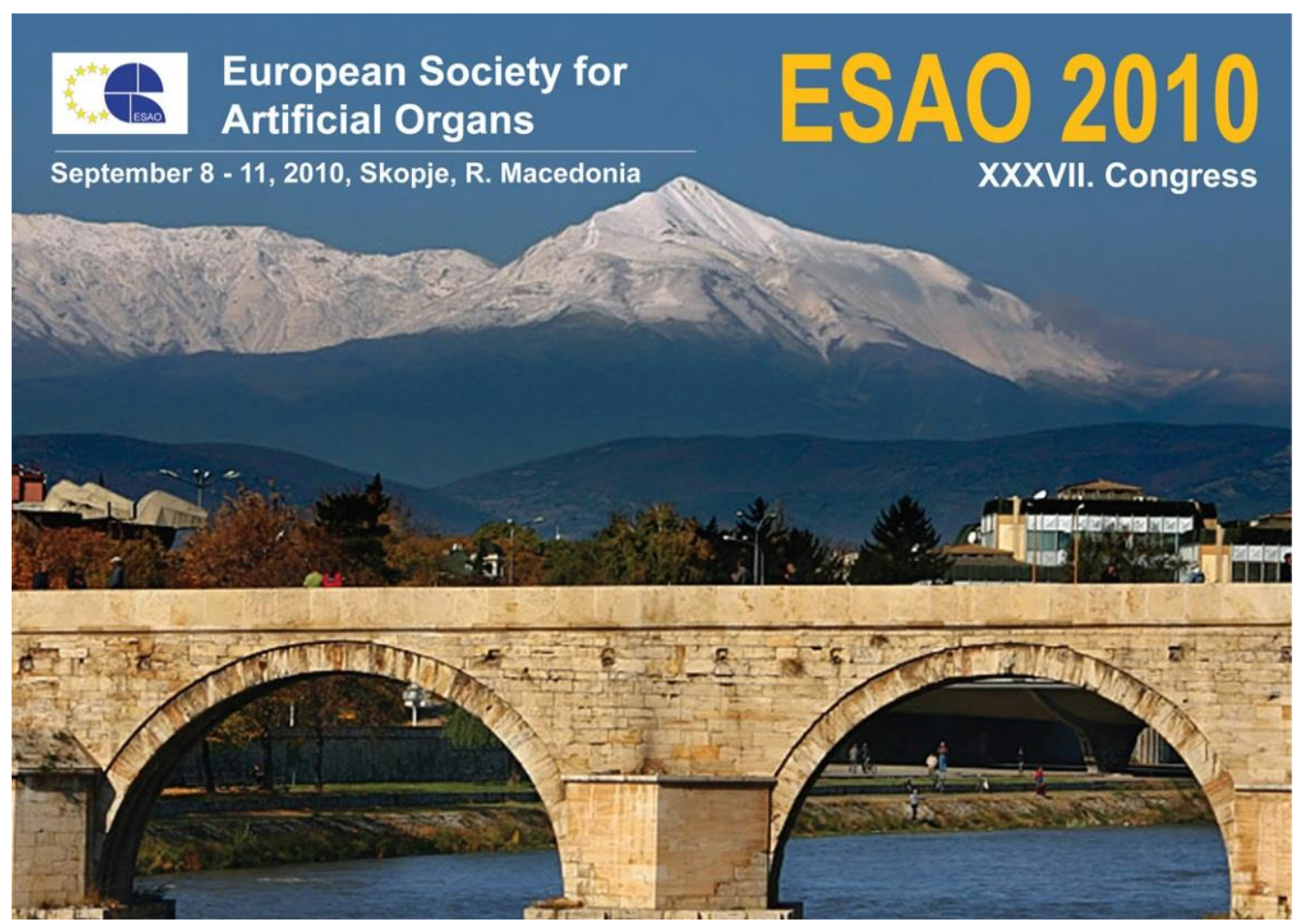

Fig. 39 - ESAO Congress 2010 at the Macedonian Academy of Sciences and Arts

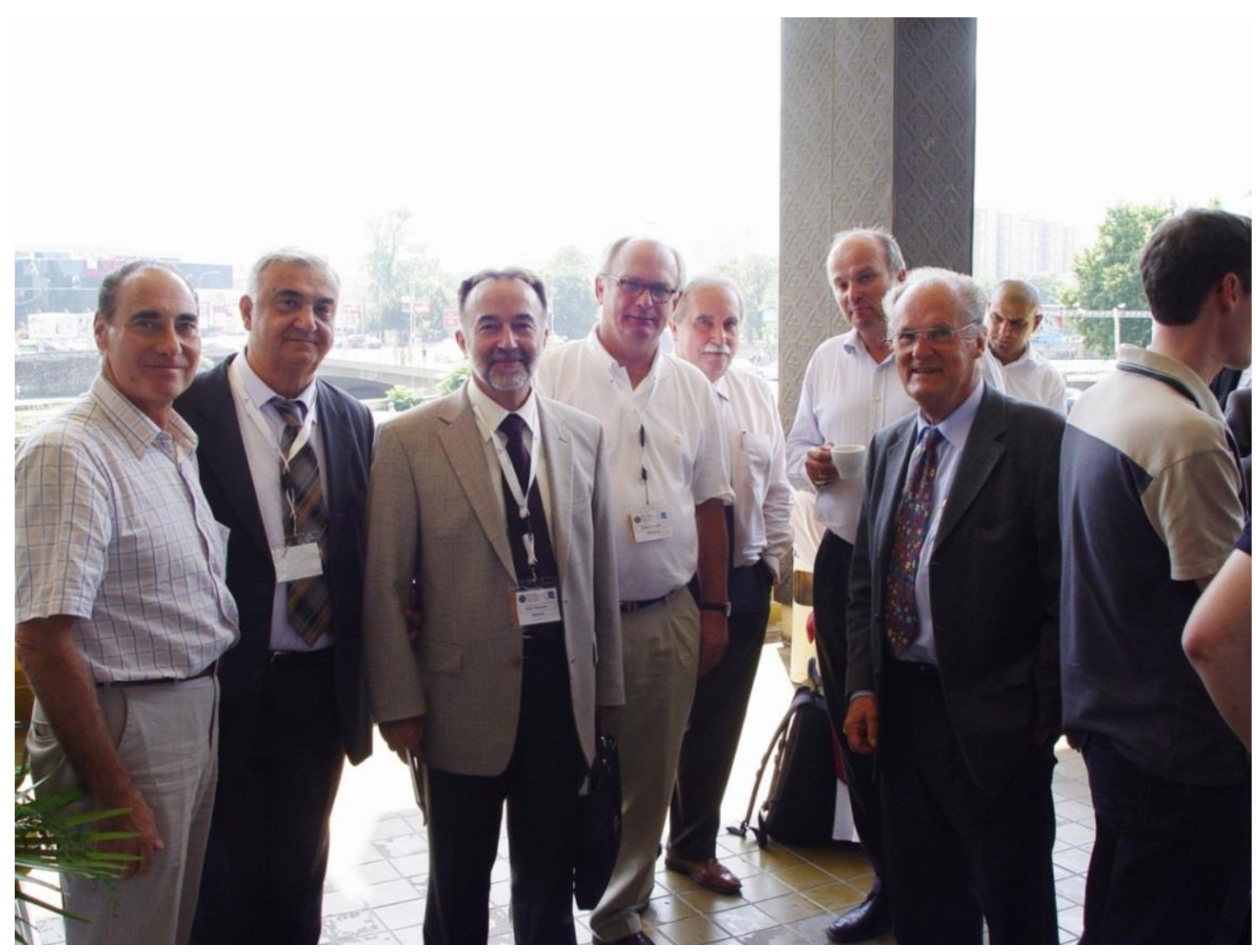

Fig. 40 - Participants at the ESAO Congress 2010 at the Macedonian Academy of Sciences and Arts 


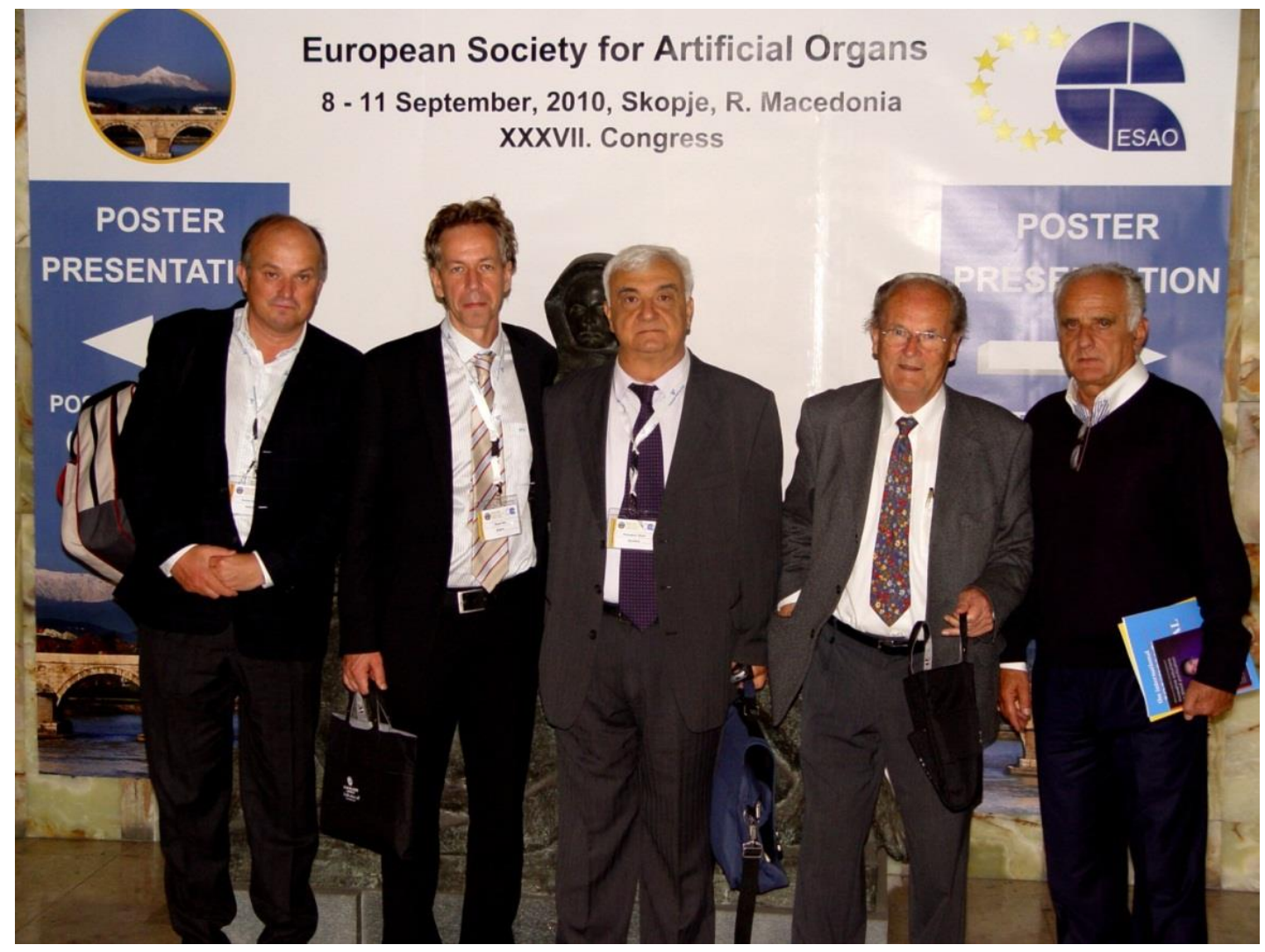

Fig. 41 - ESAO Congress 2010 at the Macedonian Academy of Sciences and Arts

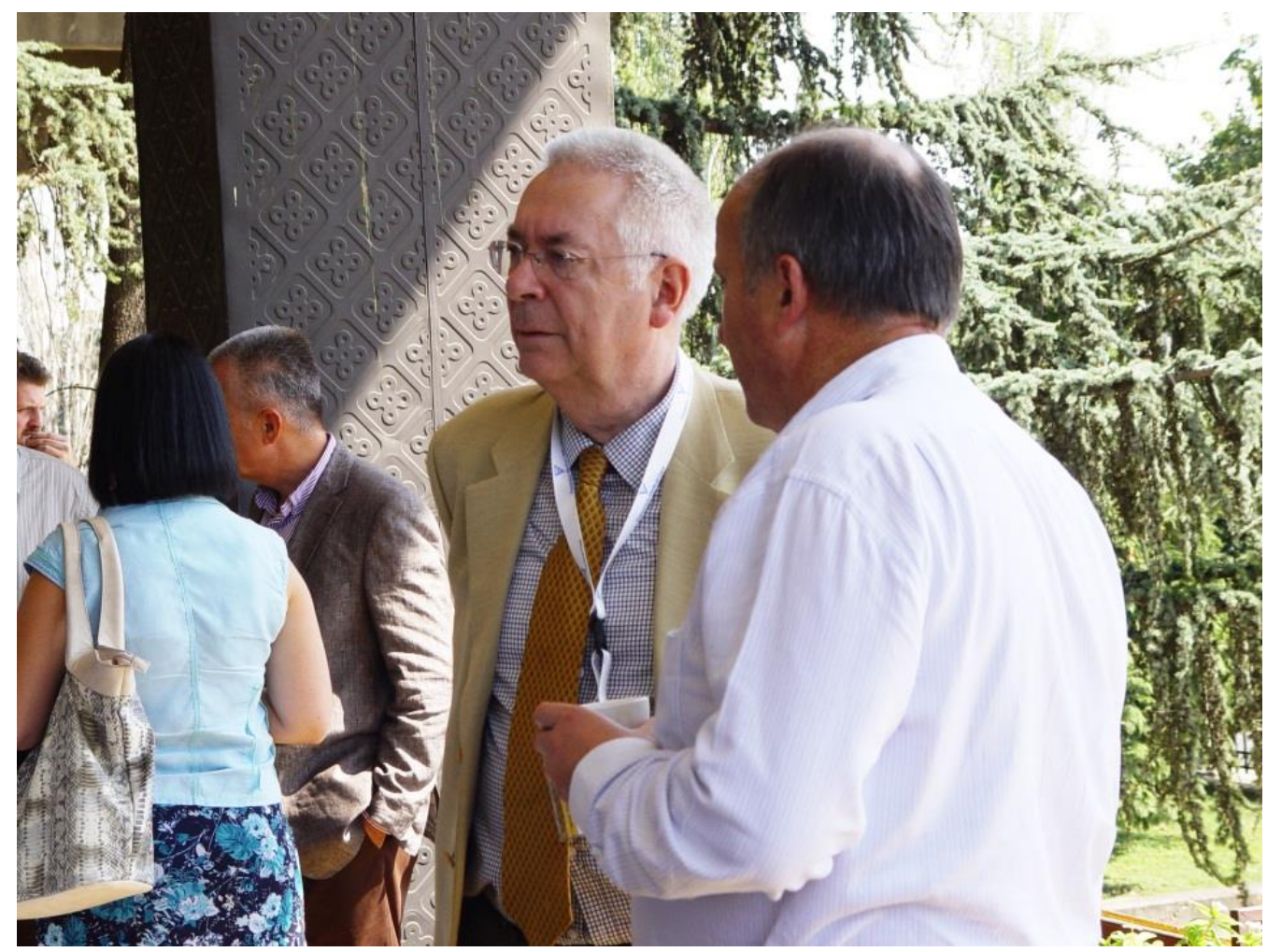

Fig. 42 - H. Mann

M. Polenakovic was very active in the work of the MSNDTAO in collaboration with the societies from Albania, Bulgaria, Kosovo and Serbia. In 2012, at the IV Congress of the MSNDTAO M. Polenakovic was elected Honorary lifetime President of the MSNDTAO. 


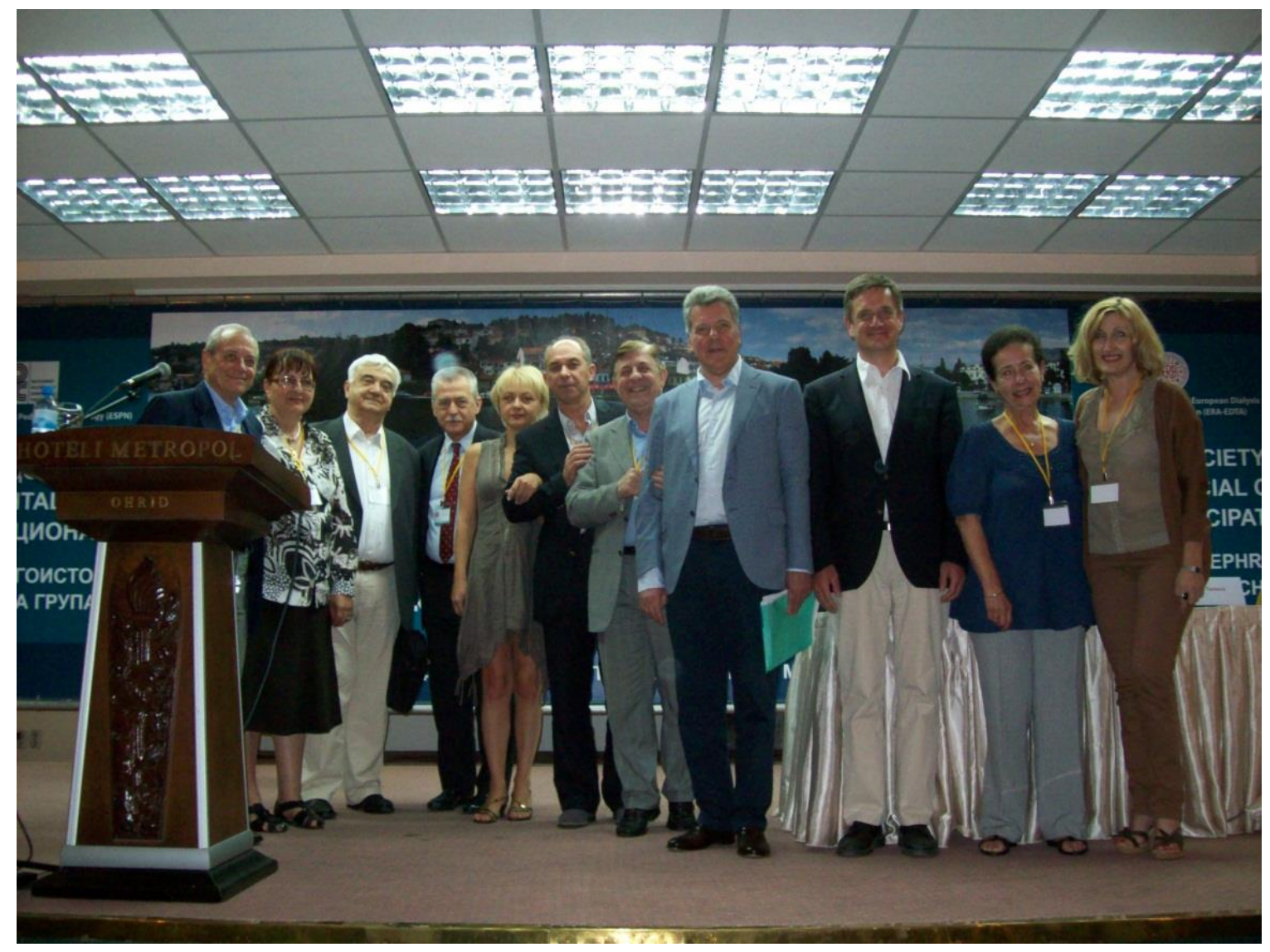

Fig. 43 - Participants at the IV Congress of the MSNDTAO

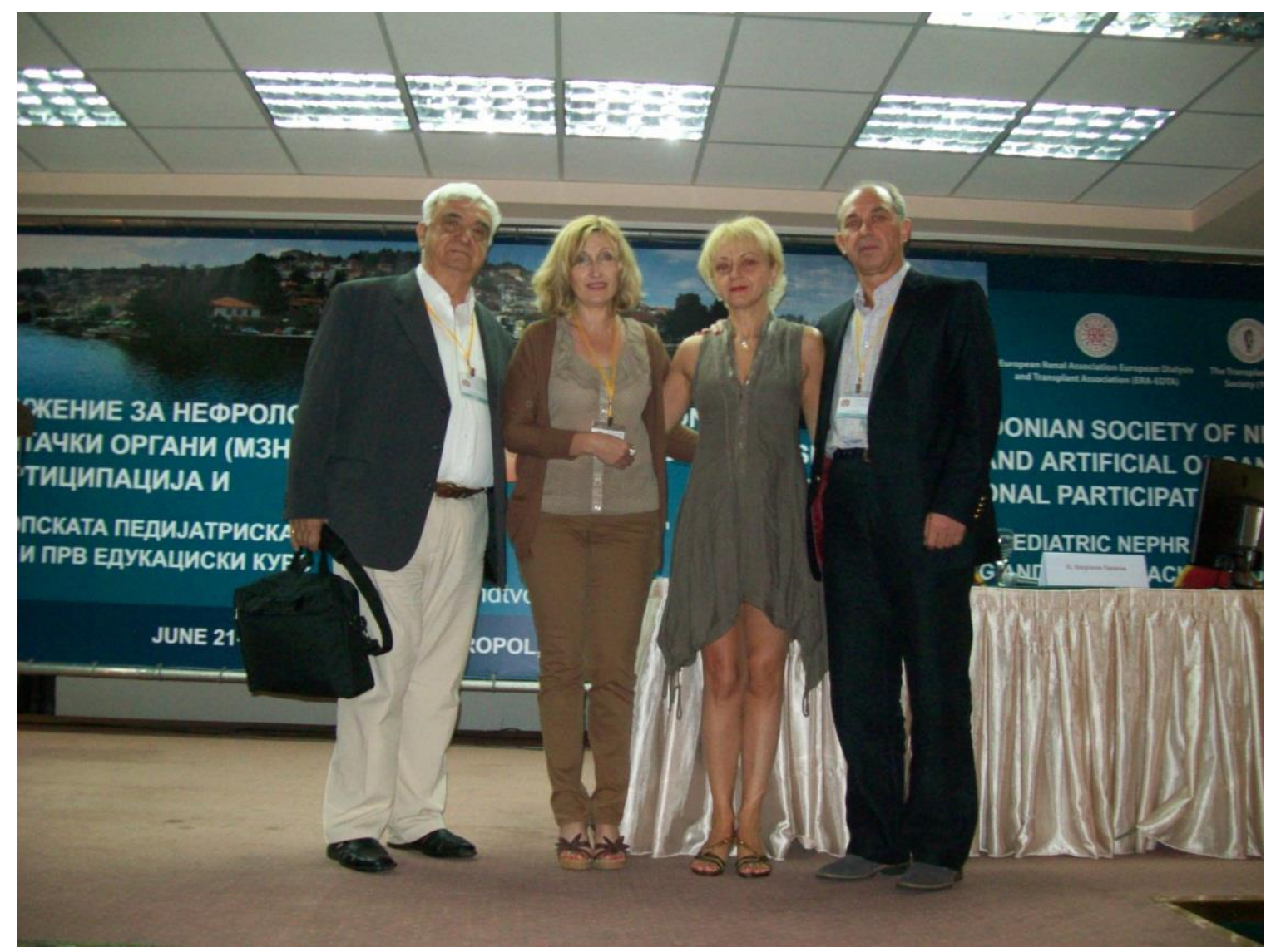




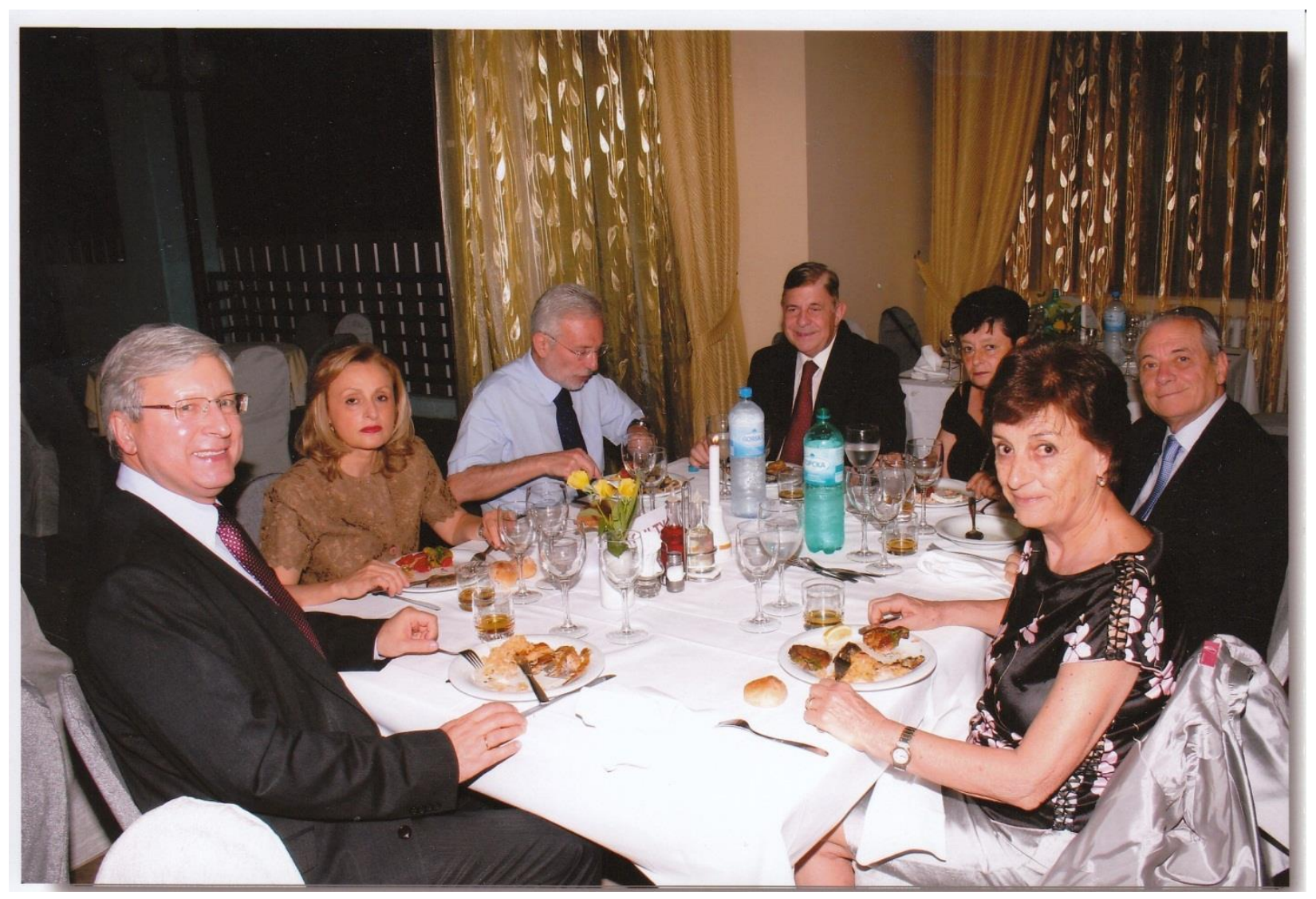

Fig. 45 - IV Congress of the MSNDTAO

From left to right: A. Wiecek (Poland), F. Mallamaci (Italy), C. Zoccali (Italy), F. Locatelli (Italy), P. Schena (Italy)

In April 2014 M. Polenakovic with his colleagues established the Macedonian Association of Medical Editors, and he was elected President of the Association.

M. Polenakovic organized and co-organized three meetings on Rare Diseases in South
Eastern Europe, with the participation of renowned experts from the Balkans and Europe.

M. Polenakovic has been awarded a number of recognitions and awards. 

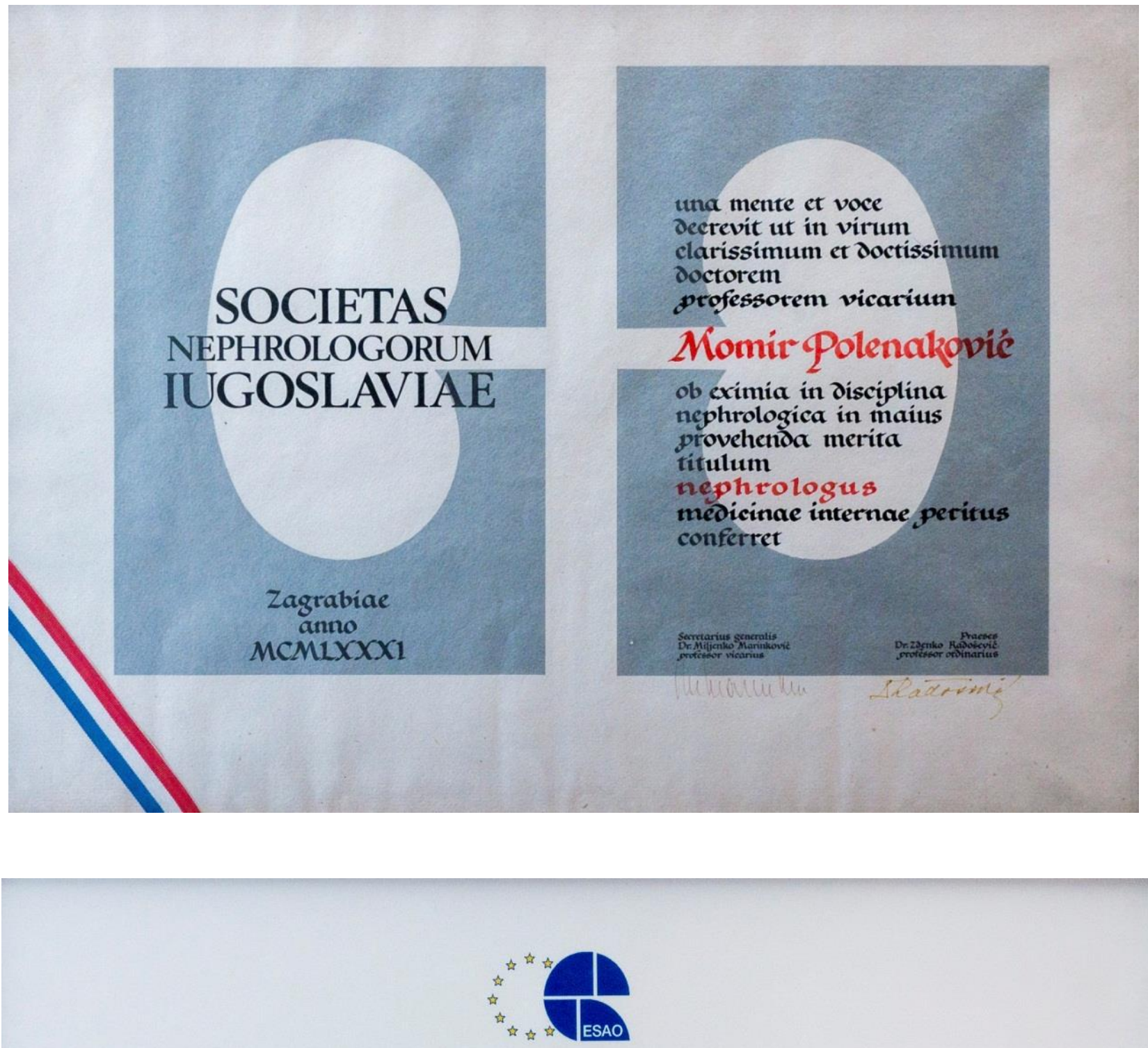

The European Society for Artificial Organs

sincerely thanks

\section{Prof. Momir Polenakovic, MD}

in recognition of his services in the

\section{Board of Governors}

$1997-2005$

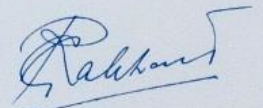

Prof. Gerhard Rakhorst DVM President
Prof. Heinrich Schima, PhD Secretary General 

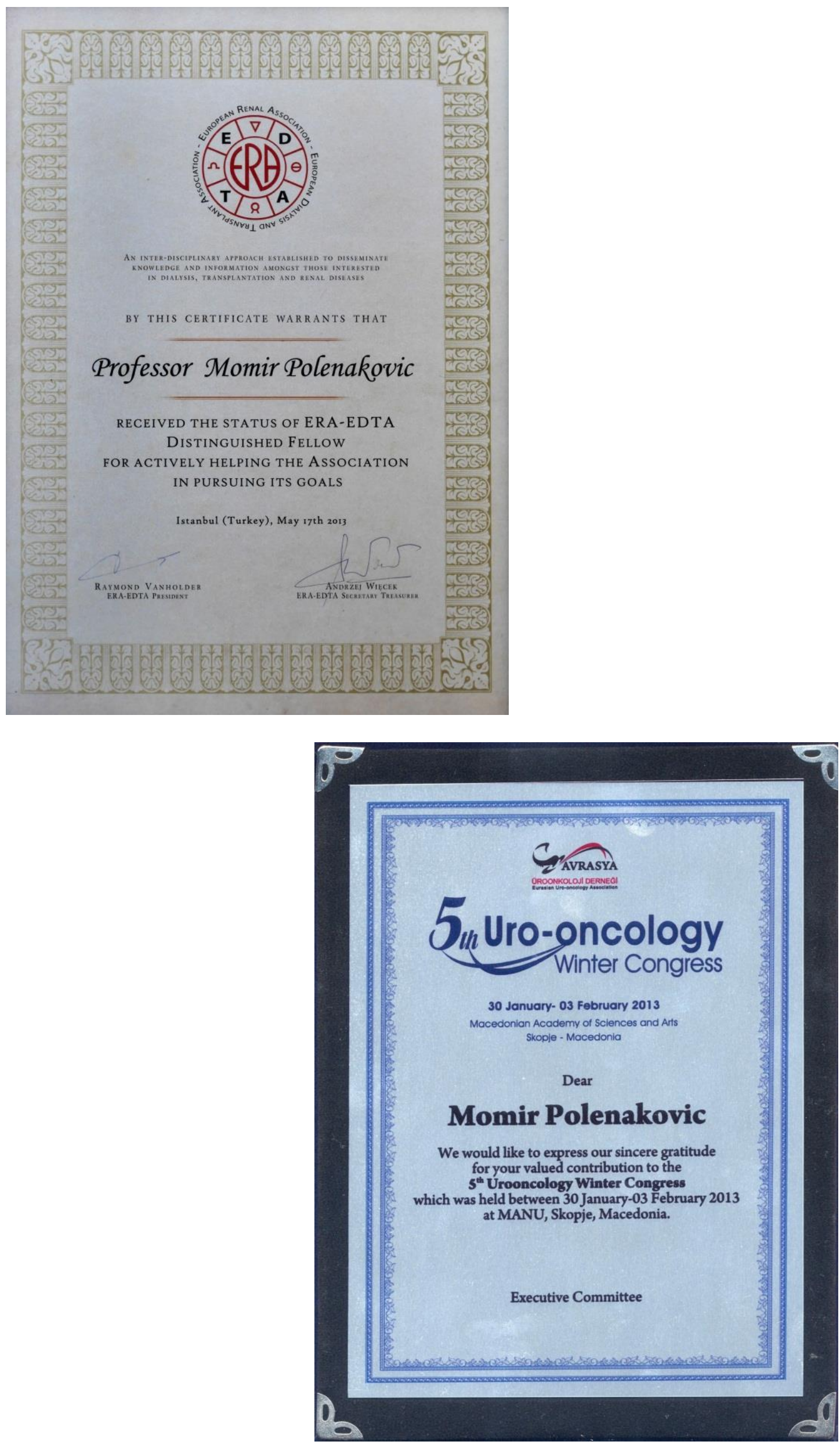

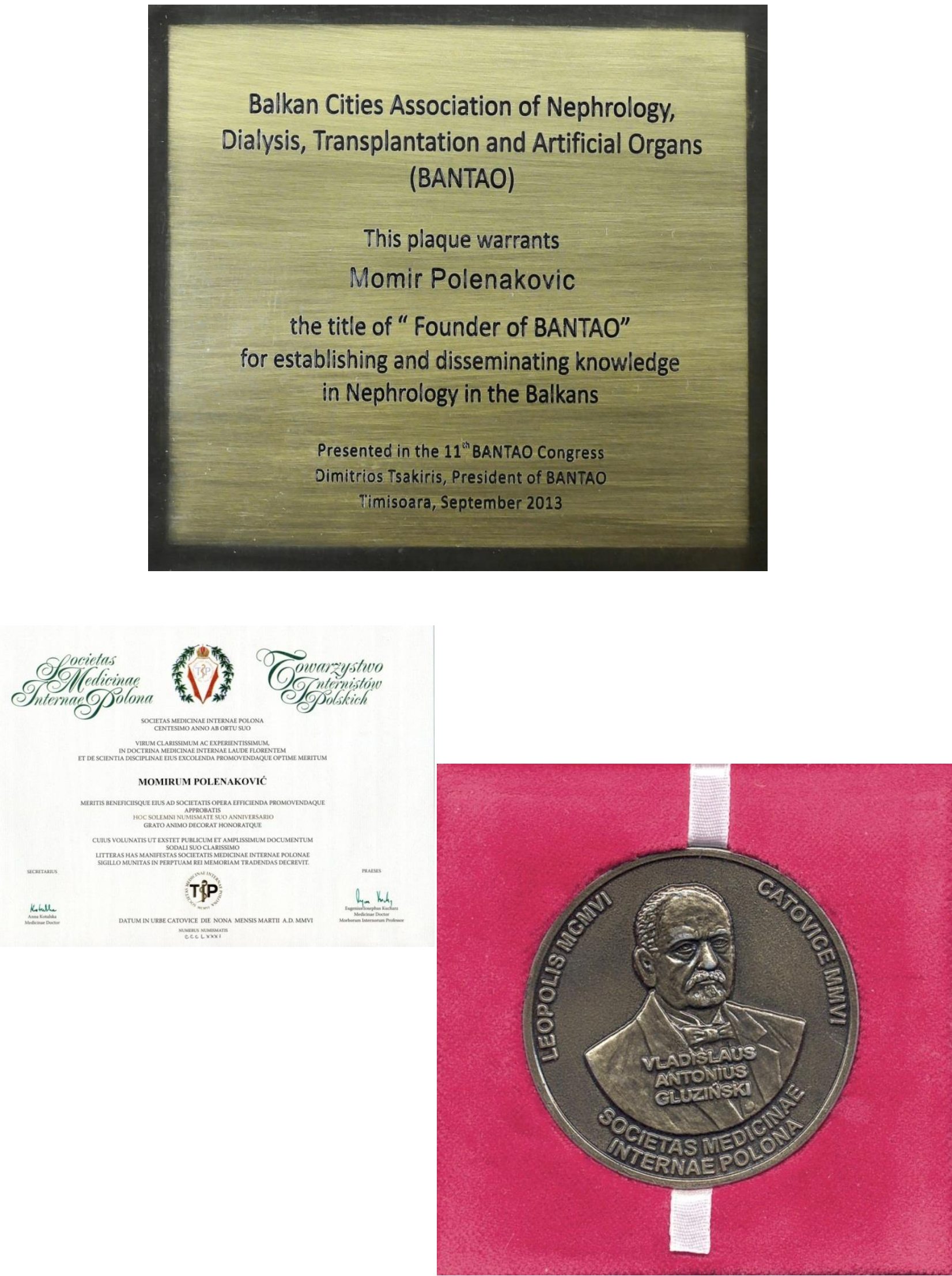

During the ISN Congress in Hong Kong, China in 2013, the International Society of Nephrology for the first time awarded the nephrologists from different parts of the world for their pioneering activity and achievements in the field of nephrology. Acad. M. Polenakovic was awarded the ISN Pioneer Award for the region of Central and Eastern Europe. 


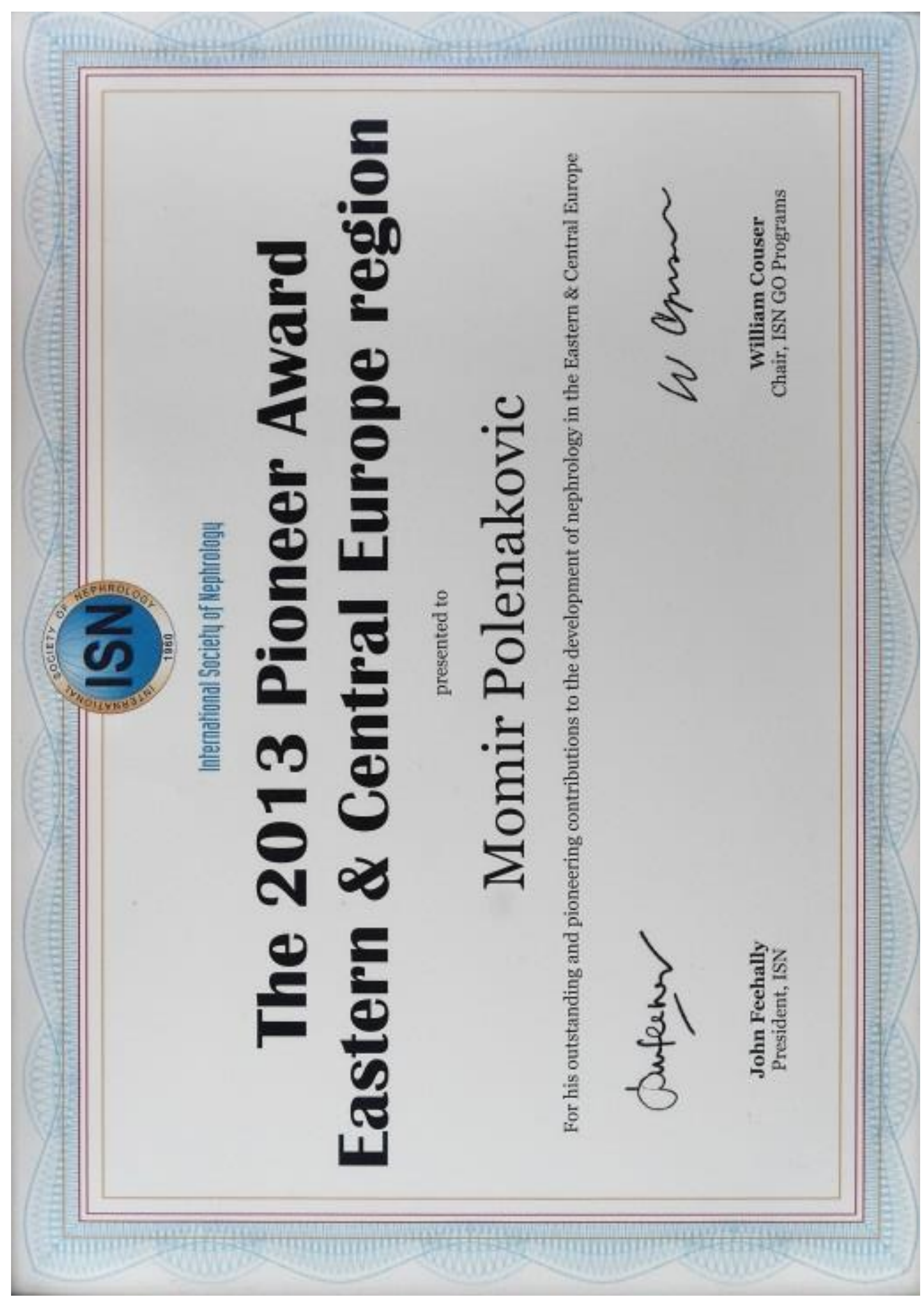




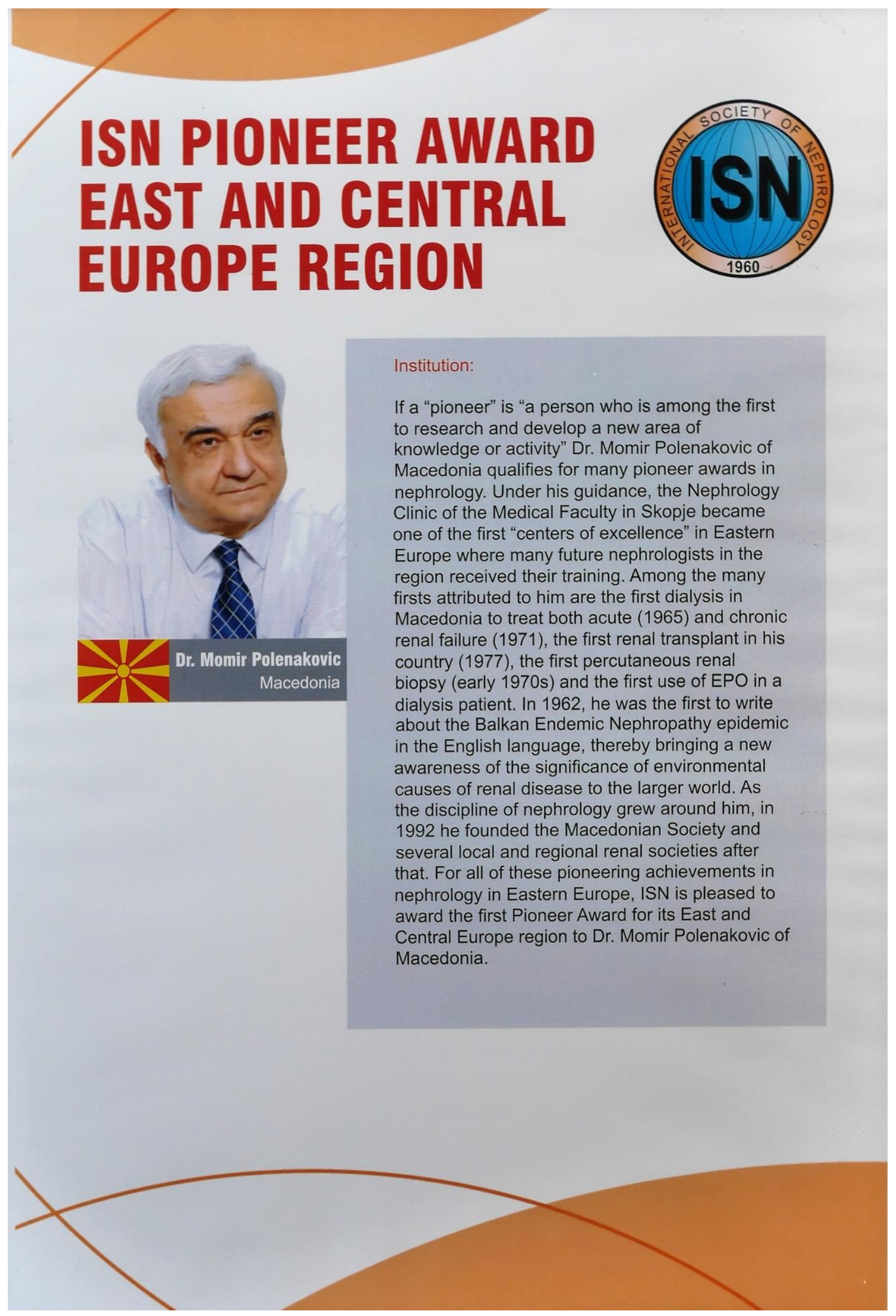




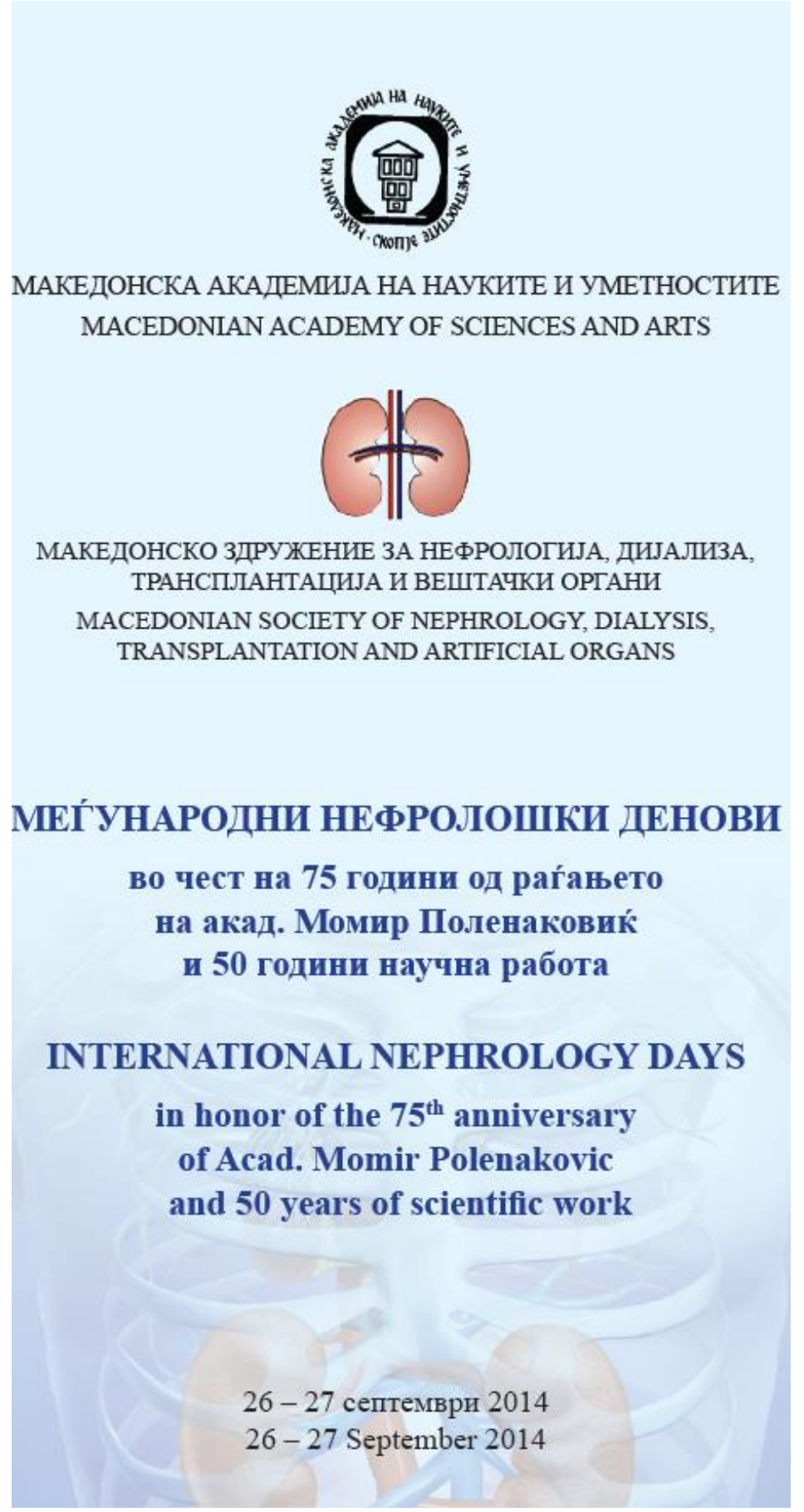

On September 26-27, 2014, International Nephrology Days were organized in honor of the 75th anniversary of Acad. Momir Polenakovic and 50 years of his scientific work. During the meeting, the VII Macedonian-Croatian Nephrological Meeting and the ERA-EDTA CME Course Renal Replacement Therapy When \& How - Update on the Outcome and Cost-Efficacy were held, with participants from the Macedonian Academy of Sciences and Arts (V. Kambovski and V. Serafimoski), Bulgarian Academy of Sciences (A. Galabov, D. Ton- cheva), Serbian Academy of Sciences and Arts (V. Stefanovic), and participants from Europe and the USA: C. Wagner (Switzerland), H. Polenakovik (USA), H. Klinkmann (Germany), $\mathrm{H}$. Mischak (Germany), P. Kes (Croatia), D. Abramowicz (Belgium), A. Wiecek (Poland), P. Schena (Italy), R. Ponikvar (Slovenia), S. Racki (Croatia), R. Vanholder (Belgium), G. Spasovski, (Republic of Macedonia), C. Zoccali (Italy), A. Basci (Turkey), G. Rosoklija (USA), M. Barbullushi (Albania), S. Simic-Ogrizovic (Serbia), J. Buturovic-Ponikvar (Slovenia). 


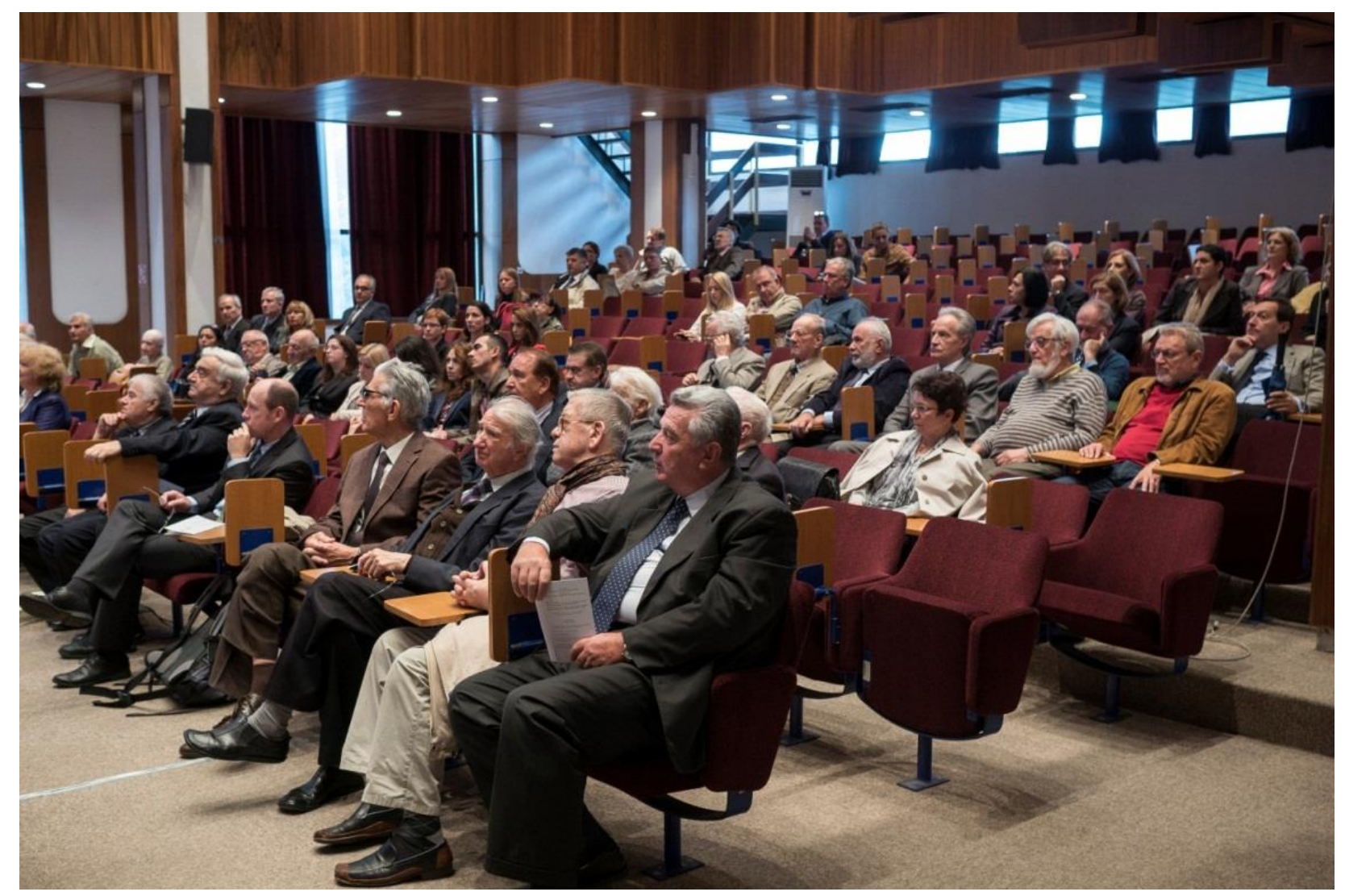

Fig. 46 - Participants at the International Nephrology Days - 2014

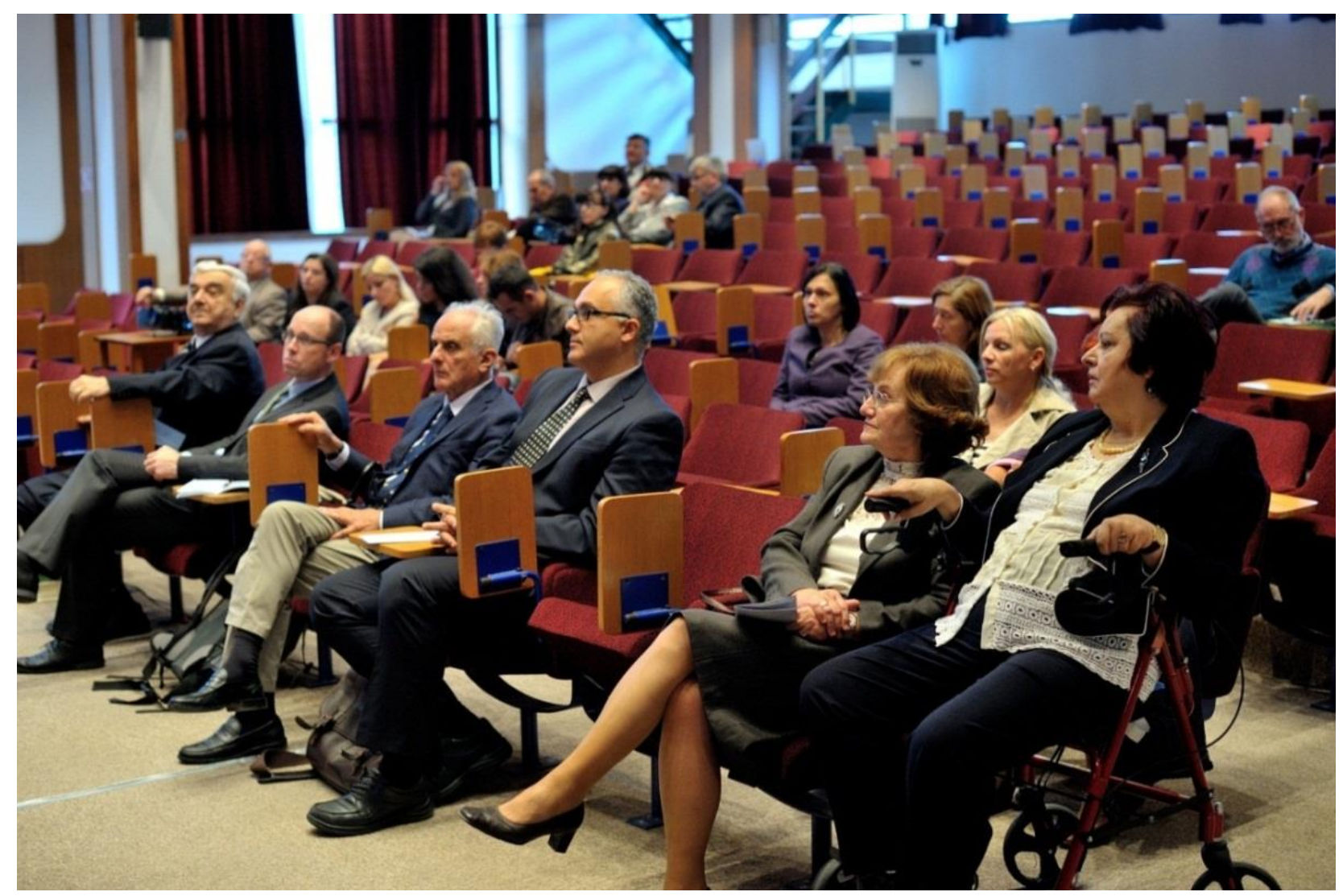

Fig. 47 - Participants at the International Nephrology Days - 2014 


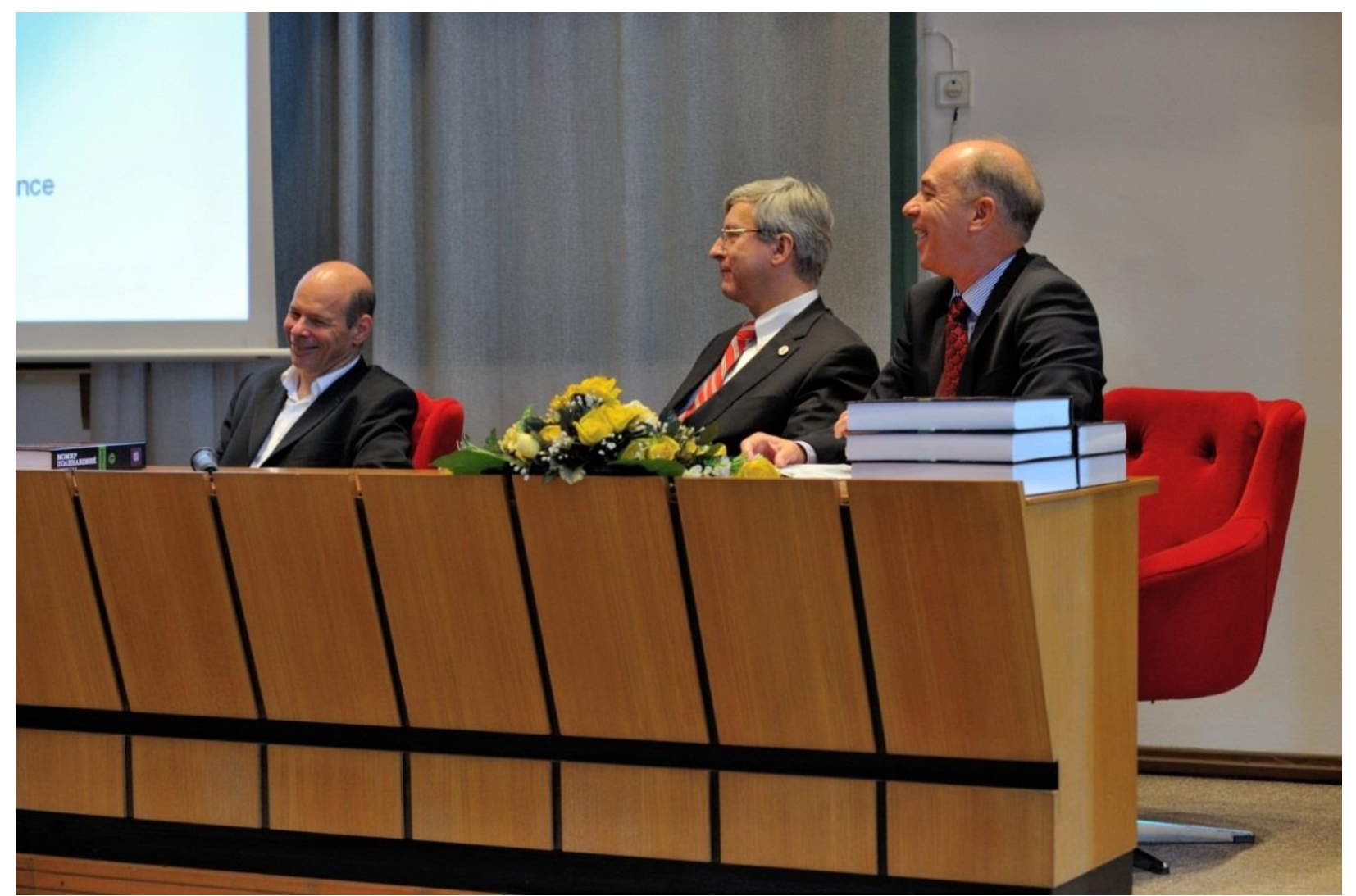

Fig. 48 - Promotion of the collected papers of M. Polenakovic

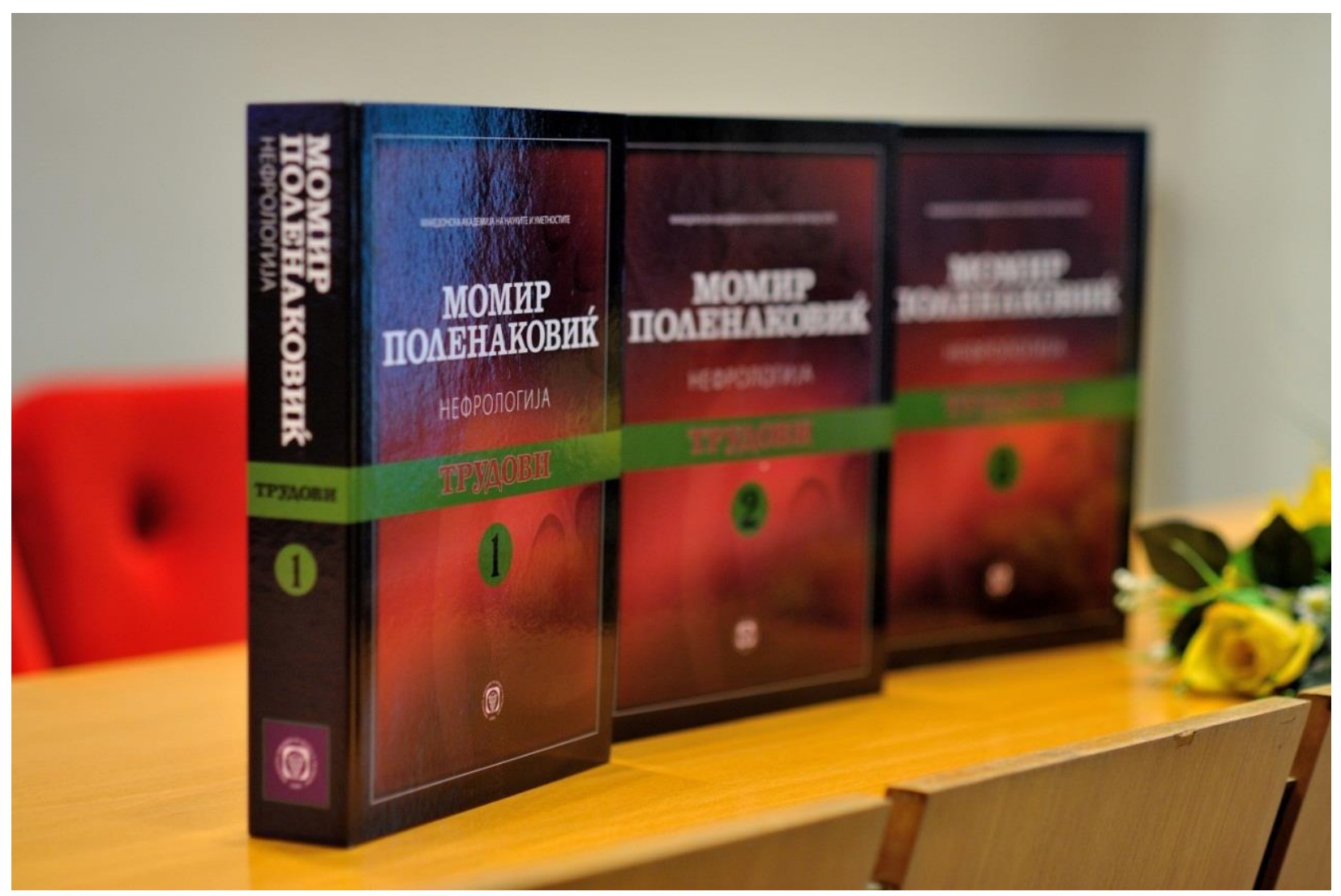

Fig. 49 - Promotion of the collected papers of M. Polenakovic 


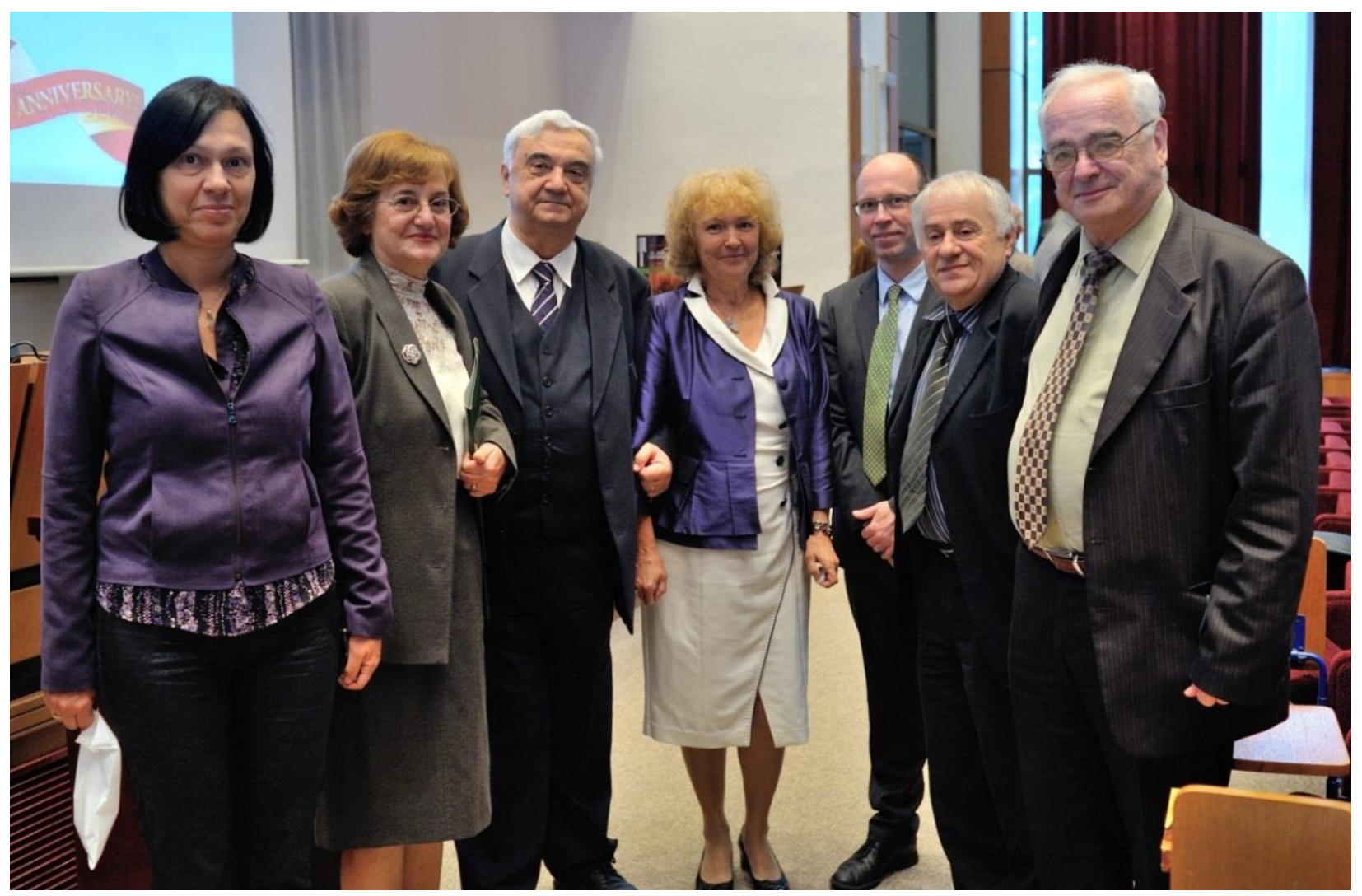

Fig. 50 - Participants at the International Nephrology Days - 2014

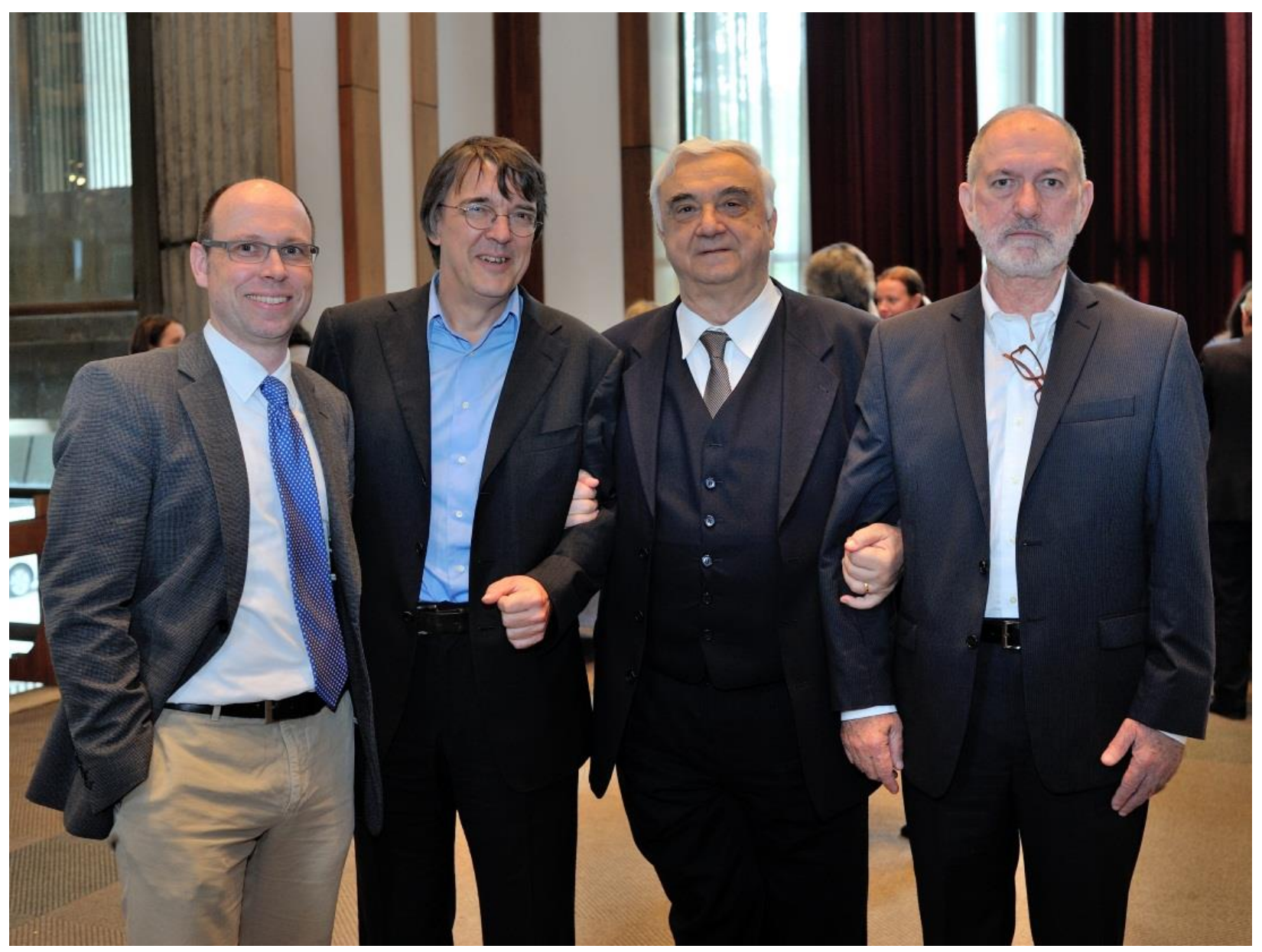

Fig. 51 - Participants at the International Nephrology Days - 2014 


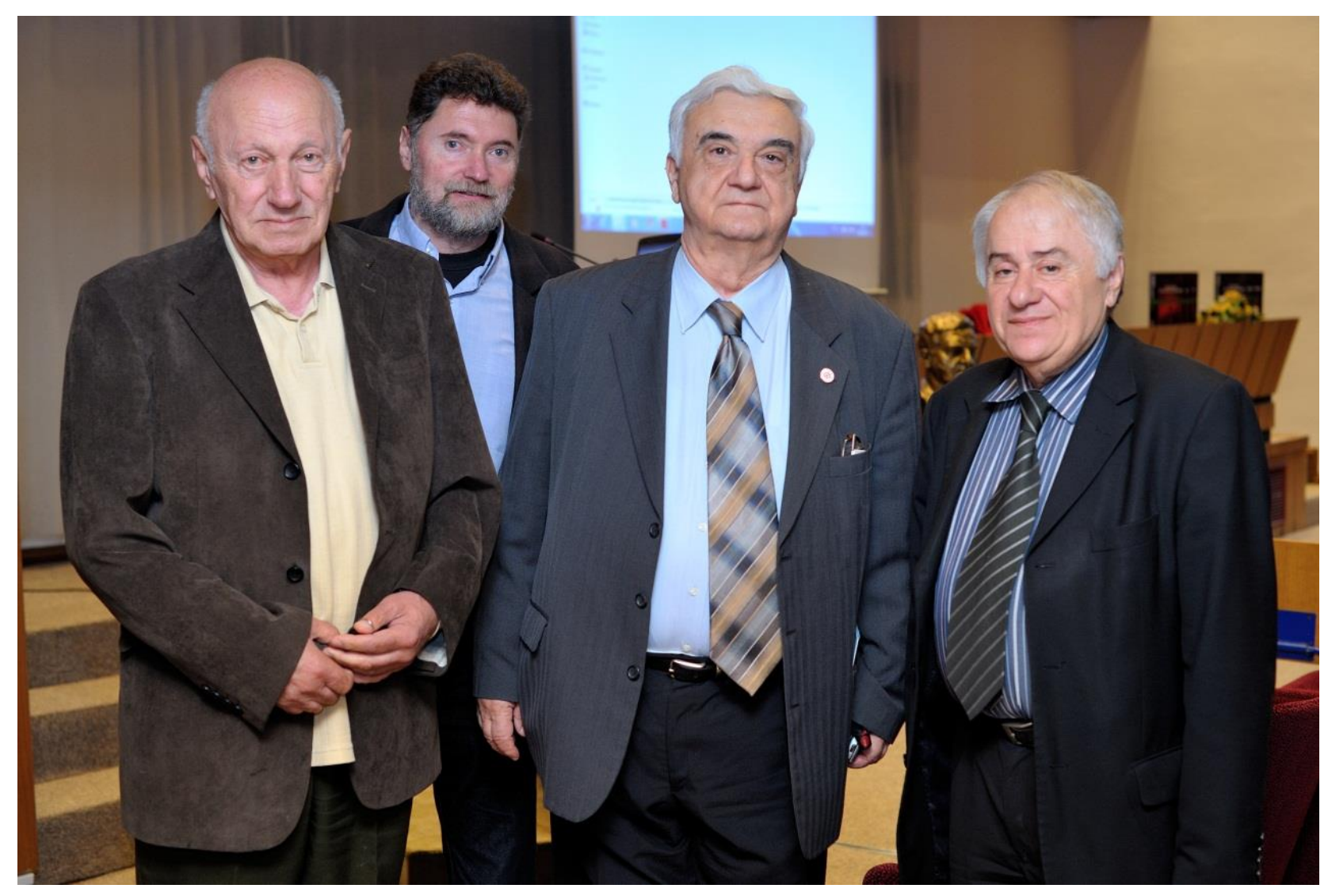

Fig. 52 - Participants at the International Nephrology Days - 2014 


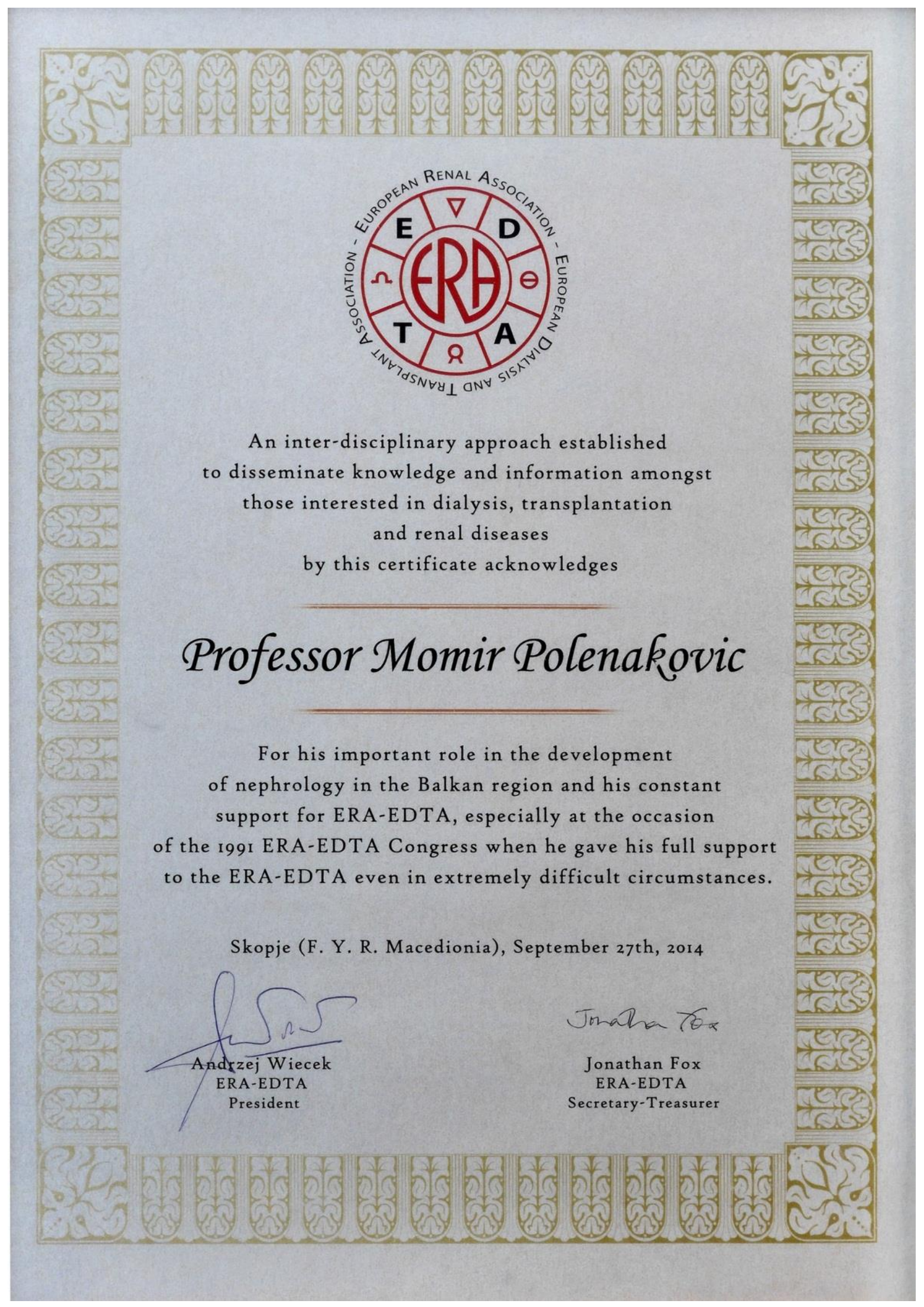

Acad. M. Polenakovic was also awarded a Certificate of the ERA-EDTA for his important role in the development of nephrology in the Balkan region and his constant support for
ERA-EDTA. The Certificate was presented by Prof. A. Wiecek, President of European Renal Association (ERA-EDTA) 


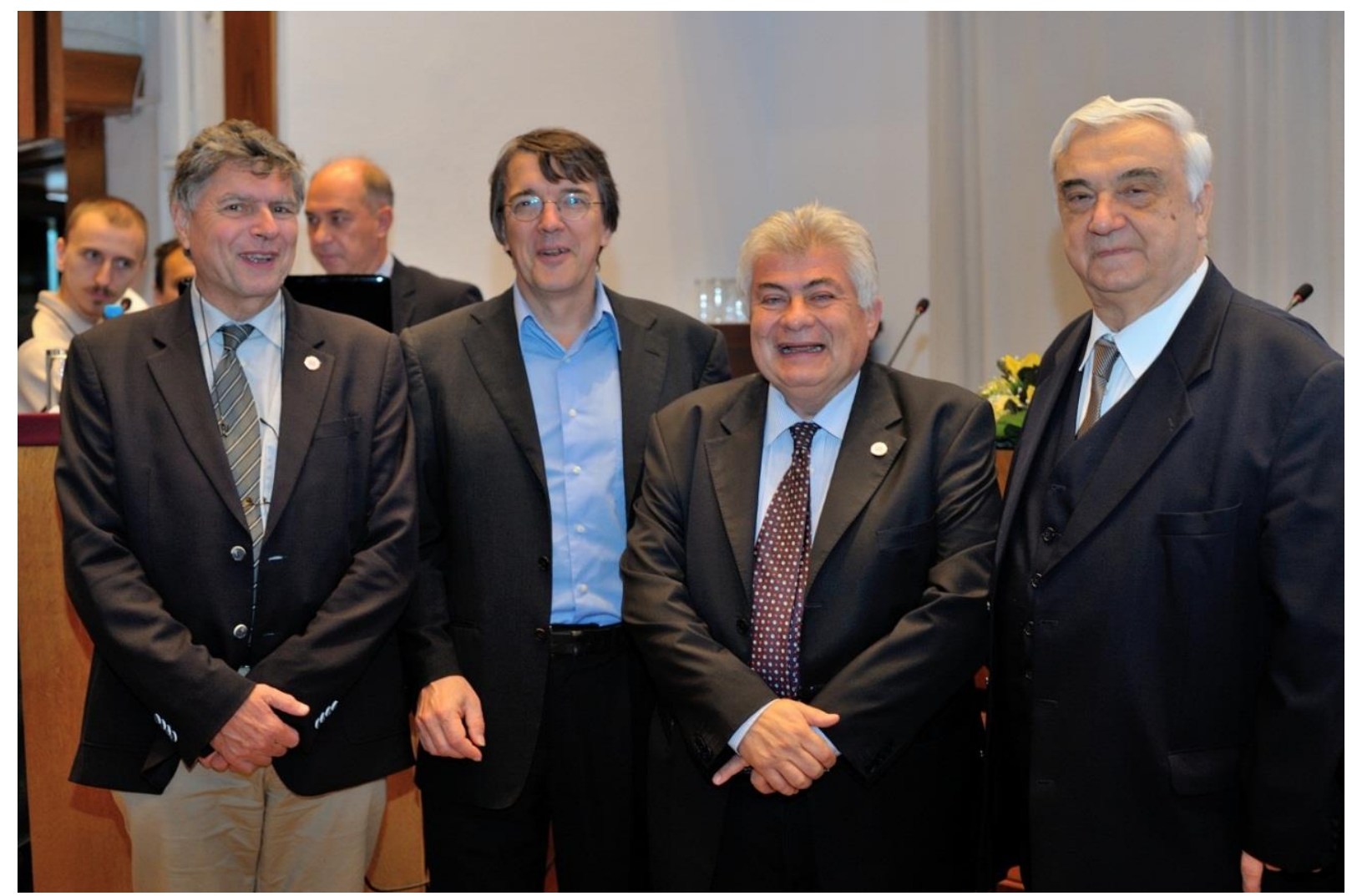

Fig. 53 - R. Van Holder, H. Mischak, A. Basci and M. Polenakovic - International Nephrology Days in honor of the 75th anniversary of Acad. Momir Polenakovic and 50 years of scientific work, September 2014

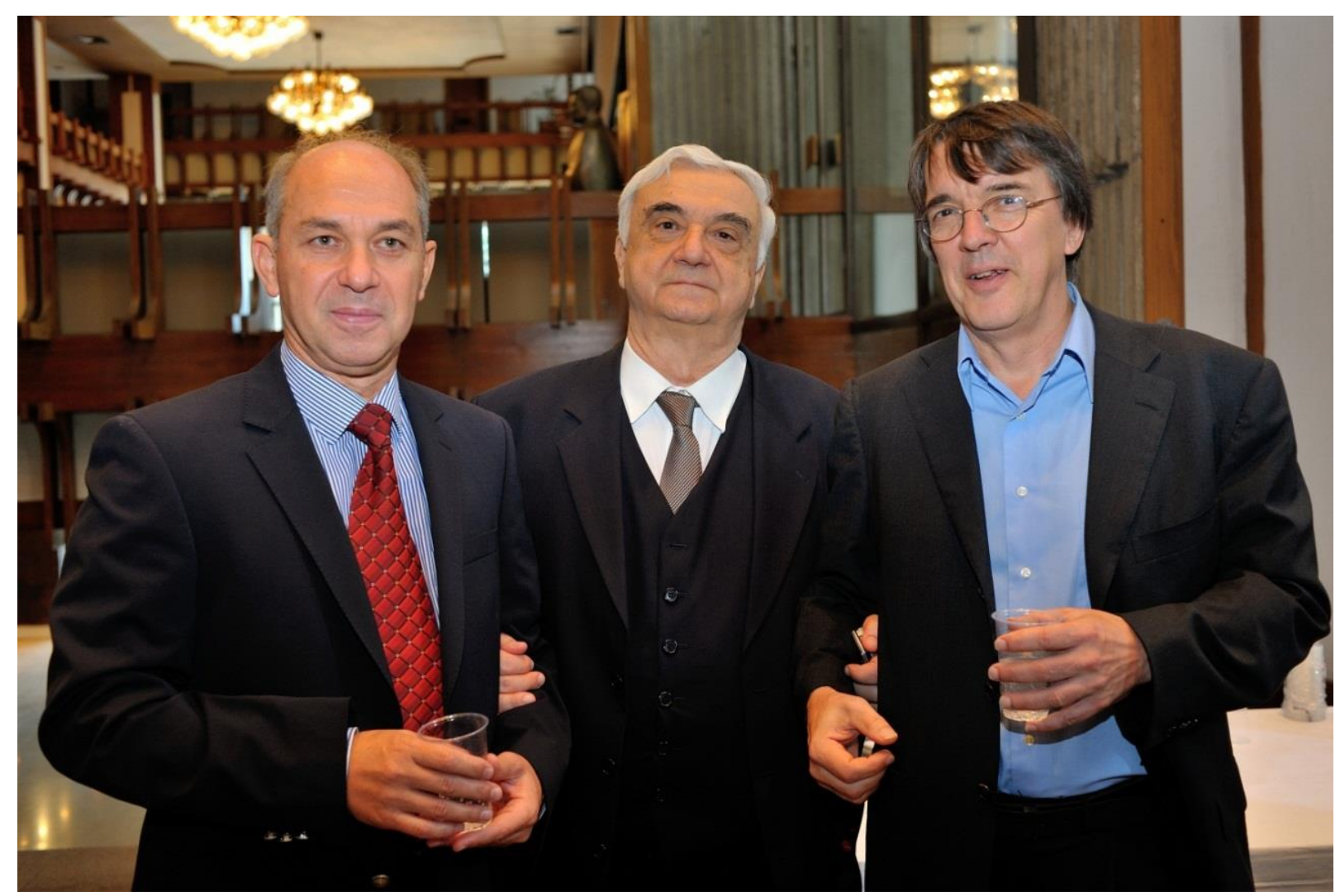

Fig. 54 - G. Spasovski (Skopje), M. Polenakovic (Skopje), H. Mischak (Hanover) 

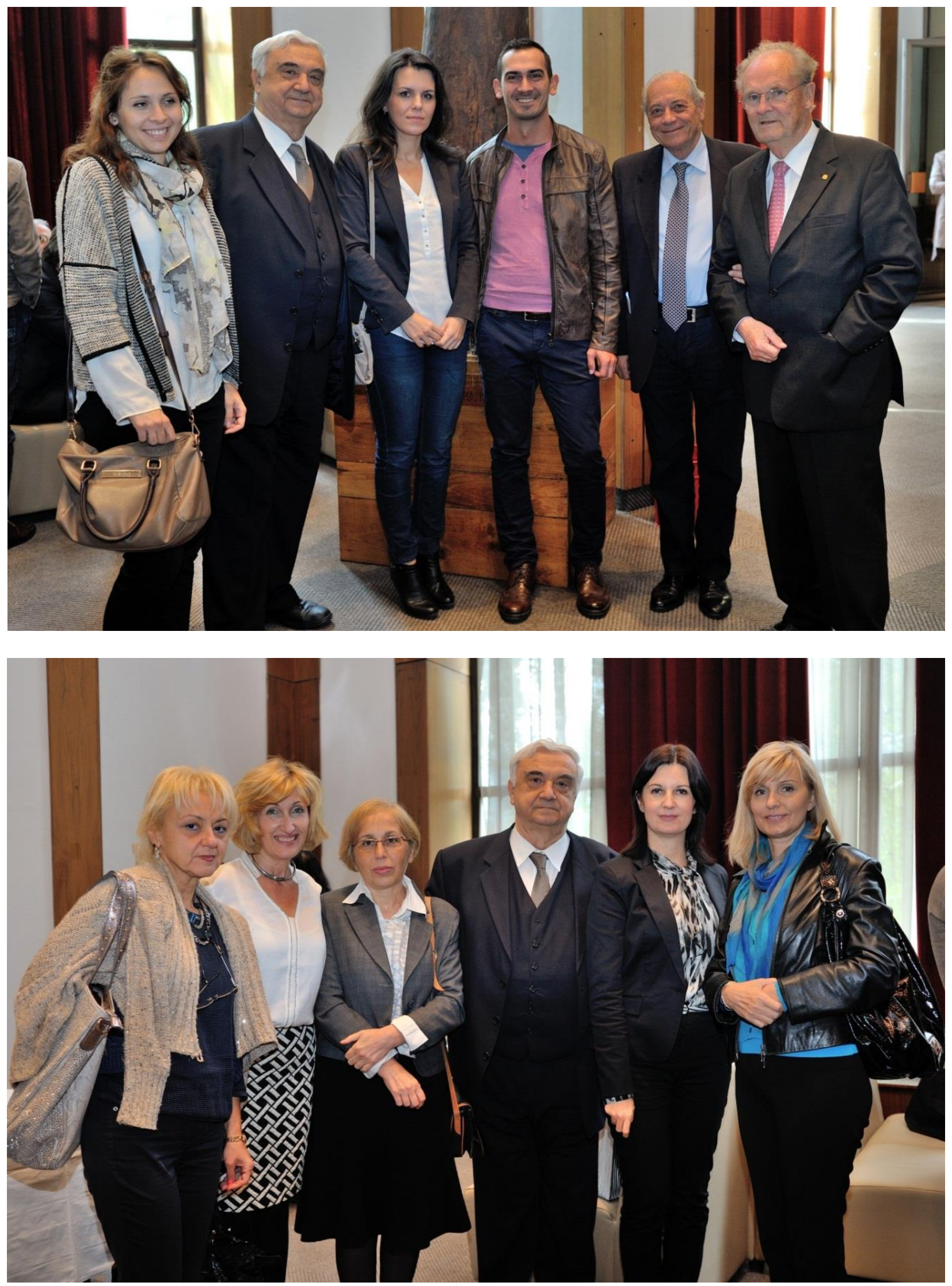

Fig. 55 - Participants at the International Nephrology Days - 2014 

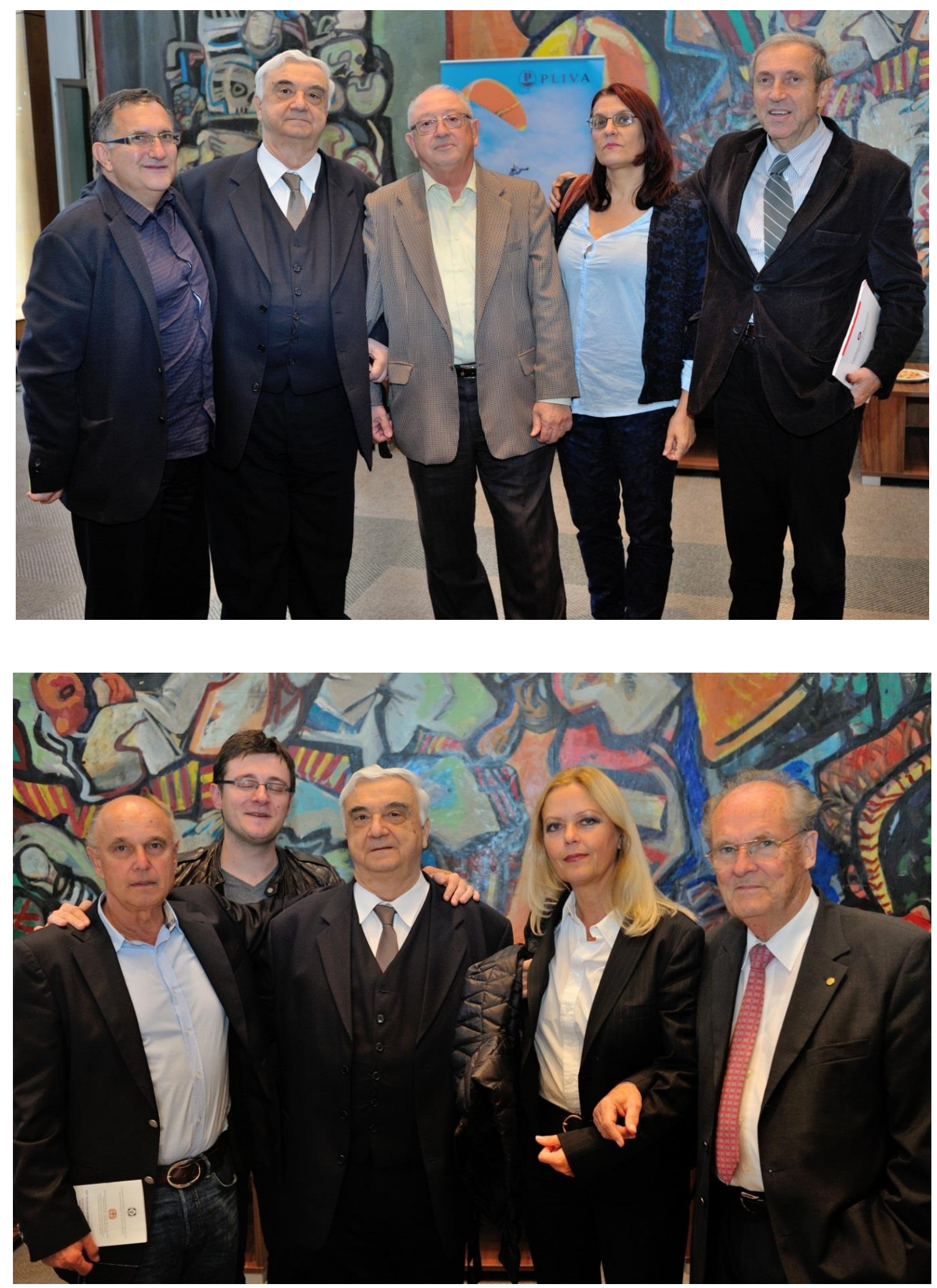

Fig. 56 - Participants at the International Nephrology Days - 2014 


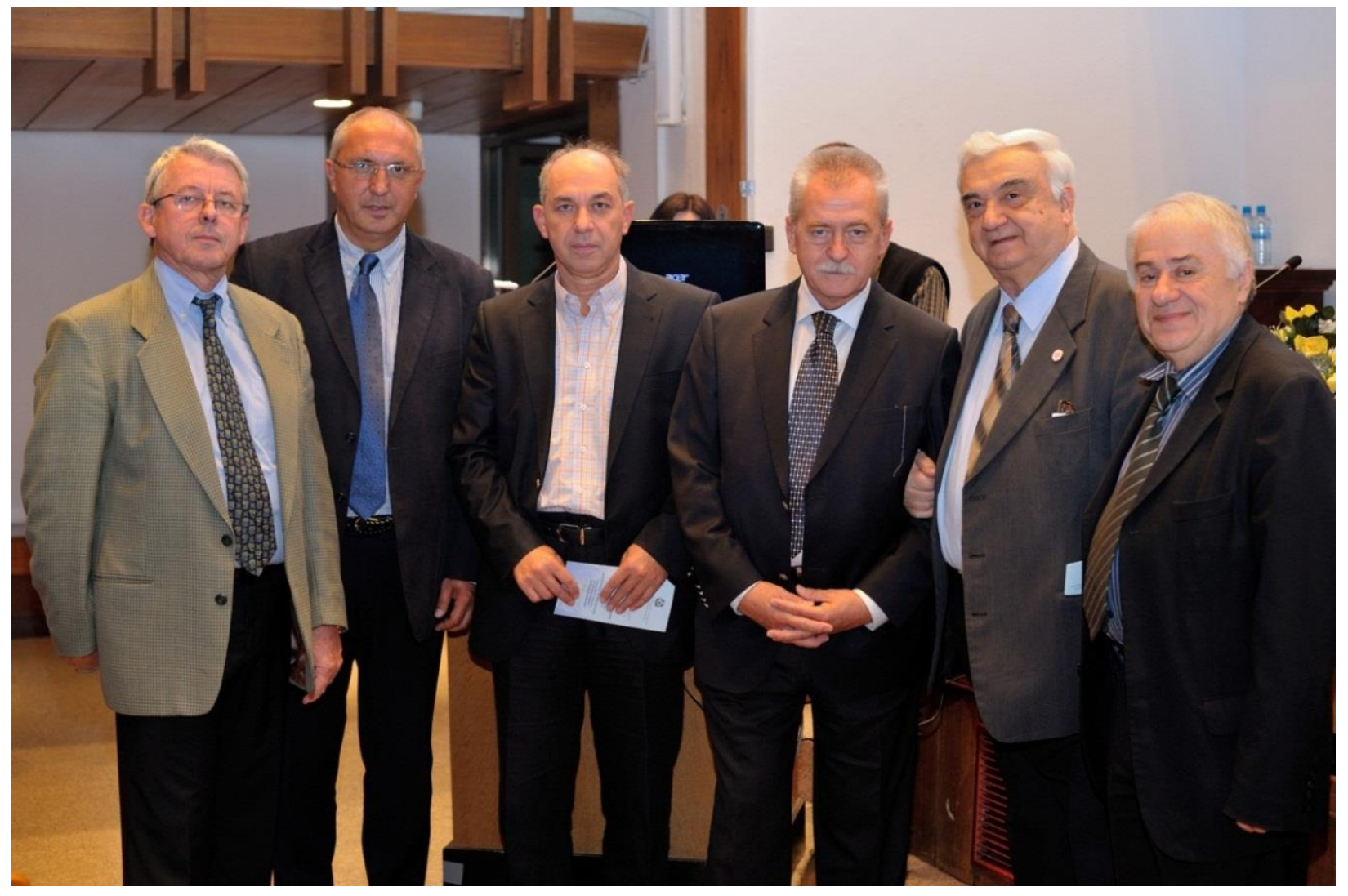

Fig. 57 - Participants at the International Nephrology Days - 2014

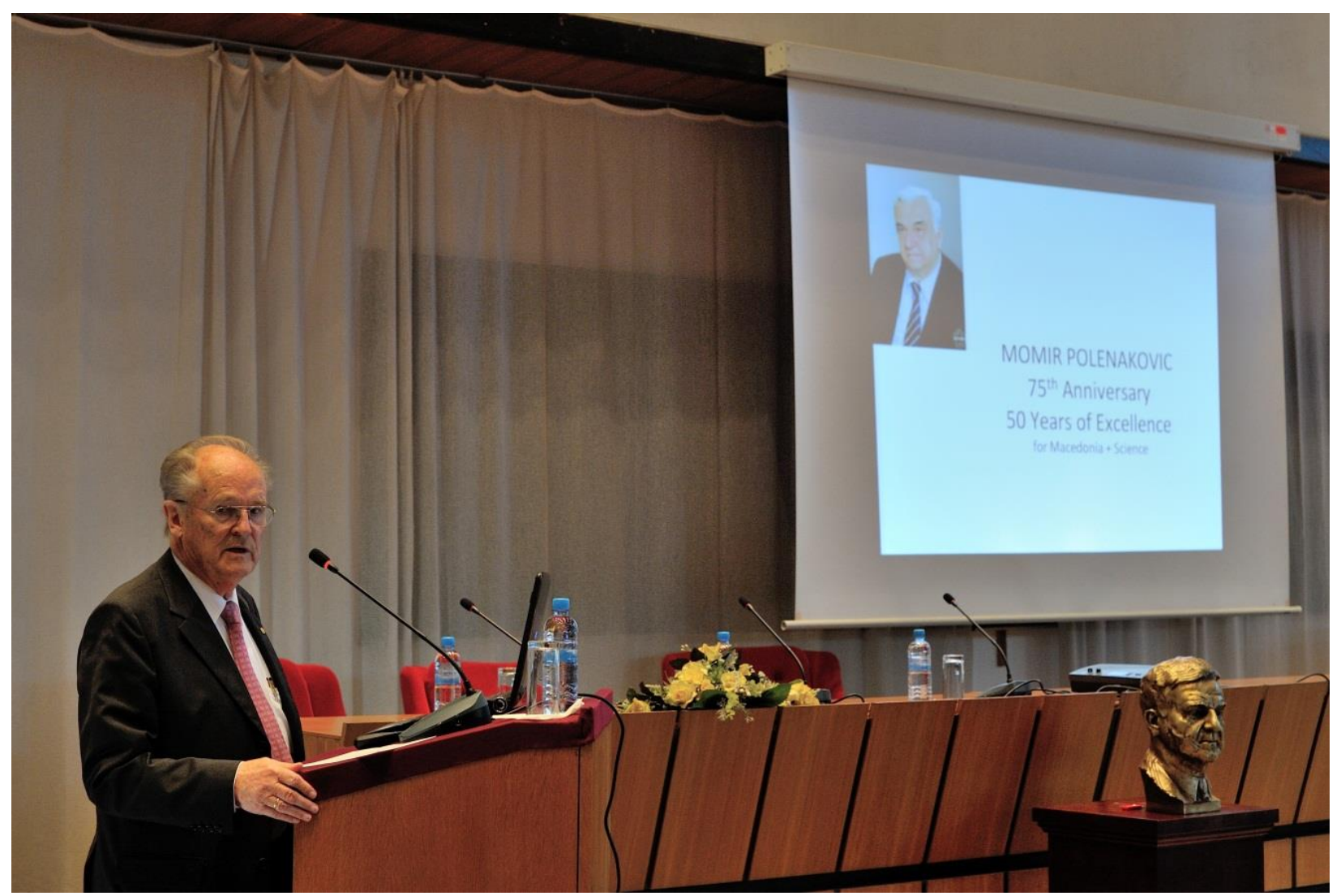

Fig. $58-H$. Klinkmann 
M. Polenakovic actively participates in a number of other activities relating to the work of the societies and the Macedonian Academy of Sciences and Arts and we mentioned some of his most important activities. Having in mind his entire opus as a doctor, clinician, scientist and educator we can say that M. Polenakovic is one of the leading nephrologists and scientists in the Republic of Macedonia and beyond.

Резиме

МОМИР Х. ПОЛЕНАКОВИК์ - ОСНОВАЧ НА НЕФРОЛОШКИТЕ ЗДРУЖЕНИЈА ВО РЕПУБЛИКА МАКЕДОНИЈА

ОФИЦИЈАЛНО ОБРАК'АҢЕ НА ПРОФ. Д-Р ГОЦЕ СПАСОВСКИ, ПРЕТСЕДАТЕЛ НА МАКЕДОНСКОТО ЗДРУЖЕНИЕ ЗА НЕФРОЛОГИЈА, ДИЈАЛИЗА, ТРАНСПЛАНТАЦИЈА И ВЕШТАЧКИ ОРГАНИ (МЗНДТВО), И НА ПРОФ. Д-Р ОЛИВЕРА СТОЈЧЕВАТАНЕВА, ПРОДЕКАНКА НА МЕДИЦИНСКИОТ ФАКУЛТЕТ ВО СКОПЈЕ И ГЕНЕРАЛЕН СЕКРЕТАР НА МЗНДТВО

\section{Гоце Спасовски и Оливера Стојчева-Танева}

Медицински факултет, Универзитет „Св. Кирил и Методиј“, Скопје, Р. Македонија

Акад. Момир Поленаковиќ го посветил својот живот и дело во дијагностика и лекување на бубрежно болните, како и во истражување

\section{REFERENCES}

1. Biography and Bibliography of Acad. Momir Polenakovic http://manu.edu.mk/prilozi/editor.htm.

на бубрежните болести. Големото искуство стекнато во работата со бубрежно болните и посетата на најреномираните нефролошки центри во Европа и светот, тој им го пренел на своите колеги преку работата на медицинските и нефролошките здруженија.

Работата на здруженијата, всушност беше успешна едукација на младите доктори и специјалисти. Меѓу неговите најистакнати позиции, можеме да ги спомнеме: претседател на Македонското лекарско друштво, основач и претседател на МЗНДТВО, претседател на Југословенското нефролошко друштво, основач и претседател на БАНТАО, како и член на одборите на ЕСАО и ЕРА-ЕДТА. Тој има добиено многу признанија за своите работни достигнувања.

Клучни зборови: лекарско здружение, нефролошко здружение 